\title{
Comparison of Current State Residential Energy Codes with the 1992 Model Energy Code for One- and Two-Family Dwellings; 1994
}

\author{
L. A. Klevgard \\ Z. T. Taylor \\ R. G. Lucas
}

Prepared: August 1994

Published: January 1995

Prepared for

the U.S. Department of Energy

under Contract DE-AC06-76RLO 1830

Pacific Northwest Laboratory

Richland, Washington 99352 



\section{DISCLAIMER}

This report was prepared as an account of work sponsored by an agency of the United States Government. Neither the United States Government nor any agency thereof, nor any of their employees, make any warranty, express or implied, or assumes any legal liability or responsibility for the accuracy, completeness, or usefulness of any information, apparatus, product, or process disclosed, or represents that its use would not infringe privately owned rights. Reference herein to any specific commercial product, process, or service by trade name, trademark, manufacturer, or otherwise does not necessarily constitute or imply its endorsement, recommendation, or favoring by the United States Government or any agency thereof. The views and opinions of authors expressed herein do not necessarily state or reflect those of the United States Government or any agency thereof. 


\section{DISCLAIMER}

Portions of this document may be illegible in electronic image products. Images are produced from the best available original document. 


\section{Foreword}

This report is one in a series of documents describing research activities in support of the U.S. Department of Energy (DOE) Building Energy Codes Program. The Pacific Northwest Laboratory (PNL) leads the program for DOE. The goal of the program is to develop and support the adopting, implementation, and enforcement of Federal, State, and Local energy codes for new buildings. Such actions are required of DOE by Title III of the Energy Conservation and Production Act (42 USC 6831 et seq.) as amended by section 101 of the Energy Policy Act of 1992 (EPAct, Public Law 102-486).

The program approach to meeting the goal is to initiate and manage individual research and standards and guidelines development efforts that are plannied and conducted in cooperation with representatives from throughout the buildings community. Projects under way involve practicing architects and engineers, professional societies and code organizations, industry representatives, and researchers from the private sector and national laboratories. Research results and technical justifications for standards criteria are provided to standards development and model code organizations and to Federal, State, and local jurisdictions as a basis to update their codes and standards. This effort helps to ensure that building standards incorporate the latest research results to achieve maximum energy savings in new buildings, yet remain responsive to the needs of the affected professions, organizations, and jurisdictions. Our efforts also support the implementation, deployment, and use of energy-efficient codes and standards.

EPAct establishes the 1992 Model Energy Code (MEC), published by the Council of American Building Officials (CABO 1992a), as the minimum criteria for several energy-related requirements. First, each state is required to "certify to the Secretary that it has reviewed the provisions of its residential building code regarding energy efficiency and made a determination as to whether it is appropriate for such a State to revise such residential building code provisions to meet or exceed CABO Model Energy Code, 1992." Further, the Department of Housing and Urban Development (HUD) and the Department of Agriculture (via the Farmers Home Administration [FmHA]) are required to establish standards for government-assisted housing that "meet or exceed the requirements of the Council of American Building Officials Model Energy Code, 1992..."

This report documents findings from an analysis conducted by PNL of the States' building codes to determine if the codes meet or exceed the 1992 MEC energy efficiency requirements (CABO 1992a).

Readers with questions, comments, or suggestions about this document or the work it describes are encouraged to contact the author(s), program managers, or project managers.

Jeffrey A. Johnson

Building Energy Standards Program

Pacific Northwest Laboratory
Jean J. Boulin

Office of Codes and Standards

U.S. Department of Energy 


\section{Summary}

The Energy Policy Act of 1992 (EPAct, Public Law 102-486) establishes the 1992 Model Energy Code (MEC), published by the Council of American Building Officials (CABO 1992a), as model criteria for several energy-related requirements. First, each State is required to "certify to the Secretary that it has reviewed the provisions of its residential building code regarding energy efficiency and made a determination as to whether it is appropriate for such a State to revise such residential building code provisions to meet or exceed CABO Model Energy Code, 1992." Further, the Department of Housing and Urban Development (HUD) and the Department of Agriculture (via the Farmers Home Administration [FmHA]) are required to establish standards for government-assisted housing that "meet or exceed the requirements of the Council of American Building Officials Model Energy Code, 1992..."

To assist in determining whether existing State codes meet these requirements, the U.S. Department of Energy (DOE) tasked Pacific Northwest Laboratory (PNL) with conducting an analysis to determine if each State's building code meets the 1992 MEC energy efficiency requirements.

This report presents an analysis of State codes in effect as of June 1994. We recognize that actions to adopt and implement new codes are ongoing; thus, this analysis may not reflect the current status of all States. This analysis was limited to thermal envelope and duct provisions applicable to one- and twofamily dwellings. It examines the scope of the codes applicability and assumes $100 \%$ compliance with both the State code and the MEC. While a more detailed analysis of each State code might result in a more rigorous comparison, the approach used in this analysis is valid within the set of assumptions chosen.

A simple methodology was used for comparing the disparate State codes with the $1992 \mathrm{MEC}$. Each State code was measured against a series of criteria to determine if it meets or exceeds the energy requirements of the $1992 \mathrm{MEC}$. The criteria were designed to accommodate the numerous State code formats but avoid substantial effort in designing a unique evaluation methodology for each code. This report has been published in large part to give the States a chance to review this analysis.

Seven (7) of the 50 States have no State code, and therefore fail to meet or exceed the 1992 MEC energy requirements. Of the 43 remaining States, five (5) States have separate code requirements for electrically-heated houses and for houses using other heating fuels. Thus, we considered these five States as each having two separate codes. The compliance determinations for technical provisions of these 48 individual codes (without regard to the degree the States enforce the requirements) are as follows:

- Twenty six (26) State codes unambiguously do not meet or exceed the 1992 MEC.

- Two (2) State codes marginally do not meet or exceed the 1992 MEC.

- Seventeen (17) State codes unambiguously meet or exceed the $1992 \mathrm{MEC}$. 
- Two (2) State codes marginally meet or exceed the 1992 MEC.

- One (1) State code could not be categorized with our methodology.

State codes labelled as "marginally" passing or failing have $U_{0}$ values close (within $\pm 5 \%$ ) to those implied by the 1992 MEC. Table S.1 summarizes our determination of State code compliance with the 1992 MEC.

Some of the 19 State codes with technical provisions that meet or exceed the 1992 MEC (either unambiguously or marginally) are not mandatory for all new construction. We reviewed these State codes to determine their scope of applicability. For HUD's purposes, approval of subsidized or guaranteed financing may depend only on a particular house's compliance with the State code. Table S. 2 provides a summary of these State codes' scope. This summary does not address the degree of State enforcement of these code requirements. The shaded States in Figure S.1 are those in which the State code meets or exceeds the 1992 MEC for all fuels and is applicable to all new one- and two-family dwellings.

This analysis may be used in a number of ways. First, the results may be used to help States certify to DOE whether it is appropriate to revise their residential building code requirements for one- and twofamily dwellings. It is important to recognize that States codes are not required to meet or exceed the MEC, the States are just required to make the determination whether or not they do. It is allowable for a State to perform its own analysis and disagree with the findings of this analysis. Secondly, the code analysis methodology may be used for future code evaluations. Finally, the results may be used by HUD and FmHA determine whether homes built to the various State codes meet the 1992 MEC and thus qualify for subsidized or guaranteed financing. 
Table S.1. Summary of Compliance of State Codes' Technical Provisions with 1992 MEC

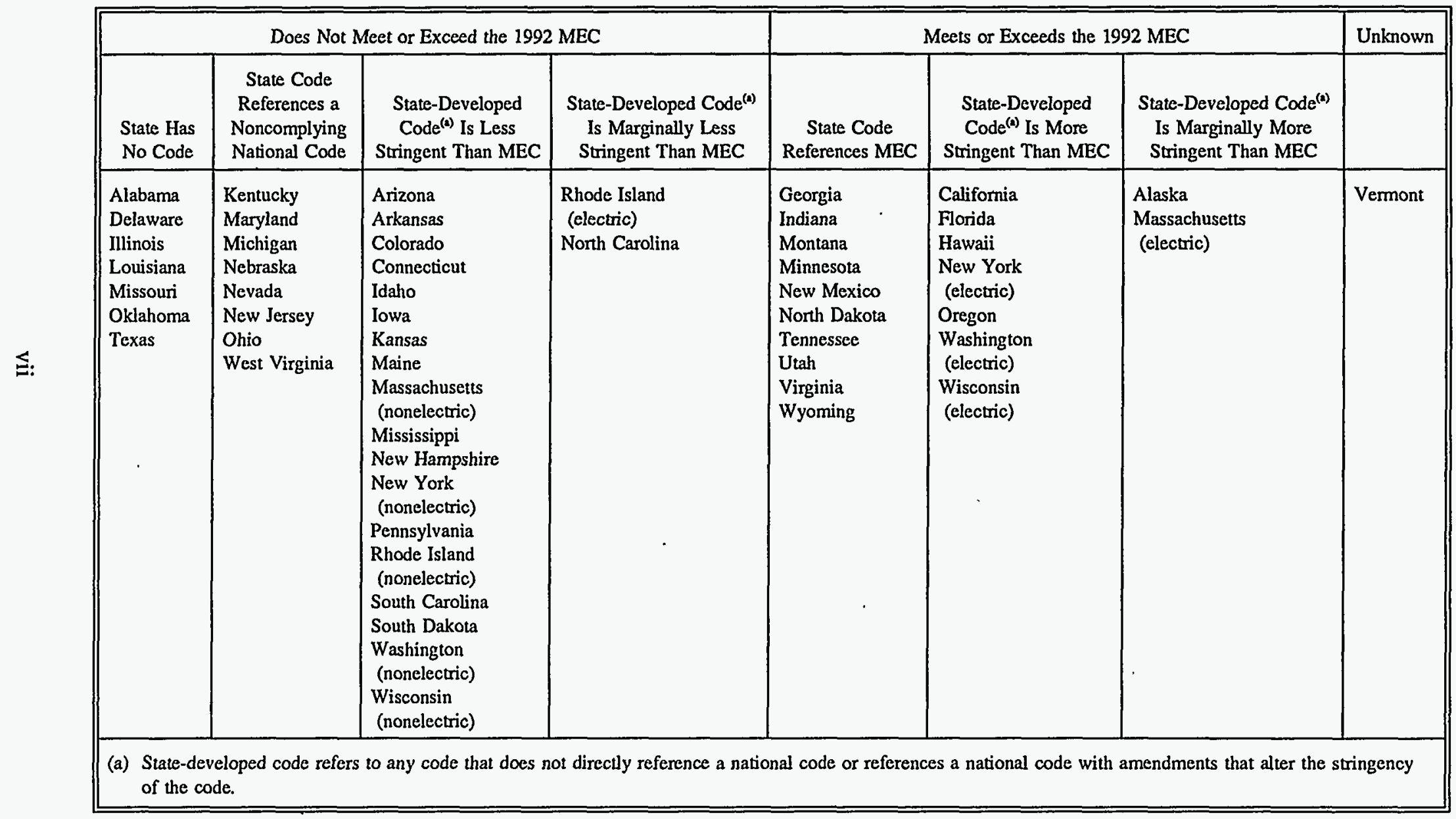


Table S.2. Scope of State Codes That Meet or Exceed the 1992 MEC

\begin{tabular}{|c|c|c|}
\hline & Limited Scope & $\begin{array}{l}\text { Mandatory for ALL One- and Two- } \\
\text { Family Dwellings }\end{array}$ \\
\hline & $\begin{array}{c}\text { Alaska }^{(\mathrm{a})} \\
\text { Hawaii }^{(\mathrm{b})} \\
\text { North Dakota }^{(\mathrm{c})} \\
\text { Wyoming }^{(\mathfrak{b})}\end{array}$ & $\begin{array}{c}\text { California } \\
\text { Florida } \\
\text { Georgia } \\
\text { Indiana } \\
\text { Massachusetts }^{(\mathrm{d})} \\
\text { Minnesota } \\
\text { Montana } \\
\text { New Mexico } \\
\text { New York } \\
\text { Oregon } \\
\text { Tennessee } \\
\text { Utah } \\
\text { Virginia }^{(\mathrm{d})} \\
\text { Washington }^{(\mathrm{d})} \\
\text { Wisconsin }^{(\mathrm{d})}\end{array}$ \\
\hline $\begin{array}{l}\text { (b) } \\
\text { (c) } \\
\text { (d) }\end{array}$ & \multicolumn{2}{|c|}{$\begin{array}{l}\text { The Alaska code is mandatory only for housing financed } \\
\text { by the Alaska Housing Finance Corporation, accounting } \\
\text { for approximately } 10 \% \text { of the new residential } \\
\text { construction in Alaska. } \\
\text { The code is not mandatory. } \\
\text { The code is mandatory only for municipalities that have } \\
\text { adopted it. } \\
\text { The code meets or exceeds the } 1992 \text { MEC for only } \\
\text { electrically-heated homes. }\end{array}$} \\
\hline
\end{tabular}




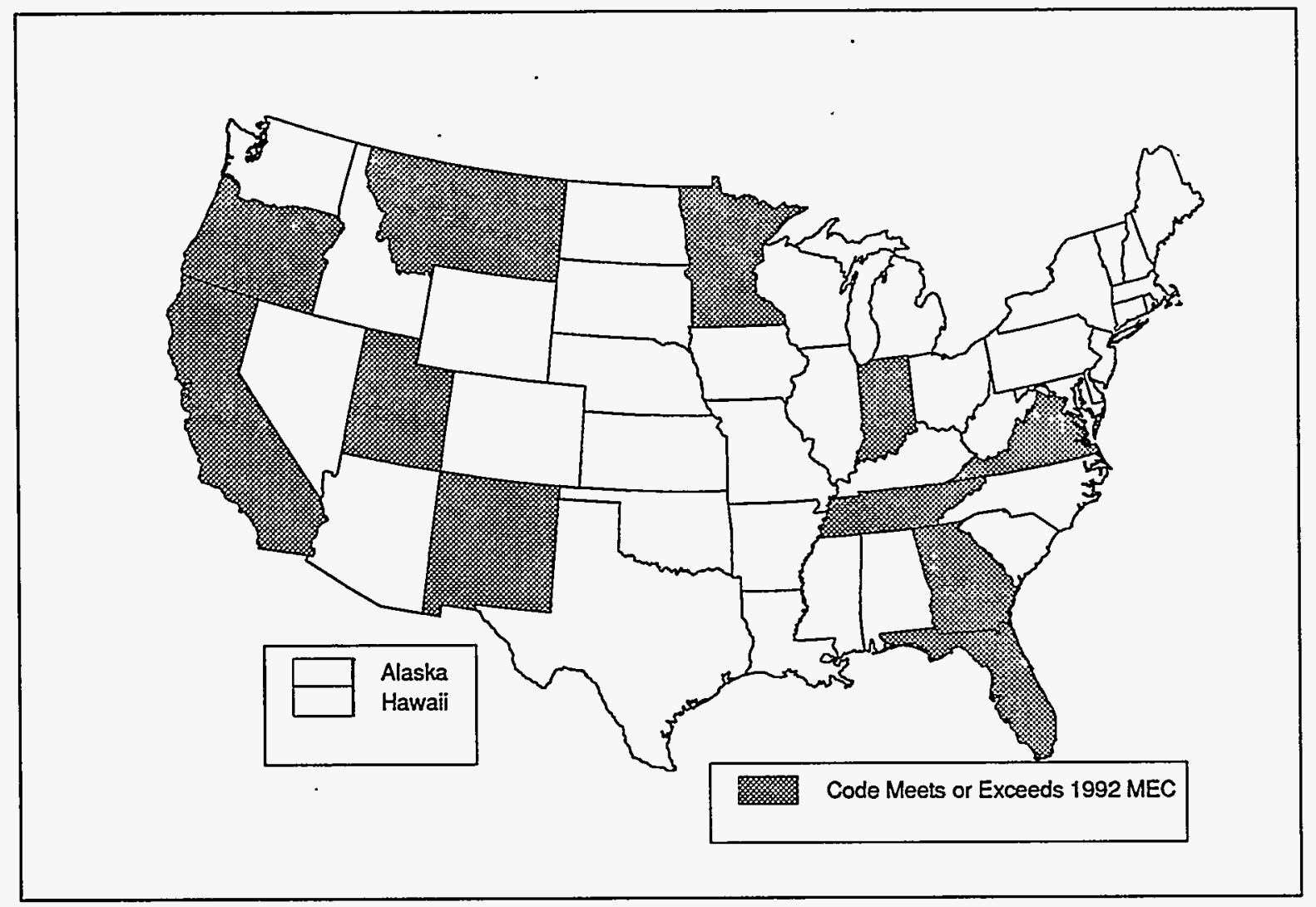

Figure S.1. States with Codes That Fully Meet or Exceed the 1992 MEC and Apply to All New One- and Two-Family Dwellings 
. 


\section{Contents}

Foreword $\ldots \ldots \ldots \ldots \ldots \ldots \ldots \ldots \ldots \ldots \ldots \ldots \ldots \ldots \ldots \ldots \ldots \ldots \ldots \ldots \ldots \ldots \ldots \ldots \ldots$

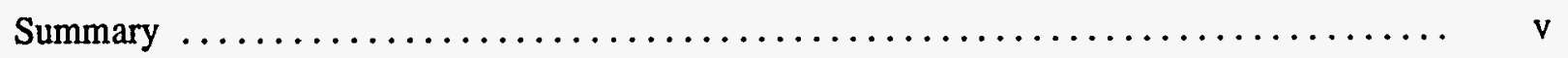

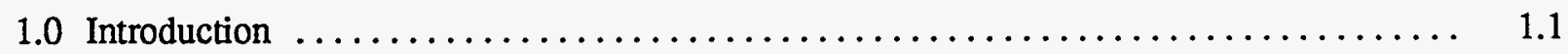

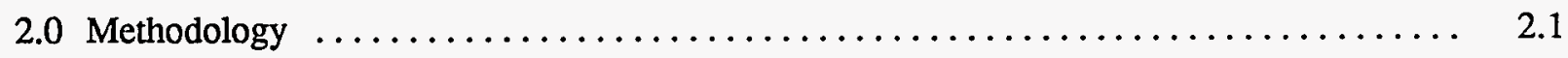

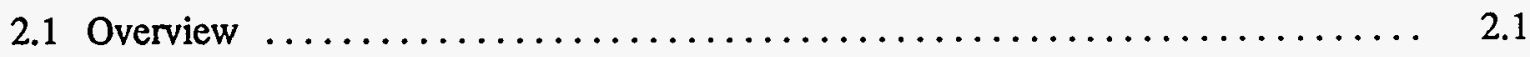

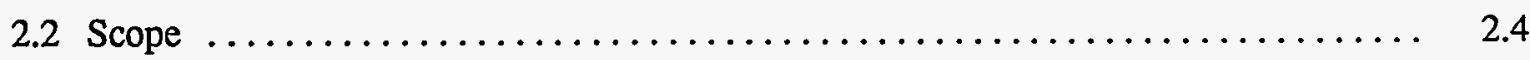

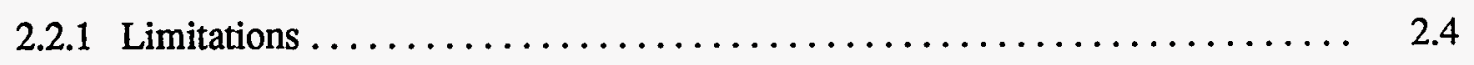

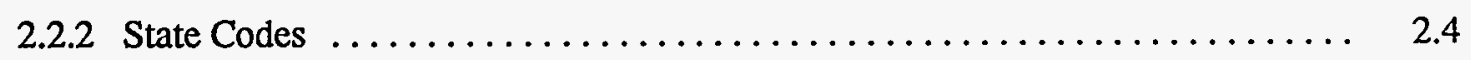

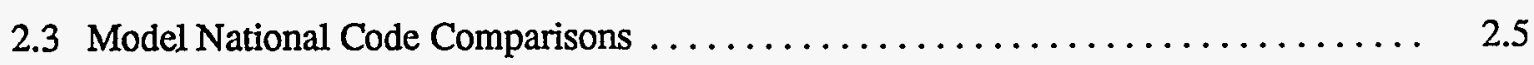

2.4 Component-By-Component Comparisons $\ldots \ldots \ldots \ldots \ldots \ldots \ldots \ldots \ldots \ldots \ldots \ldots \ldots \ldots \ldots \ldots$

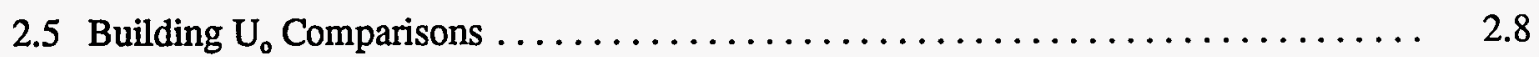

2.5.1 Defining Prototype House for Comparison $\ldots \ldots \ldots \ldots \ldots \ldots \ldots \ldots \ldots$

2.5.2 Defining Default Code Requirements $\ldots \ldots \ldots \ldots \ldots \ldots \ldots \ldots \ldots \ldots$

2.5.3 Calculating Envelope Component U-Values and F-Values $\ldots \ldots \ldots \ldots \ldots \ldots$

2.5.4 Calculating Average Overall House $U$-Values $\left(U_{0}\right) \ldots \ldots \ldots \ldots \ldots \ldots$

2.5.5 Calculating State Average $U-$ Values $\ldots \ldots \ldots \ldots \ldots \ldots \ldots \ldots \ldots \ldots \ldots \ldots \ldots \ldots \ldots$

2.5 .6 Calculating Foundation Average $U_{0} \ldots \ldots \ldots \ldots \ldots \ldots \ldots \ldots \ldots \ldots \ldots \ldots \ldots \ldots$

2.5.7 Comparing Average $\mathrm{U}_{\mathrm{o}} \ldots \ldots \ldots \ldots \ldots \ldots \ldots \ldots \ldots \ldots \ldots \ldots \ldots \ldots \ldots \ldots \ldots \ldots$

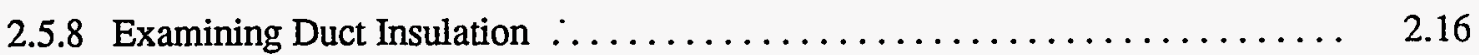

2.5.9 Example of U-Value Calculation $\ldots \ldots \ldots \ldots \ldots \ldots \ldots \ldots \ldots \ldots \ldots \ldots \ldots \ldots$

2.5.10 State Codes with Unusual Provisions $\ldots \ldots \ldots \ldots \ldots \ldots \ldots \ldots \ldots \ldots \ldots \ldots \ldots \ldots$

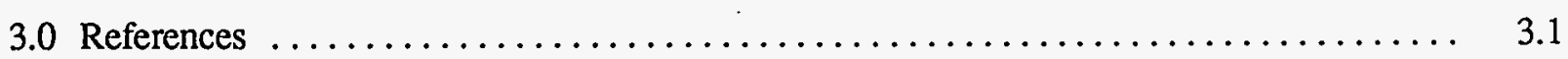


Appendix A - State Residential Energy Codes

A. 1

Appendix B - Envelope Component U-Value Calculations .

B.1 


\section{Figures}

S.1 States with Codes That Fully Meet or Exceed the 1992 MEC and Apply to All New One- and Two-Family Dwellings

2.1 Flowchart of Criteria Used to Determine State Code Compliance with the 1992 MEC . . . . . . . . . . . . . . . . . . . . . . . . . . . . . . . . . . 2.2

2.2 Comparison of ANSI/ASHRAE/IES Standard 90A-1980 and 1992 MEC Ceiling U-Values 2.6

2.3 Comparison of ANSI/ASHRAE/IES Standard 90A-1980 and 1992 MEC Wall U-Values .. 2.6

2.4 Comparison of ANSI/ASHRAE/IES Standard 90A-1980 and 1992 MEC Floor U。 for Homes with Floors Over Unheated Spaces $\ldots \ldots \ldots \ldots \ldots \ldots \ldots \ldots \ldots \ldots \ldots \ldots \ldots \ldots \ldots$

2.5 Comparison of ANSI/ASHRAEIIES Standard 90A-1980 and 1992 MEC U Requirements

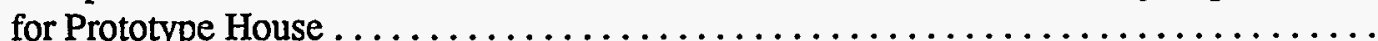

\section{Tables}

S.1 Summary of Compliance of State Codes' Technical

Provisions with 1992 MEC

vii

S.2 Scope of State Codes That Meet or Exceed the 1992 MEC ............... viii

2.1 Prototype Dimensions Used for $U_{0}$ Calculations $\ldots \ldots \ldots \ldots \ldots \ldots \ldots \ldots \ldots \ldots$

2.2 Foundation Wall F-Values $\ldots \ldots \ldots \ldots \ldots \ldots \ldots \ldots \ldots \ldots \ldots \ldots \ldots \ldots \ldots \ldots \ldots \ldots \ldots \ldots \ldots \ldots$

2.3 Coefficients for Foundation Wall F-Value Equation $\ldots \ldots \ldots \ldots \ldots \ldots \ldots \ldots \ldots \ldots \ldots \ldots$

2.4 Designing Information and Housing Starts for Washington Cities $\ldots \ldots \ldots \ldots \ldots$

2.5 Washington Nonelectric Code R-Value Requirements $\ldots \ldots \ldots \ldots \ldots \ldots \ldots \ldots \ldots$

2.6 MEC Envelope Component Requirements for Washington $\ldots \ldots \ldots \ldots \ldots \ldots \ldots \ldots \ldots$

2.7 Washington Nonelectric Code U-Value and F-Value Requirements $\ldots \ldots \ldots \ldots \ldots \ldots$

2.8 Washington Nonelectric Code and the $1992 \mathrm{MEC}_{\mathrm{o}} \mathrm{s}$ by Foundation Type $\ldots \ldots \ldots 2.23$

2.9 Average Envelope $U_{0} s$ by Foundation Type for Washington Nonelectric Code and the $1992 \mathrm{MEC}$ 
2.10 Average Overall Envelope U-Values for Washington Nonelectric Code and the 1992 MEC 


\subsection{Introduction}

The Energy Policy Act of 1992 (EPAct, Public Law 102-486) establishes the 1992 Model Energy Code (MEC), published by the Council of American Building Officials (CABO 1992a), as minimum criteria for several energy-related requirements. First, each state is required to "certify to the Secretary that it has reviewed the provisions of its residential building code regarding energy efficiency and made a determination as to whether it is appropriate for such a State to revise such residential building code provisions to meet or exceed CABO Model Energy Code, 1992." Further, the Department of Housing and Urban Development (HUD) and the Department of Agriculture (via the Farmers Home Administration [FmHA]) are required to establish standards for government-assisted housing that "meet or exceed the requirements of the Council of American Building Officials Model Energy Code, 1992..."

To assist in determining whether existing state codes meet these requirements, the U.S. Department of Energy (DOE) tasked Pacific Northwest Laboratory (PNL) ${ }^{(a)}$ with conducting an analysis to determine if each state's building code meets or exceeds the 1992 MEC energy efficiency requirement

EPAct requires each state to review the provisions of its residential building code and commercial building code regarding energy efficiency. The terms residential and commercial are not defined in EPAct. A U.S. DOE notice on updating state building codes regarding energy efficiency (94 FR 17259) provides guidance in defining residential and commercial buildings as follows:

"...high-rise multi-family residential buildings (greater than three stories) and hotel, motel, and other transient residential building types of any height have historically been treated for energy code purposes as commercial buildings. Consistent with the treatment of high-rise multi-family residential buildings and hotels, motels, and other transient residential building types in (ASHRAE/IES) Standard 90.1-1989 as if they were commercial buildings, the Department (U.S. DOE) is of the view that the energy efficiency requirements of building codes applicable to such buildings should be reviewed and updated by the States and units of general purpose local government pursuant to the Act as if they were commercial building code requirements. Consequently, residential buildings, for the purposes of certification, would include one- and two-family detached and attached buildings, townhouses, row houses, and low-rise multi-family buildings (not greater than three stories) such as condominiums and. garden apartments."

This report is limited to a comparison of one- and two-family dwellings only. It does not cover townhouses, row houses, or low-rise multi-family buildings.

We used a simple methodology for comparing the disparate state codes with the 1992 MEC. Each state code was measured against a series of criteria to determine if it meets or exceeds the energy efficiency requirements of the $1992 \mathrm{MEC}$. The criteria were designed to accommodate the numerous

(a) PNL is a multiprogram national laboratory operated for the U.S. Department of Energy under Contract DE-AC06-76RLO 1830 by Battelle Memorial Institute. 
state code formats but avoid substantial effort in designing a unique evaluation methodology for each code.

This report describes our analysis of the states' building energy codes. ${ }^{(a)}$ In Section 2.0 of this report, the methodology used to compare the state codes with the $1992 \mathrm{MEC}$ is described. Section 3.0 lists documents referenced in this report. Appendix A contains a summary of our findings and compliance determination for each state. Appendix B describes the assumptions and calculations used to determine thermal conductances.

(a) "Building energy code" generically includes legislation, regulations, codes, ordinances, standards, statutes, etc. that establish legal minimum energy-related requirements for building design and construction. 


\subsection{Methodology}

\subsection{Overview}

The comparison of state energy codes with the 1992 MEC energy efficiency requirements is not straightforward because of the variety of codes involved and the differences in the way their requirements are expressed. The 1992 MEC expresses its provisions for thermal integrity of the building envelope in terms of maximum allowable $U$-values for various building components. Other codes may express requirements as nominal $R$-values, overall building $U$-values $\left(U_{0}{ }^{(a)}\right)$, maximum allowable energy use per conditioned square foot, or some other criterion. Some codes are not readily reduced to simple criteria, requiring somewhat complex calculations for the comparison.

Each state code was measured against a series of criteria to determine if it meets or exceeds the energy efficiency requirements of the $1992 \mathrm{MEC}$. The criteria were designed to accommodate the variety of state code formats but avoid substantial effort in designing a unique evaluation methodology for each code. The first three steps in the series identified state codes that obviously meet or do not meet the 1992 MEC requirements because they have no code at all, directly reference the 1992 MEC or a complying national code, or reference a noncomplying code. The remaining state codes were measured against additional criteria involving more detailed comparisons to determine compliance. The fourth step compared state code provisions with 1992 MEC provisions on a component-by-component basis. For state codes that could not be compared component-by-component, overall building U-values implied by the state code were compared with those implied by the 1992 MEC. Figure 2.1 displays a flowchart of these steps.

All steps in our comparison explicitly assumed that the heating, ventilating, and air-conditioning (HVAC) efficiency requirements established by the National Appliance Energy Conservation Act (NAECA) of 1987 (42 USC 6201 et seq.), which establishes mandatory national minimum efficiency requirements for heating and cooling equipment, are applicable in all situations. ${ }^{(b)}$ Any HVAC efficiency requirements in the state codes, as well as the HVAC provisions of the $1992 \mathrm{MEC}$, are assumed to be preempted by NAECA.

The criteria used to evaluate the state codes are described below. "Pass" implies that the state's code results in an average one- or two-family dwelling that meets or exceeds the 1992 MEC. "Fail" implies that the state's code does not meet or exceed the 1992 MEC.

(a) The MEC defines $U_{o}$ as an overall building component $U$-value, such as a wall $U_{0}$. This definition is contrary to the convention where $U_{o}$ is the overall building $U$-value. In this report, $U_{0}$ will always refer to the overall building U-value.

(b) NAECA does not apply to some equipment used in residential structures. However, the HVAC equipment not covered by NAECA are rare in one- and two-family structures. 


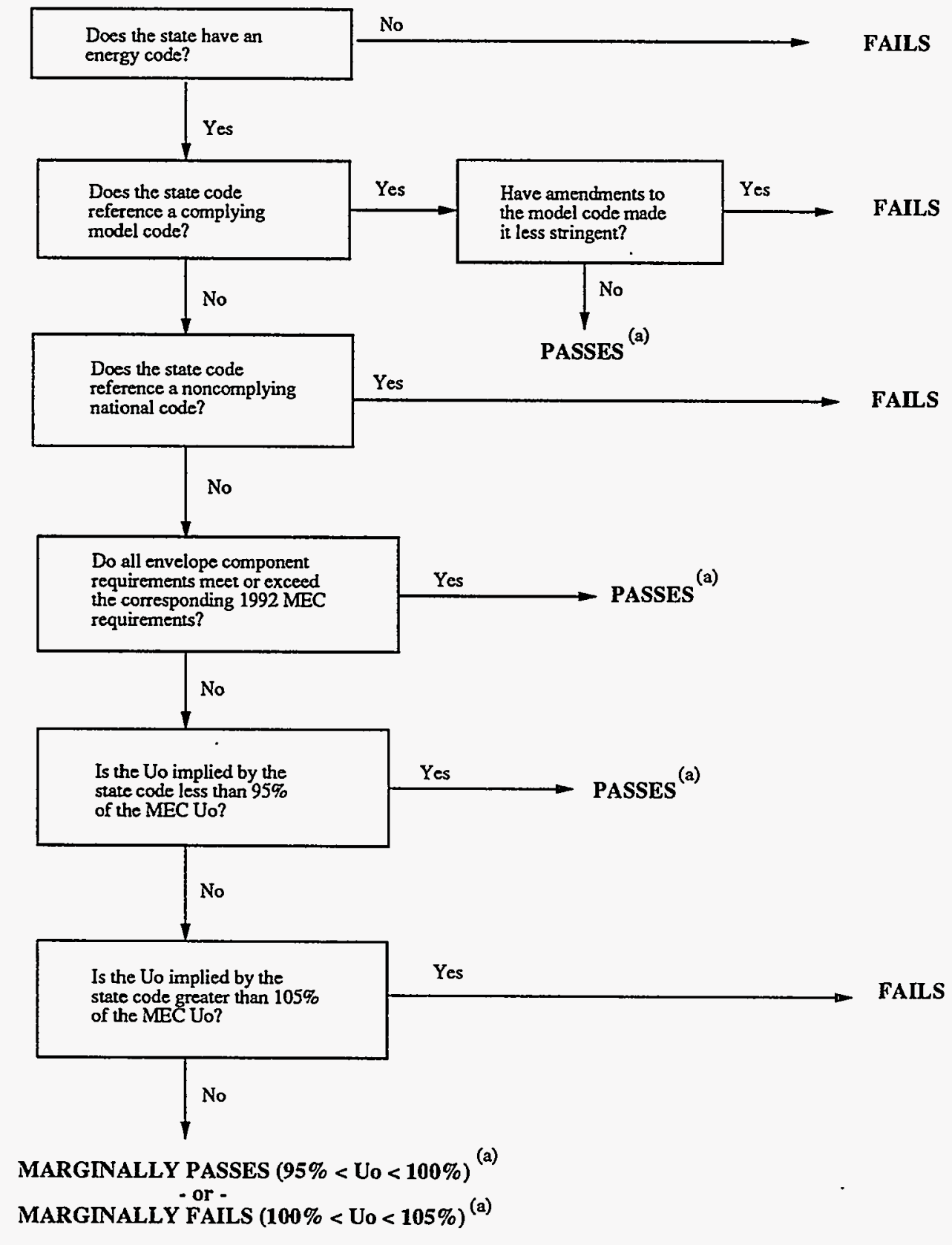

(a) Duct requirements are also reviewed.

Figure 2.1. Flowchart of Criteria Used to Determine State Code Compliance with the 1992 MEC 
The following steps were conducted:

1. If the state does not have an energy code, it fails.

2. If the state code directly references the $1989 \mathrm{MEC}$ (CABO 1989), $1992 \mathrm{MEC}$ (CABO 1992a), or 1993 MEC (CABO 1993), it passes. Previous editions of the MEC are significantly less energyefficient. If the state code is based on the 1989,1992 , or $1993 \mathrm{MEC}$, but the state has made amendments upon adoption that make the requirements less stringent, the code fails.

3. If the state code references a model national energy code that is known to be less stringent than the 1992 MEC, the state code fails. Model national codes that fail to meet or exceed the 1992 MEC are the Building Officials and Code Administrators International, Inc. (BOCA) National Building Code, the Southern Building Code Congress International, Inc. (SBCCI) Standard Building Code, versions of the MEC prior to 1989, and any other codes based on ANSI/ASHRAE/IES Standard 90A-1980 (ASHRAE 1980) (or earlier versions). For a further discussion, see Section 2.3.)

4. If ALL component ${ }^{(a)}$ requirements of the state code are at least as stringent as the corresponding 1992 MEC requirement, the state code passes.

5. If the $\mathrm{U}_{0}$ implied by the state code is less than that implied by the $1992 \mathrm{MEC}$, the state code passes.

6. If the $\mathrm{U}_{0}$ implied by the state code is greater than that implied by the $1992 \mathrm{MEC}$, the state code fails.

The criteria used to evaluate the state codes provided a preliminary determination as to whether the technical provisions of a state code meet or exceed those of the $1992 \mathrm{MEC}$. However, the following two final steps were applied to some of the codes: We reexamined any state code that (1) failed, marginally failed, or marginally passed for unique characteristics (e.g., solar/shading provisions) that might compensate for the code's U-value inadequacies and (2) passed or marginally failed for duct insulation requirements.

(a) We considered U-values of the following components: window, ceiling, wall, floor over crawl space, basement wall, and slab edge. 


\subsection{Scope}

\subsubsection{Limitations}

Our analysis was limited to one- and two-family dwellings. We considered any legislation, regulations, codes, ordinances, standards, statutes, etc. that establish legal minimum energy-related requirements for building design and construction. We did not examine state-owned building codes or unique local (county, municipal) codes.

Some of the state codes we examined are not mandatory, but often have force of law when adopted by local jurisdictions. We examined the mandatory codes without regard to the state's current enforcement procedures; i.e., we examined only the technical content of the codes and the scope of their applicability. We did not examine whether each state has sufficient enforcement or other incentive mechanisms to ensure widespread compliance with its code.

We examined only code provisions related to the thermal envelope. Other code requirements, including pipe insulation, window shading coefficients, building orientations, equipment oversizing limits, and low-flow showerheads, were ignored. These requirements are assumed to have a smaller impact on the energy consumption of the building than requirements for the thermal envelope, ducts, and heating and cooling equipment. Also, the impact of these requirements on the energy consumption of a building is more difficult to quantify. Air infiltration control requirements were not examined because infiltration is largely dependent on the quality of construction. Furthermore, infiltration requirements are often vague and very difficult to enforce.

For most building components, we evaluated only the most common, on a nation-wide basis, construction type. We ignored code provisions for vaulted ceilings, concrete and other thermally-massive walls, crawl space walls, and heated slabs.

\subsubsection{State Codes}

Many of the state energy codes simply reference an existing model national code. Other state codes are the result of dedicated efforts to create a unique code specifically designed for that state. The majority of the state energy codes lie somewhere in between these extremes, with the state amending or revising a model national code in some way. The model national codes--the BOCA National Building Code, SBCCI Standard Building Code, International Conference of Building Officials (ICBO) Uniform Building Code, and the CABO Model Energy Code--all establish thermal envelope requirements that vary by climate (heating degree-days [HDDs]). Many states adopt by reference a national model code and/or create a set of prescriptive R-value requirements (deemed equivalent to the model code) applicable for the whole 
state. Almost all of the wholly state-developed codes also present one or more sets of prescriptive Rvalue requirements, which may be used for compliance.

Some state codes contain multiple prescriptive compliance alternatives, meaning that more than one set of prescriptive requirements or multiple compliance methods (e.g., point systems or household energy calculations) are given. We assumed all paths are equivalent and examined only the primary prescriptive path or the prescriptive path most readily utilized by our methodology. We did, however, evaluate alternative prescriptive paths developed by states as an interpretation of a complying model code. For example, some state codes adopt the 1992 MEC but also provide a list of prescriptive requirements deemed equivalent to the $1992 \mathrm{MEC}$. In those cases, we evaluated the prescriptive requirements.

Some states codes have requirements that differ for different fuel types. In such cases, we examined the various fuel types separately.

\subsection{Model National Code Comparisons}

In our comparison, we considered any state code to meet or exceed the $1992 \mathrm{MEC}$ if it adopts by reference either the $1992 \mathrm{MEC}$ or, because its energy criteria are nearly identical, the $1989 \mathrm{MEC}$ (CABO 1989). There are a few exceptions for states that have amended the 1989 or 1992 MEC to lower the stringency or provide other alternatives to compliance that are not as stringent as the 1992 MEC. States that reference the 1991 (or later edition) ICBO Uniform Building Code with Appendix, Chapter 53 (ICBO 1991) or Appendix, Chapter 13 (ICBO 1994) or the 1992 CABO one- and two-family dwelling code (CABO 1992b) (which both adopt the MEC) also comply.

The 1993 MEC (CABO 1993) envelope requirements for one- and two-family dwellings are slightly more stringent for walls and ceilings for cities with heating degree-days less than 2500 . The $1993 \mathrm{MEC}$ duct requirements are less stringent than the $1992 \mathrm{MEC}$ requirements. The difference in duct requirements was examined using the methodology described in Section 2.5.8. The results indicate that duct requirements do not result in significantly different energy consumption. Therefore, states adopting the 1993 MEC are considered to meet the 1992 MEC.

Any state code that references one of the following model national codes does not comply with the EPAct requirements: 1) the BOCA National Building Code, 2) the SBCCI Standard Building Code, or 3) editions of the MEC prior to 1989. Each of these model codes is based on, or allows, the provisions of ANSI/ASHRAE/IES Standard 90A-1980 (ASHRAE 1980) (or an earlier, less stringent version). A component-by-component comparison of the thermal envelope criteria in ASHRAE (1980) to those in the 1992 MEC clearly demonstrates the ASHRAE (1980) criteria are less stringent. Figures 2.2 through 2.4 show these comparisons for several components as presented in the codes. When examining the Uvalues, consider that a lower $U$-value implies a higher level of insulation. Figure 2.5 shows a comparison of whole-building $U_{0}$ requirements for the prototype house used in this report. 


\section{Roof/Ceiling U-Values}

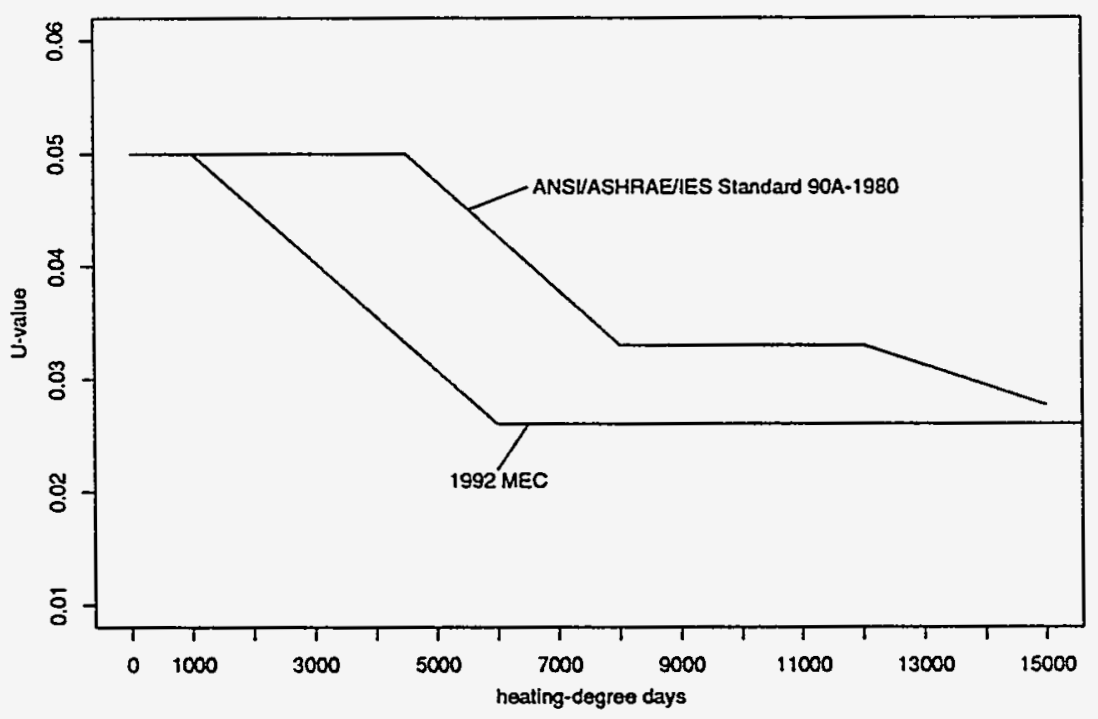

Figure 2.2. Comparison of ANSI/ASHRAE/IES Standard $90 A-1980$ and 1992 MEC Ceiling U-Values

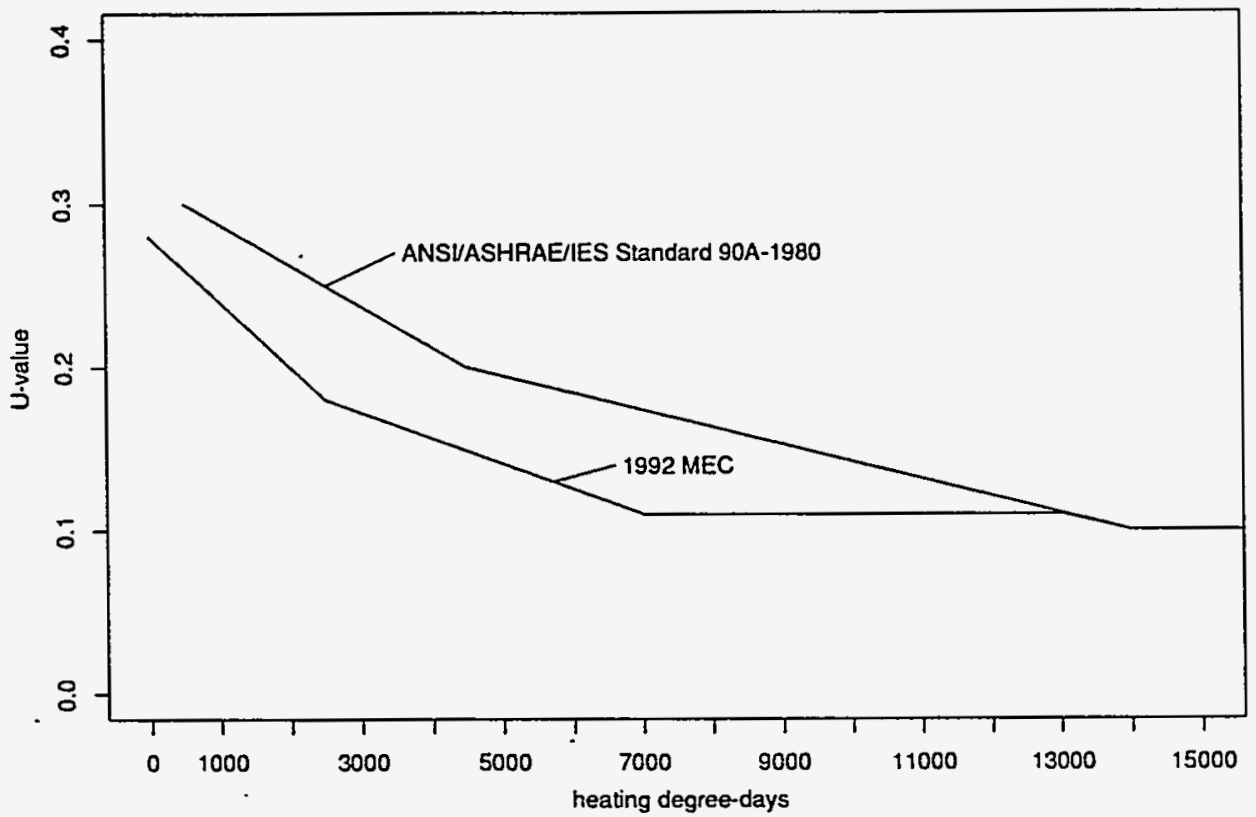

Figure 2.3. Comparison of ANSI/ASHRAE/IES Standard 90A-1980 and 1992 MEC Wall U-Values 


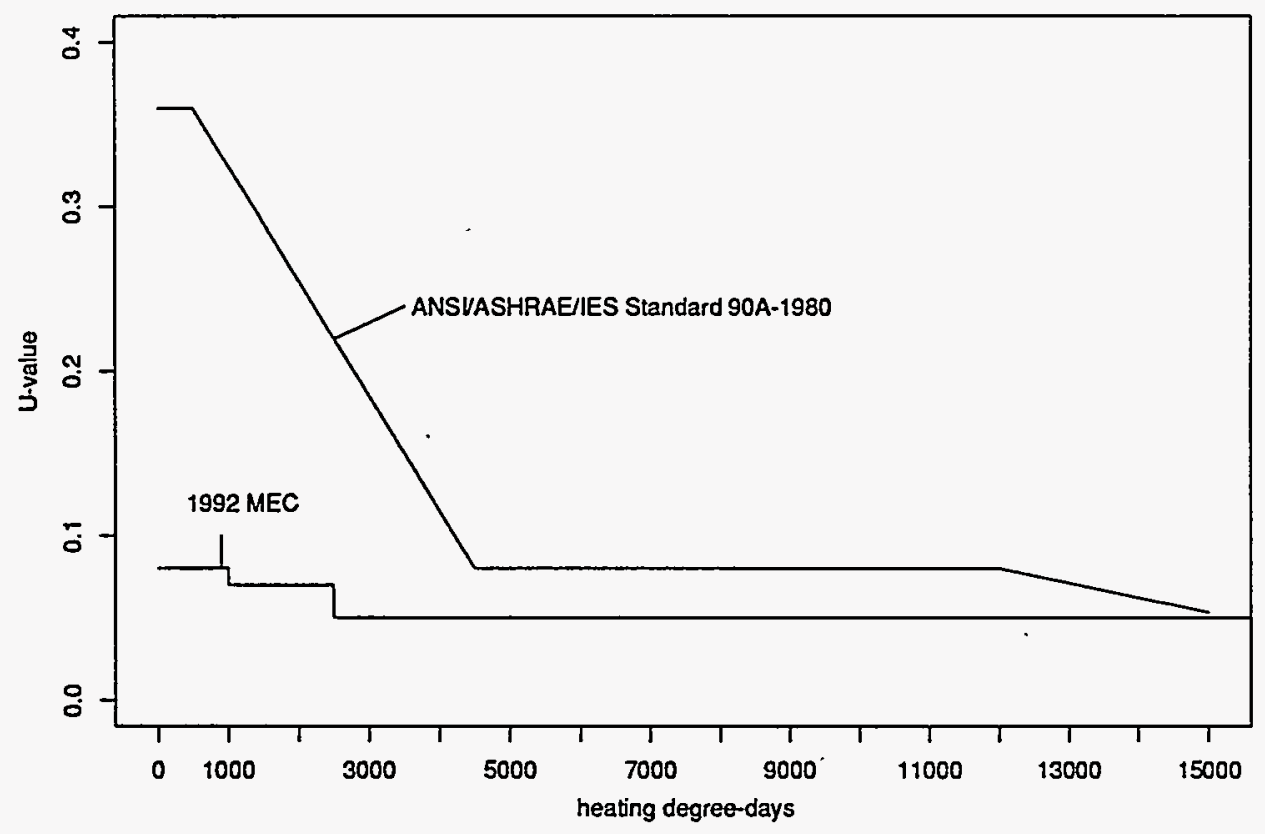

Figure 2.4. Comparison of ANSI/ASHRAE/IES Standard 90A-1980 and 1992 MEC Floor U。 for Homes with Floors Over Unheated Spaces

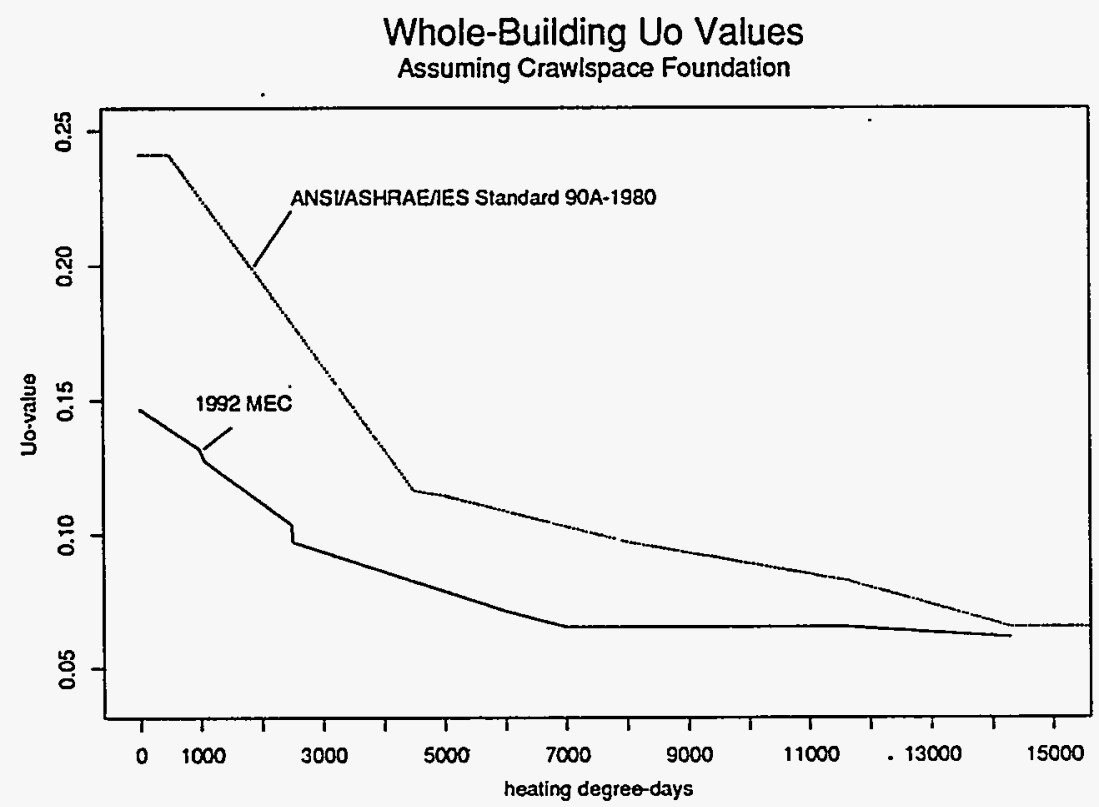

Figure 2.5. Comparison of ANSI/ASHRAEIIES Standard 90A-1980 and $1992 \mathrm{MEC} \mathrm{U}$ Requirements for Prototype House 


\subsection{Component-By-Component Comparisons}

State codes with applicable formats were subjected to a component-by-component comparison with the 1992 MEC. If U-value provisions for each individual component (e.g., ceilings, walls, windows) meet or exceed the corresponding $1992 \mathrm{MEC}$ provisions in all geographical regions of the state, the state code passes. If provisions for every component fail to meet the corresponding provisions of the 1992 MEC in all geographical regions of the state, the code fails. If provisions for some components pass and provisions for others fail, the code was evaluated by a building $U_{0}$ comparison (see Section 2.5 ).

\subsection{Building $\mathrm{U}_{\mathrm{o}}$ Comparisons}

Most state codes did not lend themselves to a component-by-component comparison for two reasons. First, because state codes are generally given in terms of a single set of prescriptive envelope requirements, these requirements were often less stringent than the $1992 \mathrm{MEC}$ in some areas of the state and . more stringent in other areas. To compare these codes, an averaging of requirements across the state was necessary. Second, one envelope requirement was often more stringent than the MEC while another was less stringent. These state codes were compared on an overall envelope $U$-value $\left(U_{0}\right)$ basis.

\subsubsection{Defining Prototype House for Comparison}

For codes that required a $U_{0}$ comparison (could not be compared component-by-component because of format differences), we based the $U_{0}$ calculation on the dimensions of a prototype house designed to approximate the average new single-family home. As discussed in Conner and Lucas (1993), new singlefamily homes built in 1991 averaged $1890 \mathrm{ft}^{2}$ of conditioned floor area and roughly half were one-story (48\%) and half were two-story (47\%) structures, not including basement area. Therefore, our prototype home's envelope component surface areas were determined by averaging those of a $30-\mathrm{ft}$ by $63-\mathrm{ft}$ onestory prototype and a $27-\mathrm{ft}$ by 35 - $\mathrm{ft}$ two-story prototype (both of which have a floor area of $1890 \mathrm{ft}^{2}$ ). Eight-foot-high ceilings were assumed. A total door area of $56 \mathrm{ft}^{2}$ (roughly three doors) was used (Johnson 1987). The prototype dimensions are listed in Table 2.1.

Windows have much higher U-values than opaque walls. Therefore, the amount of window area has a major effect on the gross wall U-value. Obtaining data on window area in new single-family housing was difficult. An older source reported a national average window area equal to $10.3 \%$ of floor area in 1980 (NAHB 1991). One source indicated a national average window area of about $12 \%$ of the floor area (Johnson 1987). The most current published source we could identify reported an estimated average of $410 \mathrm{ft}^{2}$ of flat glass sold per new house (AAMA 1992). Note that this is the area for the glass, not the window; double-pane glazing requires twice the glass needed for single-pane glazing. In a personal communication, Eric Mundy of the Freedonia Group updated this value for PNL for 1992. He estimated that the average for 1992 was $430 \mathrm{ft}^{2}$ per residence. Accounting for double-pane windows, storm windows, and storm doors (AAMA 1992), we estimated an average of about $220 \mathrm{ft}^{2}$ of window area in new houses. This window area corresponds to a window area of roughly $11 \%$ to $12 \%$ of the floor area for our 
Table 2.1. Prototype Dimensions Used for $U_{0}$ Calculations

\begin{tabular}{|l|c|}
\hline \multicolumn{1}{|c|}{ Envelope Component } & Area or Length \\
\hline Ceiling & $1418 \mathrm{ft}^{2}$ \\
\hline Gross Wall & $1736 \mathrm{ft}^{2}$ \\
\hline Basement Wall & $1240 \mathrm{ft}^{2}$ \\
\hline Conditioned Floor & $1890 \mathrm{ft}^{2}$ \\
\hline Door & $56 \mathrm{ft}^{2}$ \\
\hline Basement/Slab Perimeter & $155 \mathrm{ft}^{2}$ \\
\hline Window & $245.7 \mathrm{ft}^{2}$ \\
\hline
\end{tabular}

prototype (or a wall with $12 \%$ to $13 \%$ glazing). We used a second method to estimate the window area in new homes. Mundy (1992) reported 595 million $\mathrm{ft}^{2}$ of glass was sold in 1990 in the new residential market. Using data on new housing construction from Characteristics of New Housing: 1991 (DOC 1992a), we estimated the average window-to-floor area percentage (across all types of residential housing units) to be roughly $13 \%$ to $14 \%$.

All of our nationwide sources for single-family window areas indicate a window-to-floor area ratio of $14 \%$ or less; however, this is an average value. The distribution of window areas in new housing varies around this average. For our analysis, we assumed a window area of $13 \%$ of the floor area $\left(245.7 \mathrm{ft}^{2}\right.$ or $14.2 \%$ of the gross wall area) for the prototype house. This assumption is on the high end of the average window area estimates.

\subsubsection{Defining Default Code Requirements}

Some state codes do not give complete requirements for all of the building components. For these codes, we assumed the following:

- Window requirements are sometimes given in terms of the number of window panes. We assumed $\mathrm{U}$-values of 1.18 and $0.72 \mathrm{Btu} / \mathrm{h} \cdot \mathrm{ft}^{2} \bullet^{\circ} \mathrm{F}$ to represent single-pane aluminum and doublepane aluminum windows, respectively. These values were the average $U$-values for single- and double-pane aluminum windows derived from a database of tested window U-values developed by the 1993 National Fenestration Rating Council (NFRC 1993). 
- Basement wall and slab wall insulation requirements are often given in terms of R-values, but with no specified depth requirements. We assumed basement wall insulation extended $8 \mathrm{ft}$ down and slab wall insulation extended $2 \mathrm{ft}$ down for the $U$-value comparison, based on the assumption that these depths are most common.

- For state codes with no door requirements, we used a door $U$-value of $0.6 \mathrm{Btu} / \mathrm{h} \bullet \mathrm{ft}^{2} \bullet^{\circ} \mathrm{F}$, which represents a fiberglass-core or mineral wool-core door with steel stiffeners and no thermal break (ASHRAE 1989a).

\subsubsection{Calculating Envelope Component U-Values and F-Values}

Most state codes describe envelope requirements in terms of R-values. To compare these requirements with the $1992 \mathrm{MEC}$, they must be translated into U-value requirements. Envelope U-values are based on the individual components of the entire building assembly. For example, a wall U-value depends not only on the thickness of insulation installed in the wall, but also on several other components of the wall such as the type of sheathing, type of siding, size of framing members, and spacing of the framing members. To estimate the U-values for building assemblies, several assumptions about the building construction must be made. The assumptions made for walls, ceilings, and floors over unheated spaces are outlined in Appendix B.

Calculating component U-values for walls, ceilings, and floors over unheated spaces is relatively straightforward. Because the methodology for calculating slab and basement wall U-values is more complicated, it will be discussed in more depth in this section.

\section{Foundation Walls}

The grossly simplified method of calculating basement and crawl space wall U-values by adding the wall components and surface air films in the $1992 \mathrm{MEC}$ (footnote 5 in Table 502.2.1) is inadequate for calculating heat loss. This method ignores heat loss through the foundation floor and does not consider the soil resistance.

Heat loss through below-grade foundations is complicated by the highly three-dimensional nature of the geometry of the foundations and surrounding soil. Heat leaves (or enters) the house in all directions through foundation walls and floors from the surrounding soil. To simplify this very complex heat transfer problem, all heat transfer is assumed to occur through the earth to the surface surrounding the building to the outside air (i.e., no heat transfer occurs with the earth itself) (ASHRAE 1989a, page 25.5). 
Insulation for foundation walls is normally only put around the building's perimeter. Therefore, the heat loss unit for below-grade foundations is in terms of linear foot of perimeter (F-value) instead of per square foot of surface area (U-value). A U-value is multiplied by a surface area and degree-days to obtain the total heat loss. An F-value is multiplied by a perimeter length and degree-days to obtain the total heat loss.

To calculate foundation heat losses, F-values for basement walls and slabs were taken from "WholeHouse Simulation of Foundation Heat Flows Using the DOE-2.1C Program" (Huang et al. 1988). These values are shown in Table 2.2. The F-values are given in Huang et al. (1988) for insulation both on the exterior and interior of the foundation wall. The F-values vary only slightly by insulation placement, so the average of the exterior and interior insulation placement was used. Huang et al. (1988) did not present F-values for insulation levels above R-10 for basement wall insulation $4 \mathrm{ft}$. deep or slab wall insulation $2 \mathrm{ft}$. deep. F-values were considered to be constant for insulation levels above R-10 for these configurations. Additionally, F-values were considered to be constant for all insulation levels above $\mathrm{R}-20$, regardless of insulation depth. This assumption was deemed reasonable because little is gained by the additional insulation (above R-20, most of the heat loss occurs under and around the insulation).

Table 2.2. Foundation Wall F-Values

\begin{tabular}{||l|c|c|c|c||}
\hline \multirow{2}{*}{$\begin{array}{c}\text { Insulation } \\
\text { R-Value }\end{array}$} & $\begin{array}{c}\text { Insulation } \\
\text { Depth }\end{array}$ & $\begin{array}{c}\text { Insulation } \\
\text { Depth }\end{array}$ & $\begin{array}{c}\text { Slabs } \\
\text { Insulation } \\
\text { Depth }\end{array}$ & $\begin{array}{c}\text { Basement Walls } \\
\text { Insulation } \\
\text { Depth }\end{array}$ \\
\hline \hline R-0 & 1.043 & 1.041 & 2.584 & 2.584 \\
\hline R-5 & 0.804 & 0.744 & 1.672 & 1.430 \\
\hline R-10 & 0.767 & 0.684 & 1.510 & 1.181 \\
\hline R-15 & 0.767 & 0.654 & 1.510 & 1.066 \\
\hline $\begin{array}{l}\text { R-20 and } \\
\text { Above }\end{array}$ & 0.767 & 0.636 & 1.510 & 0.996 \\
\hline
\end{tabular}


Foundation walls can be insulated to any depth. To calculate heat loss for any combination of insulation depth and R-value, quadratic curves were fit through the data in Table 2.3. The resulting quadratic Equation (2.1) gives the F-value as a function of insulation depth. The applicable coefficients for Equation (2.1) are given in Table 2.3 and are determined by the insulation $R$-value. Depths range from 0 to $8 \mathrm{ft}$ for basements and from 0 to $4 \mathrm{ft}$ for slabs. R-values range from R- 0 to R-20 for both basements and slabs.

Table 2.3. Coefficients for Foundation Wall F-Value Equation

\begin{tabular}{|c|c|c|c|c|c|c|c|}
\hline \multicolumn{4}{|c|}{ Slabs } & \multicolumn{4}{|c|}{ Basement Walls } \\
\hline R-Value & intercept & $\operatorname{coef} 1$ & $\operatorname{coef} 2$ & R-Value & intercept & coef 1 & $\operatorname{coef} 2$ \\
\hline R-0 & 2.584 & 0.0000 . & 0.0000 & R-0 & 1.042 & 0.0013 & -0.0004 \\
\hline R-1 & 2.584 & -0.1836 & 0.0139 & R-1 & 1.042 & -0.0967 & 0.0144 \\
\hline R-2 & 2.584 & -0.2451 & 0.0179 & $\mathrm{R}-2$ & 1.042 & -0.1293 & 0.0188 \\
\hline R-3 & 2.584 & -0.2768 & 0.0195 & $\mathrm{R}-3$ & 1.042 & -0.1459 & 0.0207 \\
\hline R-4 & 2.584 & -0.2970 & 0.0204 & $R-4$ & 1.042 & -0.1562 & 0.0217 \\
\hline R-5 & 2.584 & -0.3118 & 0.0209 & $\mathrm{R}-5$ & 1.042 & -0.1635 & 0.0223 \\
\hline R-6 & 2.584 & -0.3237 & 0.0214 & R-6 & 1.042 & -0.1692 & 0.0227 \\
\hline $\mathrm{R}-7$ & 2.584 & -0.3342 & 0.0218 & $\mathrm{R}-7$ & 1.042 & -0.1739 & 0.0230 \\
\hline R-8 & 2.584 & -0.3437 & 0.0222 & R-8 & 1.042 & -0.1781 & 0.0233 \\
\hline R-9 & 2.584 & -0.3528 & 0.0227 & R-9 & 1.042 & -0.1819 & 0.0236 \\
\hline R-10 & 2.584 & -0.3616 & 0.0233 & $\mathrm{R}-10$ & 1.042 & -0.1855 & 0.0240 \\
\hline R-11 & 2.584 & -0.3579 & 0.0223 & $R-11$ & 1.042 & -0.1836 & 0.0231 \\
\hline R-12 & 2.584 & -0.3546 & 0.0215 & $\mathrm{R}-12$ & 1.042 & -0.1819 & 0.0222 \\
\hline R-13 & 2.584 & -0.3518 & 0.0208 & $R-13$ & 1.042 & -0.1805 & 0.0215 \\
\hline R-14 & 2.584 & -0.3494 & 0.0202 & R-14 & 1.042 & -0.1792 & 0.0208 \\
\hline $\mathrm{R}-15$ & 2.584 & -0.3473 & 0.0197 & $R-15$ & 1.042 & -0.1780 & 0.0203 \\
\hline$R-16$ & 2.584 & -0.3453 & 0.0192 & $\mathrm{R}-16$ & 1.042 & -0.1770 & 0.0197 \\
\hline $\mathrm{R}-17$ & 2.584 & -0.3435 & 0.0188 & R-17 & 1.042 & -0.1760 & 0.0193 \\
\hline R-18 & 2.584 & -0.3419 & 0.0183 & $R-18$ & 1.042 & -0.1751 & 0.0188 \\
\hline R-19 & 2.584 & -0.3402 & 0.0179 & R-19 & 1.042 & -0.1743 & 0.0184 \\
\hline $\mathrm{R}-20$ & 2.584 & -0.3385 & 0.0175 & $\mathrm{R}-20$ & 1.042 & -0.1735 & 0.0180 \\
\hline
\end{tabular}




$$
\text { F-value }=\text { intercept }+ \text { coef } 1 x \text { depth }+ \text { coef } 2 \times \text { depth }^{2}
$$

where depth is the distance the insulation extends downward (or downward and outward) in feet.

Basement wall and slab wall F-values were calculated using Equation (2.1) for codes that contain basement wall and slab wall $R$-value requirements. When basement wall requirements were given in terms of a U-value, as in the $1992 \mathrm{MEC}$, these requirements were first translated into an insulation Rvalue. Then Equation (2.1) was used to calculate an F-value. U-values were translated into R-values by using the following equation:

$$
\mathrm{R}_{\mathrm{Ins}}=\frac{1}{\mathrm{U}_{\mathrm{w}}}-1.7
$$

where $R_{\text {Ins }}=$ the basement or slab wall insulation $R$-value

$U_{w}=$ the basement or slab wall $U$-value.

The constant 1.7 represents the R-value of the concrete wall or slab as well as the surface air films.

\subsubsection{Calculating Average Overall House U-Values $\left(\mathrm{U}_{\mathrm{o}}\right)$}

Calculating an average overall U-value involves summing the U-values of each building component multiplied by the surface area of the respective components. This sum is then divided by the sum of the surface areas of all the components. This calculation is given by Equation (2.3) for homes with insulated floors over unheated spaces.

$$
U_{0}=\frac{\left(U_{w} A_{w}\right)+\left(U_{g} A_{g}\right)+\left(U_{d} A_{d}\right)+\left(U_{c} A_{c}\right)+\left(U_{f} A_{f}\right)}{A_{w}+A_{g}+A_{d}+A_{c}+A_{f}}
$$

where $U_{w}=$ the thermal transmittance of the opaque wall area components

$A_{w}=$ the opaque wall area

$\mathrm{U}_{\mathrm{g}}=$ the thermal transmittance of the fenestration assembly area

$A_{g}=$ the fenestration assembly area

$\mathrm{U}_{\mathrm{d}}=$ the thermal transmittance of the door area

$A_{d}=$ the door area

$\mathrm{U}_{\mathrm{c}}=$ the thermal transmittance of the gross roof/ceiling area

$A_{c}=$ the area of the gross roof/ceiling

$\mathrm{U}_{\mathrm{f}}=$ the thermal transmittance of the gross floor area

$A_{f}=$ the floor area.

When calculating an average envelope U-value for homes with slabs, it is important to recognize that 
the F-value for the slab insulation is a measure of the heat loss for the entire floor. The F-value multiplied by the length of the perimeter is equivalent to a calculated UA value where the area is the total surface area of the floor. Therefore, Equation (2.4) is used to calculate an average envelope U-value when the slab wall is insulated.

$$
U_{0}=\frac{\left(U_{w} A_{w}\right)+\left(U_{g} A_{g}\right)+\left(U_{d} A_{d}\right)+\left(U_{c} A_{c}\right)+\left(F_{f} P_{f}\right)}{A_{w}+A_{g}+A_{d}+A_{c}+A_{f}}
$$

where $F_{f}=$ the heat loss coefficient per foot of slab perimeter

$P_{\mathrm{f}}=$ the perimeter of the slab foundation.

When calculating an average envelope U-value for homes with basements, it is important to recognize that the $\mathrm{F}$-value for the basement insulation is a measure of the heat loss for the entire basement, including the basement walls and basement floor. The F-value multiplied by the length of the perimeter is equivalent to a calculated UA value where the area is the total surface area of the basement. Therefore, Equation (2.5) is used to calculate an average envelope U-value when the basement wall is insulated.

$$
U_{0}=\frac{\left(U_{w} A_{w}\right)+\left(U_{g} A_{g}\right)+\left(U_{d} A_{d}\right)+\left(U_{c} A_{c}\right)+\left(F_{b} P_{f}\right)}{A_{w}+A_{g}+A_{d}+A_{c}+A_{b f}+A_{b w}}
$$

where $F_{b}=$ the heat loss coefficient per foot of basement perimeter

$P_{f}=$ the perimeter of the basement foundation

$A_{b f}=$ the area of the basement floor

$A_{b w}=$ the gross area of the basement walls.

\subsubsection{Calculating State Average U-Values}

Because the 1992 MEC requirements vary by heating degree-days, we calculated a state's average MEC envelope requirements using several cities in that state. The cities included in the analyses are delineated in Conner and Lucas (1993). The cities came from a group of 881 U.S. cities and are listed in Appendix $A$ for the states requiring a $U_{0}$ comparison. Heating degree-days for the cities. were taken from work in progress from ASHRAE Standard 90.2 (ASHRAE 1994). The U-values for the cities were averaged together, weighted by data obtained from the Bureau of the Census (DOC 1992b) on 1992 housing starts using the following equation: 


$$
\mathrm{U}_{\text {state avg }}=\frac{\mathrm{U}_{\text {city } 1} \mathrm{HS}_{\text {city 1 }}+\mathrm{U}_{\text {city 2 }} \mathrm{HS}_{\text {city 2 }}+\ldots+\mathrm{U}_{\text {city N }} \mathrm{HS}_{\text {city N }}}{\mathrm{HS}_{\text {city 1 }}+\mathrm{HS}_{\text {city 2 }}+\ldots+\mathrm{HS}_{\text {city N }}}
$$

where $U_{\text {state avg }}=$ the state average overall building $U$-value

$\mathrm{U}_{\text {city }}=$ the overall building $\mathrm{U}$-value for the indicated city

$\mathrm{HS}_{\text {city }}=$ the housing starts for the indicated city.

Any state code expressing requirements as a function of heating degree-days or by geographic region was similarly summarized into an average state requirement. This methodology may conclude that, overall, a state's code is equal in efficiency to the $1992 \mathrm{MEC}$, but does not guarantee that every complying house also complies with the MEC.

\subsubsection{Calculating Foundation Average $U_{o}$}

Some state codes have foundation insulation requirements that exceed those of the 1992 MEC for some foundation types, but do not meet the MEC for other types. To address this possibility, we calculated an average envelope $U$-value requirement weighted by foundation type prevalence. This requirement prevents, for example, noncomplying basement criteria from disqualifying a code in a southern state where basements are rare.

The information for weighting the U-values based on foundation type and the placement of insulation was obtained from two different sources. The first source (NAHB 1991) contains information on the predominance of foundation types for new residential construction on a state-by-state basis. This source does not delineate the type of insulation used in basements--basement wall insulation versus floor insulation over the basement. A second source was used to approximate the type of insulation used for homes with basements; i.e., basement wall insulation or floor insulation over the basement. This source (Christian 1988) gives information about the placement of foundation insulation in new single-family homes, as well as the foundation type.

The foundation percentages for the states where a U-value comparison was performed are given in Appendix A in the tables entitled "Average Overall Envelope U-Value by Foundation Type." A code's state average overall envelope U-values for each foundation type were thus averaged together and weighted by these foundation percentages, resulting in a single state-wide average overall envelope U-value.

\subsubsection{Comparing Average $U_{o}$}

We consider any state code with a $U_{0}$ below that of the 1992 MEC to meet or exceed the 1992 MEC. We consider any state code with a $U_{0}$ above that of the MEC to fail to meet or exceed the $1992 \mathrm{MEC}$. A $\mathrm{U}_{\mathrm{o}}$ within $\pm 5 \%$ of the $1992 \mathrm{MEC}$ is considered to marginally pass or marginally fail because of uncertainties in the energy consequences of U-value tradeoffs between components, uncertainties in our weighting factors for housing starts and foundation types, and the variation in component areas among 
buildings. For example, a state code that passes by less than $5 \%$ may be shown to fail if a different building prototype were examined or if the nuances of roof heat losses by radiation to the sky were thoroughly considered. Our methodology may unambiguously pass a code that is within the $\pm 5 \%$ region if its requirements lend themselves to a component-by-component comparison with the MEC, whereas another code with the same $U_{0}$ may be considered to only marginally pass because its component requirements differ.

Because of the uncertainties inherent in the $U_{0}$ comparison, we applied two additional steps. Codes that either marginally passed or marginally failed were reviewed for possible unique characteristics that might clarify the comparison. Several such codes are discussed in Section 2.5.10. Any code that either passed or marginally failed was further reviewed for duct insulation requirements.

\subsubsection{Examining Duct Insulation}

The duct insulation requirements for all state codes resulting in a $U_{0}$ within $\pm 5 \%$ of the $1992 \mathrm{MEC}$ $\mathrm{U}_{0}$, as well as those that unambiguously passed, were reviewed. State codes that adopt the $1992 \mathrm{MEC}$ with amendments were examined for duct insulation requirements to verify the amendments do not reduce the duct insulation requirements. State codes that unambiguously failed to meet the MEC requirements were not reviewed because the $1992 \mathrm{MEC}$ duct insulation requirements are fairly stringent. Of all the state codes reviewed, none had duct insulation requirements significantly higher than the MEC requirements. Thus, a code not meeting the $\mathrm{MEC}$ requirements would be unlikely to have duct insulation more stringent than the MEC or stringent enough to change the code's classification from not meeting to meeting the $\mathrm{MEC}$ requirements.

The $1992 \mathrm{MEC}$ requires the duct insulation R-value to be equal to the difference in the design temperature differential between the air in the duct and the outside duct surface in degrees Fahrenheit divided by $15(R=\Delta t / 15)$. For ducts located in attics, the temperature of the duct surface was set equal to the winter design temperature plus $10^{\circ} \mathrm{F}$ as specified in the MEC. The temperature of the air in the duct was assumed to be $130^{\circ} \mathrm{F}$.

The design temperature is dependent on the home's geographic location. Most of the design temperatures used in our examination were from the 1993 ASHRAE Handbook Fundamentals (ASHRAE 1993). When a design temperature was not available for a city, the design temperature was approximated based on the heating degree-days for the city. The duct requirements for the individual cities within the state were averaged, weighted by the housing starts, to compute a state average duct insulation requirement for the MEC. All of the state code duct requirements were either in the same format as the MEC requirement (i.e., $R=\Delta t / 15$ ) or a single insulation value was given for the whole state. When the state code requirement was the same as the MEC, no further analysis was necessary. When the state code requirement was different than the MEC, the duct losses resulting from insulating to the MEC levels were compared with duct losses resulting from insulating in accordance with the state code. 
To estimate duct losses, we assumed an overall duct efficiency of $75 \%$ (i.e., $25 \%$ of the energy delivered to the duct system will be lost) for ducts with R-4 insulation based on Conner and Lucas (1993). One-third of the duct losses (approximately $8 \%$ of the delivered energy) were estimated to be attributable to conduction losses. To evaluate state codes' duct insulation requirements against those of the 1992 MEC, we scaled the conduction duct losses of the R-4 duct up or down in proportion to the actual R-value requirements. For example, a duct with R-8 insulation was assumed to have half the conduction losses of the $\mathrm{R}-4$ duct.

Because conduction losses from ducts located within a building's thermal envelope do not increase the energy consumption of the home, we adjusted our duct loss estimates downward to account for the fraction of ducts located in conditioned spaces. We estimated that $80 \%$ of ducts are located in unconditioned spaces. The conduction loss estimates were multiplied by 0.80 to reflect this estimate. The conduction duct loss estimates were further adjusted to reflect the fraction of homes with ducts, using regional heating system information given in Characteristics of New Housing: 1991 (DOC 1992a).

Equation (2.7) was used to compute the difference in duct losses resulting from the different duct insulation requirements on average for the state.

$$
\Delta \mathrm{DL}=0.08 \bullet\left(4 / \mathrm{R}_{\mathrm{MEC}}-4 / \mathrm{R}_{\mathrm{Statc}}\right) \cdot 0.80 \bullet \% \text { homes with ducts }
$$

$$
\begin{aligned}
& \text { where } \quad \Delta D L=\text { the difference in the percentage of lost HVAC energy from duct losses as a } \\
& \text { result of insulating to the state code level instead of to the MEC level as an aver- } \\
& \text { age value for the state } \\
& R_{M E C}=\text { the state average } M E C \text { insulation requirement } \\
& \mathbf{R}_{\text {State }}=\text { the insulation } \mathbf{R} \text {-value requirement of the state code }
\end{aligned}
$$

All analyzed state codes (except for one) have a small difference in conduction duct losses resulting from the difference in the duct insulation requirements-less than 3\% of the total HVAC energy delivered to the duct system. The duct insulation requirements for these state codes were examined individually and evaluated as not being significant enough to change the state codes' categorizations from meeting to not meeting the MEC requirements. The Iowa State Building Code (1993) was the one state code with a greater than 3\% difference because of duct losses (Iowa State Building Code Advisory Council 1993). The state code requirements result in an approximate $12 \%$ loss of energy delivered to the duct system, while the 1992 MEC requirements result in a 3\% loss. Consequently, Iowa was moved from meeting to not meeting the $\mathrm{MEC}$ requirements. 


\subsubsection{Example of U-Value Calculation}

Comparing average overall $\mathrm{U}$-values for state codes and the MEC requires several calculations. To clarify the calculation process, a detailed example is presented below. Appendix A contains a briefer synopsis for individual states. The state code used for this example is the Washington nonelectric code.

The Washington State Energy Code (1994) is the mandatory state energy code for new residential construction. The Washington code divides the state into two regions and gives separate requirements for electric and nonelectric homes. Compliance may be achieved through a systems analysis approach or by a component performance approach. These methods are assumed to result in approximately equivalent energy use. An overall U-value comparison was performed for the state using the component performance approach as a basis. The comparison is based on several cities within the state. The cities, the necessary design information, and housing starts for each city are shown in Table 2.4. The $U_{0}$ comparison involves six steps.

\section{Step 1. Identify Code Requirements for State Code and 1992 MEC}

The component performance approach gives several prescriptive $\mathrm{R}$-value paths for compliance, which are assumed to result in approximately equivalent energy use. The Washington code specifies a "reference" case that is used for the comparison. Basement wall requirements differ depending on the placement of the insulation-interior versus exterior. For the analysis, the basement wall insulation was in the interior of the walls because this location was assumed to be most common. The Washington code's $\mathrm{R}$-value requirements for the two regions are shown in Table 2.5. The MEC envelope requirements for each city are taken from Figures 1,2, 3, 6, and 8 in the 1992 MEC. The MEC envelope component requirements are given in Table 2.6.

\section{Step 2. Transform Requirements Into U-Values and F-Values}

The Washington code's R-value requirements may be translated to U-value requirements as described in Section 2.5.3 and Appendix B. The equivalent nonelectric $U$-values requirements for ceilings, walls, and floors over unheated spaces, and F-values, for slab and basement walls, are given in Table 2.7 for the Washington nonelectric code. Basement wall and slab perimeter F-values for the MEC are also shown in Table 2.6. The F-values were computed according to the methodology described in Section 2.5 .3 and Equation (2.1).

State average and region average building component $U$-values are also shown in Tables 2.6 and 2.7. These average values are calculated using Equation (2.6) where the U-values are component U-values instead of overall building $U$-values. The state average building component $U$-values are not necessary for the $U_{0}$ comparison methodology, but they may be useful to states when evaluating how to change the state codes to meet the 1992 MEC. When the average building component U-values for the state codes 
Table 2.4. Design Information and Housing Starts for Washington Cities

\begin{tabular}{|c|c|c|c|c|}
\hline City & Region & HDD & Housing Starts & Design Temp \\
\hline Aberdeen & 1 & 5321 & 0 & 28 \\
\hline Bellingham & 1 & 5640 & 1615 & 15 \\
\hline Bremerton & 1 & 5194 & 2398 & 25 \\
\hline Centralia & 1 & 5083 & 270 & 14 \\
\hline Everett & 1 & 5354 & 4396 & 25 \\
\hline Kennewick & 1 & 4854 & 774 & 11 \\
\hline Kent & 1 & 5075 & 389 & 17 \\
\hline Longview & 1 & 5063 & 391 & 24 \\
\hline Moses Lake & 2 & 6296 & 153 & 7 \\
\hline Olympia & 1 & 5710 & 2336 & 22 \\
\hline $\begin{array}{l}\text { Port } \\
\text { Angeles }\end{array}$ & 1 & 5714 & 759 & 27 \\
\hline Pullman & 2 & 6757 & 0 & 3 \\
\hline Puyallup & 1 & 5145 & 297 & 18 \\
\hline Richland & 1 & 4710 & 215 & 10 \\
\hline Seattle & 1 & 5122 & 10165 & 26 \\
\hline Spokane & 2 & 6885 & 3486 & 2 \\
\hline Tacoma & 1 & 4795 & 5950 & 24 \\
\hline Vancouver, & 1 & 5031 & 4584 & 13 \\
\hline Walla Walla & 1 & 5057 & 251 & 7 \\
\hline Wenatchee & 2 & 5698 & 482 & 11 \\
\hline Yakima & 1 & 6035 & 996 & 5 \\
\hline Region 1 & -- & - & $35,786(90 \%)$ & \\
\hline Region 2 & -- & -- & $4,121(10 \%)$ & \\
\hline
\end{tabular}


Table 2.5. Washington Nonelectric Code R-Value Requirements

\begin{tabular}{||l|c|c||}
\hline & Region 1 & Region 2 \\
\hline Ceiling & $\mathrm{R}-30$ & $\mathrm{R}-38$ \\
\hline Above-Grade Wall & $\mathrm{R}-19$ & $\mathrm{R}-19$ \\
\hline Floor & $\mathrm{R}-19$ & $\mathrm{R}-30$ \\
\hline Basement Wall & $\mathrm{R}-19$ & $\mathrm{R}-19$ \\
\hline Slab-On-Grade & $\mathrm{R}-10$ & $\mathrm{R}-10$ \\
\hline Window & $\mathrm{U}=0.65$ & $\mathrm{U}=0.60$ \\
\hline Door & $\mathrm{U}=0.40$ & $\mathrm{U}=0.40$ \\
\hline Duct & $\mathrm{R}-8$ & $\mathrm{R}-8$ \\
\hline
\end{tabular}

Table 2.6. MEC Envelope Component Requirements for Washington

\begin{tabular}{||l|c|c|c|c|c|c|c|c|c||}
\hline \multicolumn{1}{|c|}{ City } & $\begin{array}{c}\text { Wall } \\
\text { U-Value }\end{array}$ & $\begin{array}{c}\text { Ceiling } \\
\text { U-Value }\end{array}$ & $\begin{array}{c}\text { Floor } \\
\text { U-Value }\end{array}$ & $\begin{array}{c}\text { Slab } \\
\text { R-Value }\end{array}$ & $\begin{array}{c}\text { Slab } \\
\text { Depth }\end{array}$ & $\begin{array}{c}\text { Basement } \\
\text { U-Value }\end{array}$ & $\begin{array}{c}\text { Slab } \\
\text { F-Value }\end{array}$ & $\begin{array}{c}\text { Basement } \\
\text { F-Value }\end{array}$ & $\begin{array}{c}\text { Duct } \\
\text { R-Value }\end{array}$ \\
\hline \hline Aberdeen & 0.136 & 0.029 & 0.05 & 4.5 & 2 & 0.098 & 0.810 & 1.234 & 7 \\
\hline Bellingham & 0.131 & 0.028 & 0.05 & 4.8 & 2 & 0.097 & 0.807 & 1.231 & 8 \\
\hline Bremerton & 0.138 & 0.030 & 0.05 & 4.4 & 2 & 0.098 & 0.811 & 1.236 & 7 \\
\hline Centralia & 0.140 & 0.030 & 0.05 & 4.4 & 2 & 0.098 & 0.812 & 1.237 & 8 \\
\hline Everett & 0.136 & 0.029 & 0.05 & 4.6 & 2 & 0.098 & 0.809 & 1.234 & 7 \\
\hline Kennewick & 0.143 & 0.032 & 0.05 & 4.2 & 2 & 0.099 & 0.814 & 1.239 & 8 \\
\hline Kent & 0.140 & 0.030 & 0.05 & 4.4 & 2 & 0.099 & 0.812 & 1.237 & 7 \\
\hline Longview & 0.140 & 0.031 & 0.05 & 4.4 & 2 & 0.099 & 0.812 & 1.237 & 7 \\
\hline Moses Lake & 0.121 & 0.026 & 0.05 & 5.2 & 4 & 0.095 & 0.742 & 1.224 & 8 \\
\hline Olympia & 0.130 & 0.027 & 0.05 & 4.8 & 2 & 0.097 & 0.807 & 1.230 & 7 \\
\hline Port Angeles & 0.130 & 0.027 & 0.05 & 4.8 & 2 & 0.097 & 0.807 & 1.230 & 7 \\
\hline Pullman & 0.114 & 0.026 & 0.05 & 5.5 & 4 & 0.094 & 0.737 & 1.219 & 8 \\
\hline Puyallup & 0.139 & 0.030 & 0.05 & 4.4 & 2 & 0.098 & 0.811 & 1.236 & 7 \\
\hline
\end{tabular}


Table 2.6. (contd)

\begin{tabular}{||l|c|c|c|c|c|c|c|c|c||}
\hline Richland & 0.146 & 0.032 & 0.05 & 4.1 & 2 & 0.100 & 0.815 & 1.241 & 8 \\
\hline Seattle & 0.139 & 0.030 & 0.05 & 4.4 & 2 & 0.098 & 0.811 & 1.236 & 7 \\
\hline Spokane & 0.112 & 0.026 & 0.05 & 5.6 & 4 & 0.094 & 0.735 & 1.217 & 8 \\
\hline Tacoma & 0.144 & 0.032 & 0.05 & 4.2 & 2 & 0.099 & 0.814 & 1.240 & 7 \\
\hline Vancouver & 0.141 & 0.031 & 0.05 & 4.4 & 2 & 0.099 & 0.812 & 1.238 & 8 \\
\hline Walla Walla & 0.140 & 0.031 & 0.05 & 4.4 & 2 & 0.099 & 0.812 & 1.237 & 8 \\
\hline Wenatchee & 0.130 & 0.027 & 0.05 & 4.8 & 2 & 0.097 & 0.807 & 1.230 & 8 \\
\hline Yakima & 0.125 & 0.026 & 0.05 & 5.0 & 4 & 0.096 & 0.744 & 1.227 & 8 \\
\hline Region 1 & 0.138 & 0.030 & 0.05 & - & - & 0.098 & 0.766 & 1.236 & 7.24 \\
\hline Region 2 & 0.114 & 0.026 & 0.05 & - & - & 0.094 & 0.780 & 1.219 & 8.00 \\
\hline $\begin{array}{l}\text { State } \\
\text { Average }\end{array}$ & 0.136 & 0.030 & 0.05 & - & - & 0.097 & 0.769 & 1.234 & 7.32 \\
\hline
\end{tabular}

Table 2.7. Washington Nonelectric Code U-Value and F-Value Requirements

\begin{tabular}{||l|c|c|c||}
\hline & Region 1 & Region 2 & State Average \\
\hline Ceiling U-Value & 0.035 & 0.030 & 0.035 \\
\hline Wall U-Value & 0.150 & 0.143 & 0.149 \\
\hline Floor U-Value & 0.047 & 0.033 & 0.046 \\
\hline Basement F-Value & 1.008 & 1.008 & 1.008 \\
\hline Slab F-Value & 0.767 & 0.767 & 0.767 \\
\hline Duct R-Value & 8.000 & 8.000 & 8.000 \\
\hline
\end{tabular}


are compared to the average MEC envelope component U-values, it is easy to identify if the requirements for one- or two-building components cause a state code to not meet the MEC requirements or if the requirements in a particular region are not stringent enough.

\section{Step 3. Calculate $U_{0}$ for Each City and Foundation Type}

Overall envelope $U$-values were then calculated for each city and each of the three foundation types using Equations (2.3), (2.4), and (2.5). Table 2.8 shows the $U_{0}$ for each city and foundation type for both the MEC and the Washington code.

\section{Step 4. Calculate Average $U_{0}$ for Each Foundation Type Across the State}

The $\mathrm{U}_{0} \mathrm{~s}$ are averaged across the state, weighted by housing starts using Equation (2.6). State average $\mathrm{U}_{0} \mathrm{~s}$ for each foundation type are shown in Table 2.9 for the MEC and the Washington code requirements.

\section{Step 5. Calculate State Average $U_{0}$}

To compute a single state overall $U$-value, the average values for the different foundation types were averaged together, weighted by the prevalence of that foundation type. The percentage of homes for the given foundation types are shown in parentheses in Table $2.9(4 \%, 85 \%$, and $11 \%)$. The Washington code's single overall U-values are shown in Table 2.10.

The average overall Washington code U-value is above the average overall 1992 MEC U-value. The percent difference in the $U$-values $(6 \%)$ is greater than $5 \%$. Therefore, the code is classified as not meeting the 1992 MEC requirements.

\section{Step 6. Review Duct Requirements}

Because the Washington code unambiguously does not meet the $1992 \mathrm{MEC}$, the methodology does not require any further analysis. However, to clarify the duct insulation analysis performed on states that meet or marginally fail to meet the $1992 \mathrm{MEC}$ requirements, an example of the analysis is done below.

The Washington code requires R-8 duct insulation for ducts in attics or crawl spaces. The 1992 MEC requirement for ducts varies from city to city, depending on the design conditions. The MEC duct requirements are shown in Table 2.6. These requirements are based on a duct design air temperature of $130^{\circ} \mathrm{F}$ and the design temperature given in Table 2.4. The duct wall temperature is calculated to be $10^{\circ} \mathrm{F}$ above the design temperature, according to the MEC, based on the assumption that the ducts are placed in the attic. The duct requirements were rounded off to reflect commercially available insulation levels. The MEC duct insulation requirements were then averaged, weighted by housing starts, to give a state average duct insulation requirement. In the West, $85 \%$ of the homes have ducts. Equation (2.7) was used 
Table 2.8. Washington Nonelectric Code and the $1992 \mathrm{MEC} \mathrm{U}_{0} \mathrm{~s}$ by Foundation Type

\begin{tabular}{||l|c|c|c|c|c|c||}
\hline & $\begin{array}{c}\text { State Slab } \\
\mathrm{U}_{\mathrm{o}}\end{array}$ & $\begin{array}{c}\text { MEC } \\
\text { Slab } \mathrm{U}_{\circ}\end{array}$ & $\begin{array}{c}\text { State Floor } \\
\mathrm{U}_{\circ}\end{array}$ & $\begin{array}{c}\text { MEC Floor } \\
\mathrm{U}_{\circ}\end{array}$ & $\begin{array}{c}\text { State } \\
\text { Basement } \mathrm{U}_{\circ}\end{array}$ & $\begin{array}{c}\text { MEC } \\
\text { Basement } \mathrm{U}_{\text {o }}\end{array}$ \\
\hline \hline Aberdeen & 0.0939 & 0.0867 & 0.0826 & 0.0763 & 0.0803 & 0.0807 \\
\hline Bellingham & 0.0939 & 0.0843 & 0.0826 & 0.739 & 0.0803 & 0.0788 \\
\hline Bremerton & 0.0939 & 0.0876 & 0.0826 & 0.0772 & 0.0803 & 0.0815 \\
\hline Centralia & 0.0939 & 0.0884 & 0.0826 & 0.0780 & 0.0803 & 0.0822 \\
\hline Everett & 0.0939 & 0.0864 & 0.0826 & 0.0760 & 0.0803 & 0.0805 \\
\hline Kennewick & 0.0939 & 0.0901 & 0.0826 & 0.0797 & 0.0803 & 0.0836 \\
\hline Kent & 0.0939 & 0.0885 & 0.0826 & 0.0781 & 0.0803 & 0.0822 \\
\hline Longview & 0.0939 & 0.0886 & 0.0826 & 0.0782 & 0.0803 & 0.0823 \\
\hline Moses Lake & 0.0895 & 0.0813 & 0.0736 & 0.0695 & 0.0769 & 0.0751 \\
\hline Olympia & 0.0939 & 0.0838 & 0.0826 & 0.0734 & 0.0803 & 0.0784 \\
\hline Port Angeles & 0.0939 & 0.0838 & 0.0826 & 0.0734 & 0.0803 & 0.0783 \\
\hline Pullman & 0.0895 & 0.0785 & 0.0736 & 0.0068 & 0.0769 & 0.0728 \\
\hline Puyallup & 0.0939 & 0.0880 & 0.0826 & 0.0776 & 0.0803 & 0.0818 \\
\hline Richland & 0.0939 & 0.0912 & 0.0826 & 0.0808 & 0.0803 & 0.0844 \\
\hline Seattle & 0.0939 & 0.0881 & 0.0826 & 0.0774 & 0.0803 & 0.0819 \\
\hline Spokane & 0.0895 & 0.0778 & 0.0736 & 0.0660 & 0.0769 & 0.0722 \\
\hline Tacoma & 0.0939 & 0.0906 & 0.0826 & 0.0802 & 0.0803 & 0.0839 \\
\hline Vancouver & 0.0939 & 0.0888 & 0.0826 & 0.0784 & 0.0803 & 0.0825 \\
\hline Walla Walla & 0.0939 & 0.0886 & 0.0826 & 0.0782 & 0.0803 & 0.0823 \\
\hline Wenatchee & 0.0895 & 0.0839 & 0.0736 & 0.0735 & 0.0769 & 0.0784 \\
\hline Yakima & 0.0939 & 0.0828 & 0.0826 & 0.0710 & 0.0803 & 0.0764 \\
\hline \hline
\end{tabular}


Table 2.9. Average Envelope $U_{0} s$ by Foundation Type for Washington Nonelectric Code and the $1992 \mathrm{MEC}$

\begin{tabular}{||l|c|c|c||}
\hline \multicolumn{1}{|c|}{ Zone } & $\begin{array}{c}\text { Slab-On-Grade } \\
(4 \%)\end{array}$ & $\begin{array}{c}\text { Floor Over Unheated } \\
\text { Space (85\%) }\end{array}$ & $\begin{array}{c}\text { Basement Wall } \\
(11 \%)\end{array}$ \\
\hline State Code Zone 1 & 0.094 & 0.083 & 0.80 \\
\hline State Code Zone 2 & 0.090 & 0.074 & 0.077 \\
\hline State Code Average & 0.093 & 0.082 & 0.080 \\
\hline MEC Zone 1 & 0.088 & 0.077 & 0.082 \\
\hline MEC Zone 2 & 0.079 & 0.067 & 0.073 \\
\hline MEC Average & 0.087 & 0.076 & 0.081 \\
\hline
\end{tabular}

Table 2.10. Average Overall Envelope U-Values for Washington Nonelectric Code and the $1992 \mathrm{MEC}$

\begin{tabular}{||l|c|c||}
\hline \multicolumn{1}{|c|}{ Zone } & MEC & State Code \\
\hline Zone 1 & 0.078 & 0.083 \\
\hline Zone 2 & 0.068 & 0.075 \\
\hline Average & 0.077 & 0.082 (6\% above MEC avg.) \\
\hline
\end{tabular}

to calculate the difference in duct losses resulting from the different duct insulation requirements. The difference is $-0.1 \%$ of the energy delivered to the duct system; i.e., the duct losses resulting from compliance with the state code are an estimated $3.4 \%$ versus $3.5 \%$ for compliance with the MEC.

The Washington code's duct insulation requirements do not significantly reduce duct losses. Therefore, the Washington nonelectric code still does not meet the 1992 MEC requirements. 


\subsubsection{State Codes with Unusual Provisions}

A few state codes have unusual provisions that make them difficult to categorize using our methodology. The Hawaii Model Energy Code (1993) is one example. The complete lack of heating loads in Hawaii makes its state code difficult to assess in the context of our U-value -based methodology. An energy comparison was performed using the Automated Residential Energy Standard (ARES) program $^{(a)}$ (Lortz and Taylor 1989). A prototype home built to the state code was compared with one built to the 1992 MEC (CABO 1992a). The home built to the state code unambiguously used less energy than the home built to the MEC. Therefore, the Hawaii code meets 1992 MEC requirements for one- and two-family dwellings. However, the code is not currently mandatory.

We have categorized South Carolina's code, the South Carolina 1993 Building Energy Efficiency Standard Act (1993), as unambiguously failing to meet or exceed the 1992 MEC. This state code explicitly references the current edition of the SBCCI Standard Building Code (which does not meet or exceed the 1992 MEC because it allows compliance with ANSI/ASHRAE/IES Standard 90A-1980 [ASHRAE 1980]), but modifies the code in such a way that it marginally meets the $1992 \mathrm{MEC}$ requirements. However, the code contains a clause to "facilitate the affordability of purchases of housing" that allows significantly lower insulation levels, provided the builder discloses those levels to the buyer and to the South Carolina Residential Builders Commission.

Vermont's state code, under Act 250 (10 V.S.A. 6001 et seq.), is unusual because a legislative act empowers a separate "commission" in each of nine geographic regions to ensure residential construction in that region uses "energy conservation principles" and achieves "efficient use of recovered energy." The commissions ostensibly evaluate every house individually. Although a set of prescriptive guidelines exists to assist builders in submitting proposals to the commissions, and those guidelines result in a $U_{o}$ nearly identical to that of the $1992 \mathrm{MEC}$, each commission is free to adopt its own unique interpretation of the state code's requirements and to implement its own procedures for verifying compliance of individual houses. We were unable to evaluate the stringency of Vermont's code. We do note, however, that not all new residential construction is subject to the commissions' oversight.

(a) The ARES energy simulation is a parameterization of a large database of DOE-2 simulations, allowing the simulation to estimate the energy use given a set of thermal envelope requirements. 


\subsection{References}

94 FR 17259. July 1994. "Building Energy Standards Program; Updating State Building Codes Regarding Energy Efficiency." Federal Register.

Act 250. (10 V.S.A. 6001 et seq.), Criterion 9(F), "Energy Conservation." State of Vermont, Department of Public Service, Montpelier, Vermont.

American Architectural Manufacturers Association (AAMA). 1992. Study of the Residential Window and Skylight Markets. Palatine, Illinois.

American Society of Heating, Refrigerating and Air-Conditioning Engineers, Inc. (ASHRAE). 1980. ANSI/ASHRAE/IES Standard 90A-1980, "Energy Conservation in New Building Design." New York.

American Society of Heating, Refrigerating and Air-Conditioning Engineers, Inc. (ASHRAE). 1989a. 1989 ASHRAE Handbook Fundamentals. Atlanta, Georgia.

American Society of Heating, Refrigerating and Air-Conditioning Engineers, Inc. (ASHRAE). 1989b. ASHRAE/IES Standard 90.1-1989, "Energy Efficient Design of New Buildings Except Low-Rise Residential Buildings." Atlanta, Georgia.

American Society of Heating, Refrigerating and Air-Conditioning Engineers, Inc. (ASHRAE). 1993. 1993 ASHRAE Handbook Fundamentals. Atlanta, Georgia.

American Society of Heating, Refrigerating and Air-Conditioning Engineers, Inc. (ASHRAE). 1994. ASHRAE Standard 90.2-1994, "Energy Efficient Design of New Low-Rise Residential Buildings." New York.

Building Officials and Code Administrators International, Inc. (BOCA). Updated every three years. BOCA National Building Code. Country Club Hills, Illinois.

Conner, C. C., and R. G. Lucas. 1993. Technical Support Document for Proposed Revision of the Model Energy Code Thermal Envelope Requirements. PNL-8546, Pacific Northwest Laboratory, Richland, Washington.

Council of American Building Officials (CABO). 1989. Model Energy Code; 1989 Edition. Falls Church, Virginia.

Council of American Building Officials (CABO). 1992a. Model Energy Code; 1992 Edition. Falls Church, Virginia. 
Council of American Building Officials (CABO). 1992b. Model Energy Code; Thermal Envelope Compliance Guide for One- and Two-Family Dwellings; 1992 Edition. Falls Church, Virginia.

Council of American Building Officials (CABO). 1993. Model Energy Code; 1993 Edition. Falls Church, Virginia.

Christian, J. E. 1988. "Foundation Futures: Energy Saving Opportunities Offered by ASHRAE Standard 90.2P." ASHRAE Transactions 94(2): 979-1002.

Energy Conservation and Production Act of 1976. 42 USC 6831 et seq., as amended.

Energy Policy Act of 1992 (EPAct). Public Law 102-486, 106 Stat 2776.

Hawaii Model Energy Code. 1993. Energy Division, Department of Business, Economic Development and Tourism, "Energy Efficiency Standard for Buildings." Honolulu, Hawaii.

Huang, Y. L., L. S. Shen, J. C. Bull, and L. F. Goldberg. 1988. "Whole-House Simulation of Foundation Heat Flows Using the DOE-2.1C Program." In ASHRAE Annual Meeting (Technical Papers), vol. 94, part 2, pp. 936-958, CONF-880627. June 25-29, 1988, Ottawa, Canada. American Society of Heating, Refrigerating and Air-Conditioning Engineers, Inc., Atlanta, Georgia.

International Conference of Building Officials (ICBO). 1991. Uniform Building Code. Whittier, California.

International Conference of Building Officials (ICBO). 1994. Uniform Building Code. Whittier, California.

International Conference of Building Officials (ICBO). Updated annually. Uniform Building Code. Whittier, Califormia.

Iowa State Building Code. 1993. ISBC 800.1, Iowa State Building Code Advisory Council, Des Moines, Iowa.

Johnson, A. W. 1987. "A Preliminary Analysis of Proposal 87-20 (MIMA) to the Model Energy Code." Johnson and Associates, Gaithersburg, Maryland.

Lortz, V. B., and Z. T. Taylor. 1989. Recommendations for Energy Conservation Standards for New Residential Buildings. Volume 2: Automated Residential Energy Standard - User's Guide - Version 1.1. PNL-6878 Vol. 2, Pacific Northwest Laboratory, Richland, Washington.

Mundy, E. 1992. Flat Glass Products and Markets. Business Research Report B269, The Freedonia Group, Inc., Cleveland, Ohio. 
NAHB Research Foundation, Inc. (NAHB). 1991. 1991 NAHB Research Foundation Special Report. Lexington, Massachusetts.

National Appliance Energy Conservation Act (NAECA) of 1987. Public Law 100-12, as amended, 42 USC 6201 et seq.

National Fenestration Rating Council (NFRC). 1993. Certified Products Directory. 2nd ed. Silver Spring, Maryland.

South Carolina 1993 Building Energy Efficiency Standard Act. 1993. State of South Carolina, Governor's Office of Energy Programs, Columbia, South Carolina.

Southern Building Code Congress International (SBCCI). Updated every three years. Standard Building Code. Birmingham, Alabama.

U.S. Department of Commerce (DOC). 1992a. Characteristics of New Housing: 1991. C25-91-A, Washington, D.C.

U.S. Department of Commerce (DOC), Bureau of the Census. 1992b. Housing Units Authorized by Building Permits: December 1992. Current Construction Reports. C40/92-12, Washington, D.C.

Washington State Energy Code. 1994. Chapter 51-11 WAC, Washington Association of Building Officials, Olympia, Wașhington. 


\section{Appendix A}

\section{State Residential Energy Codes}




\begin{abstract}
Alabama
Alabama has not adopted a state residential energy code. Therefore, Alabama does not meet the 1992 MEC (CABO 1992) requirements for one- and two-family dwellings.
\end{abstract}




\begin{abstract}
Alaska
Alaska's energy code, Building Energy Efficiency Standard, is promulgated by the Alaska Housing Finance Corporation and is mandatory only for state funded housing. The Alaska code subdivides the state into five climate regions. The thermal performance requirements for Regions $1,3,4$, and 5 are independent of fuel type. Region 2 has separate requirements for homes heated with natural gas. Natural gas is available in Anchorage and is frequently used in new homes. Because the natural gas requirements are less stringent than requirements for other fuel types, the natural gas requirements were used when making calculations to determine compliance with the 1992 MEC (CABO 1992).
\end{abstract}

Four methods are available for compliance with the state code: a prescriptive method, a performance method, a building budget method, and an energy rating method. All four methods are assumed to result in approximately the same energy consumption. The prescriptive path was used for this analysis because it was most readily utilized by our methodology. Other paths were presumed to be similar.

An overall $U$-value comparison was made for the state. The U-values from the five regions were averaged and weighted by housing starts. The basement wall insulation requirements are very different from the MEC requirements. The MEC basement wall requirements specify a $U$-value that is to be achieved for the full depth of the basement wall. The basement insulation requirements for the state code require that specific $R$-value levels of insulation be achieved for the upper half of the basement wall. The lower half of the basement wall may have half of the R-value of the upper wall. Additional perimeter insulation is required for a distance of $2 \mathrm{ft}$ underneath the basement floor. For this analysis, the additional insulation requirement underneath the basement floor was assumed to make up for the lower levels of insulation on the bottom half of the wall. Therefore, the basement requirements were modeled as the specified R-value for the upper half of the wall applied for the full depth of the basement wall.

Table AK. 1 shows the average overall envelope U-values for the state code and the $1992 \mathrm{MEC}$. The average overall U-value for the state code is lower than the average overall U-value for the MEC. Because it is within 5\% of the overall MEC U-value, the Alaska code has been classified as marginally meeting the 1992 MEC for one- and two-family dwellings. 
Table AK.1. Average Overall Envelope U-Values for Regions of Alaska

\begin{tabular}{|c|c|c||}
\hline Region & $\mathrm{U}_{\mathrm{o}}$ & Housing Starts (\%) \\
\hline 1 & 0.059 & 21 \\
\hline 2 & 0.066 & 72 \\
\hline 3 & 0.056 & 7 \\
\hline 4 & 0.054 & 0 \\
\hline 5 & 0.053 & 0 \\
\hline State Average & 0.064 & \\
\hline MEC Average & 0.068 & \\
\hline
\end{tabular}

Tables AK.2 and AK.3 show a more detailed comparison of the state code to the $1992 \mathrm{MEC}$ by the type of foundation insulation used and by envelope component. Table AK.2 also shows combined Uvalues, which are the overall envelope $U$-values based on foundation type, averaged together and weighted by the proportion of homes in the state with the given foundation type (percentages shown in parentheses). Table AK.3 shows the state average U-value for walls, ceilings, and floors over unheated spaces and the state average F-value for slab and basement walls.

Table AK.2. Average Overall Envelope U-Value by Foundation Type for Alaska

\begin{tabular}{|c|c|c|c|c|}
\hline Region & Slab (23\%) & $\begin{array}{c}\text { Floor Over Unheated } \\
\text { Space (77\%) }\end{array}$ & $\begin{array}{c}\text { Basement } \\
\text { Wall (0\%) }\end{array}$ & Combined \\
\hline 1 & 0.071 & 0.055 & 0.064 & 0.059 \\
\hline 2 & 0.075 & 0.063 & 0.070 & 0.066 \\
\hline 3 & 0.069 & 0.051 & 0.061 & 0.056 \\
\hline 4 & 0.068 & 0.050 & 0.060 & 0.054 \\
\hline 5 & 0.075 & 0.047 & 0.100 & 0.053 \\
\hline State Average & 0.074 & 0.061 & 0.068 & 0.064 \\
\hline MEC Average & 0.076 & 0.065 & 0.068 & 0.068 \\
\hline
\end{tabular}


Table AK.3. Average Envelope Component U-Values or F-Values for Alaska

\begin{tabular}{|c|c|c|c|c|c||}
\hline Region & $\begin{array}{c}\text { Wall } \\
\left(\mathrm{Btu} / \mathrm{h} \cdot \mathrm{ft}^{2} \bullet{ }^{\circ} \mathrm{F}\right)\end{array}$ & $\begin{array}{c}\text { Ceiling } \\
\left(\mathrm{Btu} / \mathrm{h} \bullet \mathrm{ft}^{2} \bullet{ }^{\circ} \mathrm{F}\right)\end{array}$ & $\begin{array}{c}\text { Floor } \\
\left(\mathrm{Btu} / \mathrm{h} \bullet \mathrm{ft}^{2} \bullet{ }^{\circ} \mathrm{F}\right)\end{array}$ & $\begin{array}{c}\text { Slab } \\
\left(\mathrm{Btu} / \mathrm{h} \bullet \mathrm{ft} \bullet{ }^{\circ} \mathrm{F}\right)\end{array}$ & $\begin{array}{c}\text { Basement } \\
\left(\mathrm{Btu} / \mathrm{h} \bullet \mathrm{ft}{ }^{\circ} \mathrm{F}\right)\end{array}$ \\
\hline 1 & 0.095 & 0.030 & 0.033 & 0.767 & 1.066 \\
\hline 2 & 0.104 & 0.030 & 0.047 & 0.767 & 1.182 \\
\hline 3 & 0.089 & 0.030 & 0.026 & 0.767 & 1.008 \\
\hline 4 & 0.086 & 0.030 & 0.026 & 0.767 & 1.008 \\
\hline 5 & 0.083 & 0.025 & 0.024 & 1.042 & 2.584 \\
\hline State Average & 0.101 & 0.030 & 0.043 & 0.767 & 1.146 \\
\hline MEC Average & 0.109 & 0.026 & 0.050 & 0.780 & 1.067 \\
\hline (a) Includes windows and doors. & & & & \\
\hline
\end{tabular}

The results of the duct analysis showed duct losses associated with the Alaska code requirements to be $3.6 \%$ compared to duct losses of $2.7 \%$ associated with the MEC requirements.

Tables AK.4 and AK.5 show the envelope requirements for the state code and for the 1992 MEC.

Table AK.4. Alaska State Code Envelope Requirements

\begin{tabular}{||c|c|c|c|c|c|c|c|c|c||}
\hline Region & $\begin{array}{c}\text { Ceiling } \\
\text { R-Value }\end{array}$ & $\begin{array}{c}\text { Wall } \\
\text { R-Value }\end{array}$ & $\begin{array}{c}\text { Window } \\
\text { U-Value }\end{array}$ & $\begin{array}{c}\text { Door } \\
\text { R-Value }\end{array}$ & $\begin{array}{c}\text { Floor } \\
\text { R-Value }\end{array}$ & $\begin{array}{c}\text { Basement } \\
\text { Wall } \\
\text { R-Value }\end{array}$ & $\begin{array}{c}\text { Basement } \\
\text { Depth }\end{array}$ & $\begin{array}{c}\text { Slab } \\
\text { R-Value }\end{array}$ & $\begin{array}{c}\text { Slab } \\
\text { Depth }\end{array}$ \\
\hline 1 & 38 & 21 & 0.33 & 5.31 & 30 & 15 & 8 & 10 & 2 \\
\hline 2 & 38 & 18 & 0.33 & 5.31 & 19 & 10 & 8 & 10 & 2 \\
\hline 3 & 38 & 25 & 0.33 & 7.00 & 38 & 19 & 8 & 10 & 2 \\
\hline 4 & 38 & 30 & 0.33 & 7.00 & 38 & 19 & 8 & 10 & 2 \\
\hline 5 & 52 & 35 & 0.33 & 7.00 & 43 & NA & NA & NA & NA \\
\hline
\end{tabular}


Table AK.5. 1992 MEC Envelope Requirements for Alaska

\begin{tabular}{|l|c|c|c|c|c|c||}
\hline & $\begin{array}{c}\text { Ceiling } \\
\text { U-Value }\end{array}$ & $\begin{array}{c}\text { Wall } \\
\text { U-Value }\end{array}$ & $\begin{array}{c}\text { Floor } \\
\text { U-Value }\end{array}$ & $\begin{array}{c}\text { Basement } \\
\text { U-Value }\end{array}$ & $\begin{array}{c}\text { Slab } \\
\text { R-Value }\end{array}$ & $\begin{array}{c}\text { Slab } \\
\text { Depth }\end{array}$ \\
\hline Anchorage & 0.026 & 0.11 & 0.05 & 0.06 & 8.2 & 4 \\
\hline Fairbanks & 0.026 & 0.10 & 0.05 & 0.06 & 10.5 & 4 \\
\hline Juneau & 0.026 & 0.11 & 0.05 & 0.06 & 7.1 & 4 \\
\hline Kenai & 0.026 & 0.11 & 0.05 & 0.06 & 8.7 & 4 \\
\hline
\end{tabular}

Table AK.6 shows the design information and housing starts for each of the cities used in the analysis.

Table AK.6. Design Information and Housing Starts for Alaska

\begin{tabular}{||l|c|c|c|c||}
\hline & HDD & $\begin{array}{c}\text { Design } \\
\text { Temperature }\end{array}$ & $\begin{array}{c}\text { Housing } \\
\text { Starts }\end{array}$ & Region \\
\hline Anchorage & 10,825 & -18 & 789 & 2 \\
\hline Fairbanks & 14,280 & -47 & 81 & 3 \\
\hline Juneau & 9,113 & 1 & 240 & 1 \\
\hline Kenai & 11,619 & -25 & 42 & 2 \\
\hline
\end{tabular}




\section{Arizona}

The Arizona Guidelines for Energy Conservation in New Building Construction are the staterecognized guidelines for energy conservation in new construction. Local governments have the option to adopt these guidelines as law. The Arizona code consists of a set of prescriptive path $U$-value requirements. Door U-value requirements are not given in the state code, so a U-value of 0.60 was assumed for the analysis. Window $U$-value requirements are not given, so a $U$-value of 1.18, representing single-pane aluminum windows, was assumed. An overall U-value analysis was performed.

Table AZ.1 shows the average overall envelope U-value for the state code and the 1992 MEC (CABO 1992). The average overall $U$-value for the state code is higher than the average overall MEC U-value. Therefore, the Arizona guidelines do not meet the $1992 \mathrm{MEC}$ requirements for one- and two-family dwellings.

Table AZ.1. Average Overall Envelope U-Value for Arizona

\begin{tabular}{|l|c|}
\hline & $\mathrm{U}_{0}$ \\
\hline State Average & 0.138 \\
& $(13 \%$ above MEC average $)$ \\
\hline MEC Average & 0.122 \\
\hline
\end{tabular}

Tables AZ.2 and AZ.3 show a more detailed comparison of the state guidelines to the 1992 MEC by the type of foundation insulation used and by envelope component. Table AZ.2 also shows combined $U$-values, which are the average overall envelope $U$-values based on foundation type, averaged and weighted by the proportion of homes in the state with the given foundation type (percentages shown in parentheses). Table AZ.3 shows the state average U-value for walls, ceilings, and floors over unheated spaces and the state average F-value for slab and basement walls.

Table AZ.2. Average Overall Envelope U-Values by Foundation Type for Arizona

\begin{tabular}{|l|c|c|c|c||}
\hline & Slab (76\%) & $\begin{array}{c}\text { Floor Over Unheated } \\
\text { Space (21\%) }\end{array}$ & $\begin{array}{c}\text { Basement } \\
\text { Wall (2\%) }\end{array}$ & Combined \\
\hline State Average & 0.144 & 0.121 & 0.154 & 0.138 \\
\hline MEC Average & 0.126 & 0.113 & 0.117 & 0.122 \\
\hline
\end{tabular}


Table AZ.3. Average Envelope Component U-Values or F-Values

\begin{tabular}{|l|c|c|c|c|c||}
\hline & $\begin{array}{c}\text { Ceiling } \\
\left(\mathrm{Btu} / \mathrm{h} \bullet \mathrm{ft}^{2} \bullet{ }^{\circ} \mathrm{F}\right)\end{array}$ & $\begin{array}{c}\mathrm{Wall}^{(\mathrm{a})} \\
\left(\mathrm{Btu} / \mathrm{h} \bullet \mathrm{ft}^{2} \bullet{ }^{\circ} \mathrm{F}\right)\end{array}$ & $\begin{array}{c}\text { Slab } \\
\left(\mathrm{Btu} / \mathrm{h} \bullet \mathrm{ft} \bullet{ }^{\circ} \mathrm{F}\right)\end{array}$ & $\begin{array}{c}\text { Floors } \\
\left(\mathrm{Btu} / \mathrm{h} \bullet{ }^{\circ} \mathrm{F} \bullet \mathrm{ft}^{2}\right)\end{array}$ & $\begin{array}{c}\text { Basement } \\
\left(\mathrm{Btu} / \mathrm{h} \bullet \mathrm{ft} \bullet{ }^{\circ} \mathrm{F}\right)\end{array}$ \\
\hline $\begin{array}{l}\text { State } \\
\text { Average }\end{array}$ & 0.040 & 0.252 & 1.042 & 0.040 & 2.584 \\
\hline $\begin{array}{l}\text { MEC } \\
\text { Average }\end{array}$ & 0.045 & 0.206 & 0.996 & 0.067 & 1.670 \\
\hline (a) Includes windows and doors.
\end{tabular}

Tables AZ.4 and AZ.5 show the envelope requirements for the state code and for the 1992 MEC.

Table AZ.4. Arizona State Code Envelope Requirements

\begin{tabular}{||l|c|}
\hline Ceiling U-Value & 0.04 \\
\hline Wall U-Value & 0.08 \\
\hline Window U-Value & 1.18 \\
\hline Door U-Value & 0.60 \\
\hline Floor U-Value & 0.04 \\
\hline Basement Wall R-Value & 0 \\
\hline Basement Depth & - \\
\hline Slab R-Value & 0 \\
\hline Slab Depth & - \\
\hline
\end{tabular}

Table AZ.5. 1992 MEC Envelope Requirements for Arizona

\begin{tabular}{|l|c|c|c|c|c|c||}
\hline & $\begin{array}{c}\text { Ceiling } \\
\text { U-Value }\end{array}$ & $\begin{array}{c}\text { Wall } \\
\text { U-Value }\end{array}$ & $\begin{array}{c}\text { Floor } \\
\text { U-Value }\end{array}$ & $\begin{array}{c}\text { Basement } \\
\text { U-Value }\end{array}$ & $\begin{array}{c}\text { Slab } \\
\text { R-Value }\end{array}$ & $\begin{array}{c}\text { Slab } \\
\text { Depth }\end{array}$ \\
\hline Casa Grande & 0.0472 & 0.216 & 0.07 & 0.168 & 0 & - \\
\hline Douglas & 0.0414 & 0.175 & 0.05 & 0.140 & 4 & 2 \\
\hline Flagstaff & 0.0260 & 0.110 & 0.05 & 0.093 & 5.8 & 4 \\
\hline Mesa & 0.0471 & 0.216 & 0.07 & 0.168 & 0 & - \\
\hline
\end{tabular}


Table AZ.5. (contd)

\begin{tabular}{|l|c|c|c|c|c|c||}
\hline \hline & $\begin{array}{c}\text { Ceiling } \\
\text { U-Value }\end{array}$ & $\begin{array}{c}\text { Wall } \\
\text { U-Value }\end{array}$ & $\begin{array}{c}\text { Floor } \\
\text { U-Value }\end{array}$ & $\begin{array}{c}\text { Basement } \\
\text { U-Value }\end{array}$ & $\begin{array}{c}\text { Slab } \\
\text { R-Value }\end{array}$ & $\begin{array}{c}\text { Slab } \\
\text { Depth }\end{array}$ \\
\hline Nogales & 0.0408 & 0.174 & 0.05 & 0.137 & 4 & 2 \\
\hline Phoenix & 0.0479 & 0.222 & 0.07 & - & 0 & - \\
\hline Prescott & 0.0310 & 0.142 & 0.05 & 0.099 & 4 & 2 \\
\hline Tempe & 0.0468 & 0.214 & 0.07 & 0.166 & 0 & - \\
\hline Tucson & 0.0465 & 0.211 & 0.07 & 0.165 & 0 & - \\
\hline Yuma & 0.0500 & 0.241 & 0.08 & - & 0 & - \\
\hline
\end{tabular}

Table AZ.6 shows the design information and housing starts for each of the cities used in the analysis.

Table AZ.6. Design Information and Housing Starts for Arizona

\begin{tabular}{||l|c|c|c||}
\hline & HDD & $\begin{array}{c}\text { Design } \\
\text { Temperature }\end{array}$ & $\begin{array}{c}\text { Housing } \\
\text { Starts }\end{array}$ \\
\hline Casa Grande & 1,593 & 41 & 600 \\
\hline Douglas & 2,801 & 31 & 2,838 \\
\hline Flagstaff & 7,256 & 4 & 780 \\
\hline Mesa & 1,600 & 36 & 2,421 \\
\hline Nogales & 2,915 & 32 & 0 \\
\hline Phoenix & 1,444 & 34 & 6,008 \\
\hline Prescott & 4,951 & 9 & 1,535 \\
\hline Tempe & 1,657 & 30 & 13,296 \\
\hline Tucson & 1,737 & 32 & 3,872 \\
\hline Yuma & 983 & 39 & 0 \\
\hline \hline
\end{tabular}




\section{Arkansas}

Arkansas has adopted the 1979 Arkansas Rules and Regulations for Energy Efficiency Standards for New Building Construction, which is mandatory for local jurisdictions that have adopted a building code. The Arkansas code gives $\mathrm{R}$-value requirements, which were converted to $\mathrm{U}$-value requirements and then compared to the 1992 MEC (CABO 1992) component-by-component.

Table AR.1 shows the state code and MEC requirements. For every envelope component, the 1992 MEC U-values are lower and the slab R-values higher than the state code's values, clearly indicating that the MEC is more stringent than the state code. Therefore, the state code does not meet the 1992 MEC requirements for one- and two-family dwellings.

Table AR.1. Arkansas State Code and 1992 MEC Envelope Requirements

\begin{tabular}{||l|c|c||}
\hline \multicolumn{1}{|c|}{ Component } & State Code U-Values & MEC U-Values \\
\hline Ceiling & 0.05 & $0.038-0.042$ \\
\hline Wall & $0.24-0.27$ & $0.15-0.19$ \\
\hline Floor & $0.11-0.22$ & 0.05 \\
\hline Slab (R-Value) & $2.49-3.52$ & 4 \\
\hline
\end{tabular}




\section{California}

California's energy code, Energy Efficiency Standards for Residential and Non-Residential Buildings, is mandatory for all new residential construction. The California code has different requirements for electric and nonelectric homes. The state code subdivides the state into 16 climate regions. Each region has several R-value prescriptive paths that may be used for compliance. Package $B$, which is a nonelectric path, was used to compare the state code to the 1992 MEC (CABO 1992). Path B was chosen because it has no shading coefficient requirements, restrictions on glazing orientation, or thermal mass requirements, making comparisons with the MEC requirements more straightforward: Path $\mathrm{B}$ was also chosen because it is less stringent than the electric code. The other nonelectric prescriptive paths were assumed to result in approximately equivalent energy use. An overall U-value comparison was made for the state. The U-values for the 16 regions were averaged and weighted by housing starts. Door U-value requirements are not given in the state code, so a $U$-value of 0.60 was assumed for the analysis.

Table CA.1 shows the average overall envelope U-values for the state nonelectric code and the 1992 MEC. The state nonelectric average overall U-value is much lower than the MEC average overall U-value. Therefore, the state nonelectric code meets or exceeds the $1992 \mathrm{MEC}$. Because the electric code is much more stringent than the nonelectric code, it also meets the 1992 MEC. Therefore, the Califomia code meets or exceeds the 1992 MEC requirements for one- and two-family dwellings. 
Table CA.1. Average Overall Envelope U-Values for Regions of California

\begin{tabular}{|c|c|c|}
\hline Region & $\mathrm{U}_{\mathrm{o}}$ & Housing Starts (\%) \\
\hline 1 & 0.096 & 0.2 \\
\hline 2 & 0.096 & 8.6 \\
\hline 3 & 0.096 & 6.6 \\
\hline 4 & 0.096 & 2.9 \\
\hline 5 & 0.096 & 1.0 \\
\hline 6 & 0.096 & 10.8 \\
\hline 7 & 0.103 & 4.2 \\
\hline 8 & 0.096 & 6.3 \\
\hline 9 & 0.096 & 3.3 \\
\hline 10 & 0.096 & 17.4 \\
\hline 11 & 0.096 & 4.3 \\
\hline 12 & 0.096 & 18.8 \\
\hline 13 & 0.096 & 13.0 \\
\hline 14 & 0.094 & 1.1 \\
\hline 15 & 0.094 & 0.9 \\
\hline 16 & 0.094 & 0.5 \\
\hline State Average & $\begin{array}{c}0.096 \\
\text { (15\% below MEC average) }\end{array}$ & \\
\hline MEC Average & 0.113 & \\
\hline
\end{tabular}

Tables CA.2 and CA.3 show a more detailed comparison of the state code to the 1992 MEC by the type of foundation insulation used and by envelope component. Table CA.2 also shows combined Uvalues, which are the overall envelope $U$-values based on foundation type, averaged together and weighted by the proportion of homes in the state with the given foundation type (percentages shown in parentheses). Table CA.3 shows the state average U-value for walls, ceilings, and floors over unheated spaces and the state average F-value for slab and basement walls. 
Table CA.2. Average Overall Envelope U-Values by Foundation Type for California

\begin{tabular}{|c|c|c|c|c|}
\hline Region & Slab (80\%) & $\begin{array}{l}\text { Floor over Unheated } \\
\text { Space }(19 \%)\end{array}$ & $\begin{array}{l}\text { Basement } \\
\text { Wall (0\%) }\end{array}$ & Combined \\
\hline 1 & 0.099 & 0.085 & 0.082 & 0.096 \\
\hline 2 & 0.099 & 0.085 & 0.082 & 0.096 \\
\hline 3 & 0.099 & 0.085 & 0.082 & 0.096 \\
\hline 4 & 0.099 & 0.085 & 0.082 & 0.096 \\
\hline 5 & 0.099 & 0.085 & 0.082 & 0.096 \\
\hline 6 & 0.099 & 0.085 & 0.082 & 0.096 \\
\hline 7 & 0.106 & 0.096 & 0.090 & 0.103 \\
\hline 8 & 0.099 & 0.085 & 0.082 & 0.096 \\
\hline 9 & 0.099 & 0.085 & 0.082 & 0.096 \\
\hline 10 & 0.099 & 0.085 & 0.082 & 0.096 \\
\hline 11 & 0.099 & 0.085 & 0.082 & 0.096 \\
\hline 12 & 0.099 & 0.085 & 0.082 & 0.096 \\
\hline 13 & 0.099 & 0.085 & 0.082 & 0.096 \\
\hline 14 & 0.098 & 0.083 & 0.081 & 0.094 \\
\hline 15 & 0.098 & 0.083 & 0.081 & 0.094 \\
\hline 16 & 0.098 & 0.083 & 0.081 & 0.094 \\
\hline State Average & 0.099 & 0.085 & 0.082 & 0.096 \\
\hline MEC Average & 0.117 & 0.105 & 0.108 & 0.113 \\
\hline
\end{tabular}


Table CA.3. Average Envelope Component U-Values or F-Values for California

\begin{tabular}{|c|c|c|c|c|c|}
\hline Region & $\begin{array}{c}\text { Wall } \\
\left(\mathrm{Btu} / \mathrm{h} \cdot \mathrm{ft}^{2} \bullet{ }^{\circ} \mathrm{F}\right)\end{array}$ & $\begin{array}{c}\text { Ceiling } \\
\left(\mathrm{Btu} / \mathrm{h} \cdot \mathrm{ft}^{2} \bullet^{\circ} \mathrm{F}\right)\end{array}$ & $\begin{array}{c}\text { Floor } \\
\left(\mathrm{Btu} / \mathrm{h} \cdot \mathrm{ft}^{2} \bullet^{\circ} \mathrm{F}\right)\end{array}$ & $\begin{array}{c}\text { Slab } \\
\left(\mathrm{Btu} / \mathrm{h} \cdot \mathrm{ft} \bullet^{\circ} \mathrm{F}\right)\end{array}$ & $\begin{array}{c}\text { Basement } \\
\left(\mathrm{Btu} / \mathrm{h} \cdot \mathrm{ft} \bullet^{\circ} \mathrm{F}\right)\end{array}$ \\
\hline 1 & 0.156 & 0.035 & 0.047 & 0.851 & 1.008 \\
\hline 2 & 0.156 & 0.035 & 0.047 & 0.851 & 1.008 \\
\hline 3 & 0.156 & 0.035 & 0.047 & 0.851 & 1.008 \\
\hline 4 & 0.156 & 0.035 & 0.047 & 0.851 & 1.008 \\
\hline 5 & 0.156 & 0.035 & 0.047 & 0.851 & 1.008 \\
\hline 6 & 0.156 & 0.035 & 0.047 & 0.851 & 1.008 \\
\hline 7 & 0.173 & 0.035 & 0.064 & 0.851 & 1.101 \\
\hline 8 & 0.156 & 0.035 & 0.047 & 0.851 & 1.008 \\
\hline 9 & 0.156 & 0.035 & 0.047 & 0.851 & 1.008 \\
\hline 10 & 0.156 & 0.035 & 0.047 & 0.851 & 1.008 \\
\hline 11 & 0.156 & 0.035 & 0.047 & 0.851 & 1.008 \\
\hline 12 & 0.156 & 0.035 & 0.047 & 0.851 & 1.008 \\
\hline 13 & 0.156 & 0.035 & 0.047 & 0.851 & 1.008 \\
\hline 14 & 0.156 & 0.03 & 0.047 & 0.851 & 1.008 \\
\hline 15 & 0.156 & 0.03 & 0.047 & 0.851 & 1.008 \\
\hline 16 & 0.156 & 0.03 & 0.047 & 0.851 & 1.008 \\
\hline State Average & 0.157 & 0.035 & 0.048 & 0.851 & 1.012 \\
\hline MEC Average & 0.191 & 0.044 & 0.061 & 0.91 & 1.505 \\
\hline
\end{tabular}

The results of the duct analysis showed duct losses associated with the Califomia code requirements to be $5.4 \%$ compared to duct losses of $3.4 \%$ associated with the $1992 \mathrm{MEC}$ requirement. 
Tables CA.4 and CA.5 show the envelope requirements for the state code and for the MEC.

Table CA.4. California State Code Envelope Requirements

\begin{tabular}{||c|c|c|c|c|c|c|c|c|c||}
\hline Region & $\begin{array}{c}\text { Ceiling } \\
\text { R-Value }\end{array}$ & $\begin{array}{c}\text { Wall } \\
\text { R-Value }\end{array}$ & $\begin{array}{c}\text { Window } \\
\text { U-Value }\end{array}$ & $\begin{array}{c}\text { Door } \\
\text { U-Value }\end{array}$ & $\begin{array}{c}\text { Floor } \\
\text { R-Value }\end{array}$ & $\begin{array}{c}\text { Basement } \\
\text { Wall } \\
\text { R-Value }\end{array}$ & $\begin{array}{c}\text { Basement } \\
\text { Depth }\end{array}$ & $\begin{array}{c}\text { Slab } \\
\text { R-Value }\end{array}$ & $\begin{array}{c}\text { Slab } \\
\text { Depth }\end{array}$ \\
\hline 1 & 30 & 19 & 0.65 & 0.60 & 19 & 19 & 8 & 7 & 1.33 \\
\hline 2 & 30 & 19 & 0.65 & 0.60 & 19 & 19 & 8 & 7 & 1.33 \\
\hline 3 & 30 & 19 & 0.65 & 0.60 & 19 & 19 & 8 & 7 & 1.33 \\
\hline 4 & 30 & 19 & 0.65 & 0.60 & 19 & 19 & 8 & 7 & 1.33 \\
\hline 5 & 30 & 19 & 0.65 & 0.60 & 19 & 19 & 8 & 7 & 1.33 \\
\hline 6 & 30 & 19 & 0.65 & 0.60 & 19 & 19 & 8 & 7 & 1.33 \\
\hline 7 & 30 & 13 & 0.65 & 0.60 & 13 & 13 & 8 & 7 & 1.33 \\
\hline 8 & 30 & 19 & 0.65 & 0.60 & 19 & 19 & 8 & 7 & 1.33 \\
\hline 9 & 30 & 19 & 0.65 & 0.60 & 19 & 19 & 8 & 7 & 1.33 \\
\hline 10 & 30 & 19 & 0.65 & 0.60 & 19 & 19 & 8 & 7 & 1.33 \\
\hline 11 & 30 & 19 & 0.65 & 0.60 & 19 & 19 & 8 & 7 & 1.33 \\
\hline 12 & 30 & 19 & 0.65 & 0.60 & 19 & 19 & 8 & 7 & 1.33 \\
\hline 13 & 30 & 19 & 0.65 & 0.60 & 19 & 19 & 8 & 7 & 1.33 \\
\hline 14 & 38 & 19 & 0.65 & 0.60 & 19 & 19 & 8 & 7 & 1.33 \\
\hline 15 & 38 & 19 & 0.65 & 0.60 & 19 & 19 & 8 & 7 & 1.33 \\
\hline 16 & 38 & 19 & 0.65 & 0.60 & 19 & 19 & 8 & 7 & 1.33 \\
\hline \hline
\end{tabular}

Table CA.5. 1992 MEC Envelope Requirements for California

\begin{tabular}{|l|c|c|c|c|c|c||}
\hline & $\begin{array}{c}\text { Ceiling } \\
\text { U-Value }\end{array}$ & $\begin{array}{c}\text { Wall } \\
\text { U-Value }\end{array}$ & $\begin{array}{c}\text { Floor } \\
\text { U-Value }\end{array}$ & $\begin{array}{c}\text { Basement } \\
\text { U-Value }\end{array}$ & $\begin{array}{c}\text { Slab } \\
\text { R-Value }\end{array}$ & $\begin{array}{c}\text { Slab } \\
\text { Depth }\end{array}$ \\
\hline Antioch & 0.0403 & 0.172 & 0.05 & 0.135 & 4 & 2 \\
\hline Bakersfield & 0.0446 & 0.195 & 0.07 & 0.155 & 0 & - \\
\hline Barstow & 0.0424 & 0.179 & 0.05 & 0.145 & 4 & 2 \\
\hline Berkeley & 0.0406 & 0.173 & 0.05 & 0.136 & 4 & 2 \\
\hline Burbank & 0.0467 & 0.213 & 0.07 & 0.166 & 0 & - \\
\hline Chico & 0.0410 & 0.174 & 0.05 & 0.138 & 4 & 2 \\
\hline Chula Vista & 0.0448 & 0.197 & 0.07 & 0.157 & 0 & - \\
\hline
\end{tabular}


Table CA.5. (contd)

\begin{tabular}{||l|c|c|c|c|c|c||}
\hline & $\begin{array}{c}\text { Ceiling } \\
\text { U-Value }\end{array}$ & $\begin{array}{c}\text { Wall } \\
\text { U-Value }\end{array}$ & $\begin{array}{c}\text { Floor } \\
\text { U-Value }\end{array}$ & $\begin{array}{c}\text { Basement } \\
\text { U-Value }\end{array}$ & $\begin{array}{c}\text { Slab } \\
\text { R-Value }\end{array}$ & $\begin{array}{c}\text { Slab } \\
\text { Depth }\end{array}$ \\
\hline Claremont & 0.0449 & 0.198 & 0.07 & 0.157 & 0 & - \\
\hline Concord & 0.0416 & 0.176 & 0.05 & 0.141 & 4 & -2 \\
\hline Corona & 0.0462 & 0.208 & 0.07 & 0.163 & 0 & - \\
\hline Culver City & 0.0475 & 0.219 & 0.07 & 0.170 & 0 & - \\
\hline Davis & 0.0411 & 0.175 & 0.05 & 0.139 & 4 & 2 \\
\hline El Centro & 0.0490 & 0.231 & 0.07 & - & 0 & - \\
\hline Escondido & 0.0451 & 0.200 & 0.07 & 0.158 & 0 & - \\
\hline Eureka & 0.0321 & 0.145 & 0.05 & 0.099 & 4.1 & 2 \\
\hline Fairfield & 0.0419 & 0.177 & 0.05 & 0.142 & 4 & 2 \\
\hline Fontana & 0.0475 & 0.219 & 0.07 & 0.170 & 0 & - \\
\hline Fresno & 0.0421 & 0.178 & 0.05 & 0.143 & 4 & 2 \\
\hline Hanford & 0.0417 & 0.176 & 0.05 & 0.141 & 4 & 2 \\
\hline Indio & 0.0497 & 0.238 & 0.07 & - & 0 & - \\
\hline Laguna Beach & 0.0441 & 0.191 & 0.07 & 0.153 & 0 & - \\
\hline La Mesa & 0.0473 & 0.217 & 0.07 & 0.168 & 0 & - \\
\hline Lancaster & 0.0467 & 0.213 & 0.07 & 0.166 & 0 & - \\
\hline Livermore & 0.0403 & 0.172 & 0.05 & 0.135 & 4 & 2 \\
\hline Lodi & 0.0411 & 0.174 & 0.05 & 0.138 & 4 & 2 \\
\hline Lompoc & 0.0409 & 0.174 & 0.05 & 0.137 & 4 & 2 \\
\hline Long Beach & 0.0477 & 0.221 & 0.07 & - & 0 & - \\
\hline Los Angeles & 0.0471 & 0.216 & 0.07 & 0.168 & 0 & - \\
\hline Los Banos & 0.0422 & 0.178 & 0.05 & 0.144 & 4 & 2 \\
\hline Los Gatos & 0.0416 & 0.176 & 0.05 & 0.141 & 4 & 2 \\
\hline Madera & 0.0419 & 0.177 & 0.05 & 0.143 & 4 & 2 \\
\hline Merced & 0.0420 & 0.178 & 0.05 & 0.143 & 4 & 2 \\
\hline Modesto & 0.0420 & 0.177 & 0.05 & 0.143 & 4 & 2 \\
\hline Monterey & 0.0396 & 0.170 & 0.05 & 0.131 & 4 & 2 \\
\hline Napa & 0.0416 & 0.176 & 0.05 & 0.141 & 4 & 2 \\
\hline Newport Beach & 0.0454 & 0.202 & 0.07 & 0.159 & 0 & - \\
\hline
\end{tabular}


Table CA.5. (contd)

\begin{tabular}{||l|c|c|c|c|c|c||}
\hline \hline & $\begin{array}{c}\text { Ceiling } \\
\text { U-Value }\end{array}$ & $\begin{array}{c}\text { Wall } \\
\text { U-Value }\end{array}$ & $\begin{array}{c}\text { Floor } \\
\text { U-Value }\end{array}$ & $\begin{array}{c}\text { Basement } \\
\text { U-Value }\end{array}$ & $\begin{array}{c}\text { Slab } \\
\text { R-Value }\end{array}$ & $\begin{array}{c}\text { Slab } \\
\text { Depth }\end{array}$ \\
\hline Oakland & 0.0410 & 0.174 & 0.05 & 0.138 & 4 & 2 \\
\hline Oceanside & 0.0451 & 0.200 & 0.07 & 0.158 & 0 & - \\
\hline Oxnard & 0.0449 & 0.197 & 0.07 & 0.157 & 0 & - \\
\hline Palm Springs & 0.0495 & 0.236 & 0.07 & - & 0 & - \\
\hline Palo Alto & 0.0409 & 0.174 & 0.05 & 0.138 & 4 & 2 \\
\hline Pasadena & 0.0473 & 0.218 & 0.07 & 0.169 & 0 & - \\
\hline Petaluma & 0.0406 & 0.173 & 0.05 & 0.136 & 4 & 2 \\
\hline Pomona & 0.0453 & 0.201 & 0.07 & 0.159 & 0 & - \\
\hline Porterville & 0.0430 & 0.182 & 0.07 & 0.148 & 0 & - \\
\hline Redding & 0.0426 & 0.179 & 0.05 & 0.146 & 4 & 2 \\
\hline Redlands & 0.0452 & 0.200 & 0.07 & 0.158 & 0 & - \\
\hline Redwood City & 0.0423 & 0.178 & 0.05 & 0.144 & 4 & 2 \\
\hline Richmond & 0.0419 & 0.177 & 0.05 & 0.142 & 4 & 2 \\
\hline Riverside & 0.0460 & 0.207 & 0.07 & 0.163 & 0 & - \\
\hline Sacramento & 0.0415 & 0.176 & 0.05 & 0.140 & 4 & 2 \\
\hline Salinas & 0.0387 & 0.167 & 0.05 & 0.127 & 4 & 2 \\
\hline San Bernardino & 0.0463 & 0.209 & 0.07 & 0.164 & 0 & - \\
\hline San Diego & 0.0486 & 0.229 & 0.07 & - & 0 & - \\
\hline San Francisco & 0.0396 & 0.170 & 0.05 & 0.131 & 4 & 2 \\
\hline San Gabriel & 0.0474 & 0.219 & 0.07 & 0.169 & 0 & - \\
\hline San Jose & 0.0431 & 0.182 & 0.07 & 0.148 & 0 & - \\
\hline San Luis Obispo & 0.0428 & 0.180 & 0.05 & 0.147 & 4 & 2 \\
\hline San Rafael & 0.0431 & 0.182 & 0.07 & 0.148 & 0 & - \\
\hline Santa Ana & 0.0479 & 0.223 & 0.07 & - & 0 & - \\
\hline Santa Barbara & 0.0452 & 0.200 & 0.07 & 0.158 & 0 & - \\
\hline Santa Cruz & 0.0397 & 0.170 & 0.05 & 0.132 & 4 & 2 \\
\hline Santa Maria & 0.0401 & 0.171 & 0.05 & 0.134 & 4 & 2 \\
\hline Santa Monica & 0.0458 & 0.205 & 0.07 & 0.161 & 0 & - \\
\hline Santa Paula & 0.0451 & 0.199 & 0.07 & 0.158 & 0 & - \\
\hline
\end{tabular}


Table CA.5. (contd)

\begin{tabular}{||l|c|c|c|c|c|c||}
\hline & $\begin{array}{c}\text { Ceiling } \\
\text { U-Value }\end{array}$ & $\begin{array}{c}\text { Wall } \\
\text { U-Value }\end{array}$ & $\begin{array}{c}\text { Floor } \\
\text { U-Value }\end{array}$ & $\begin{array}{c}\text { Basement } \\
\text { U-Value }\end{array}$ & $\begin{array}{c}\text { Slab } \\
\text { R-Value }\end{array}$ & $\begin{array}{c}\text { Slab } \\
\text { Depth }\end{array}$ \\
\hline Santa Rosa & 0.0405 & 0.173 & 0.05 & 0.135 & 4 & 2 \\
\hline Stockton & 0.0420 & 0.177 & 0.05 & 0.143 & 4 & 2 \\
\hline Torrance & 0.0465 & 0.211 & 0.07 & 0.165 & 0 & - \\
\hline Tracy & 0.0418 & 0.177 & 0.05 & 0.142 & 4 & 2 \\
\hline Tustin & 0.0459 & 0.206 & 0.07 & 0.162 & 0 & - \\
\hline Upland & 0.0444 & 0.193 & 0.07 & 0.154 & 0 & - \\
\hline Vacaville & 0.0414 & 0.176 & 0.05 & 0.140 & 4 & 2 \\
\hline Visalia & 0.0430 & 0.182 & 0.07 & 0.148 & 0 & - \\
\hline Watsonville & 0.0387 & 0.167 & 0.05 & 0.127 & 4 & 2 \\
\hline Woodland & 0.0418 & 0.177 & 0.05 & 0.142 & 4 & 2 \\
\hline Yorba Linda & 0.0469 & 0.214 & 0.07 & 0.167 & 0 & - \\
\hline \hline
\end{tabular}

Table CA.6 shows the design information and housing starts for each of the cities used in the analysis.

Table CA.6. Design Information and Housing Starts for California

\begin{tabular}{||l|c|c|c|c||}
\hline & HDD & $\begin{array}{c}\text { Design } \\
\text { Temperature }\end{array}$ & $\begin{array}{c}\text { Housing } \\
\text { Starts }\end{array}$ & Region \\
\hline Antioch & 3,015 & 27 & 3,362 & 12 \\
\hline Bakersfield & 2,127 & 32 & 4,534 & 13 \\
\hline Barstow & 2,585 & 29 & 56 & 14 \\
\hline Berkeley & 2,957 & 23 & 0 & 3 \\
\hline Burbank & 1,681 & 39 & 174 & 1 \\
\hline Chico & 2,881 & 30 & 2,693 & 11 \\
\hline Chula Vista & 2,079 & 35 & 569 & 7 \\
\hline Claremont & 2,054 & 28 & 170 & 9 \\
\hline Concord & 2,752 & 27 & 144 & 12 \\
\hline
\end{tabular}

A. 17 
Table CA.6. (contd)

\begin{tabular}{||l|c|c|c|c||}
\hline \hline & HDD & $\begin{array}{c}\text { Design } \\
\text { Temperature }\end{array}$ & $\begin{array}{c}\text { Housing } \\
\text { Starts }\end{array}$ & Region \\
\hline Corona & 1,801 & 30 & 7,111 & 10 \\
\hline Culver City & 1,515 & 31 & 6 & 8 \\
\hline Davis & 2,847 & 19 & 477 & 12 \\
\hline El Centro & 1,218 & 36 & 582 & 15 \\
\hline Escondido & 2,012 & 41 & 2,364 & 10 \\
\hline Eureka & 4,729 & 33 & 523 & 7 \\
\hline Fairfield & 2,693 & 32 & 532 & 12 \\
\hline Fontana & 1,520 & 31 & 576 & 10 \\
\hline Fresno & 2,649 & 30 & 5,073 & 13 \\
\hline Hanford & 2,737 & 24 & 562 & 13 \\
\hline Indio & 1,059 & 35 & 262 & 15 \\
\hline Laguna Beach & 2,225 & 43 & 52 & 6 \\
\hline La Mesa & 1,571 & 29 & 19 & 7 \\
\hline Lancaster & 1,681 & 39 & 1,039 & 14 \\
\hline Livermore & 3,015 & 27 & 335 & 12 \\
\hline Lodi & 2,863 & 20 & 350 & 12 \\
\hline Lompoc & 2,896 & 38 & 92 & 5 \\
\hline Long Beach & 1,485 & 43 & 2,639 & 6 \\
\hline Los Angeles & 1,595 & 43 & 1,087 & 9 \\
\hline Los Banos & 2,618 & 21 & 1,365 & 12 \\
\hline Los Gatos & 2,746 & 28 & 1,040 & 4 \\
\hline Madera & 2,678 & 31 & 330 & 13 \\
\hline Merced & 2,658 & 31 & 401 & 12 \\
\hline Modesto & 2,673 & 30 & 1,741 & 12 \\
\hline Monterey & 3,177 & 38 & 44 & 3 \\
\hline
\end{tabular}

A. 18 
Table CA.6. (contd)

\begin{tabular}{||l|c|c|c|c||}
\hline & HDD & $\begin{array}{c}\text { Design } \\
\text { Temperature }\end{array}$ & $\begin{array}{c}\text { Housing } \\
\text { Starts }\end{array}$ & Region \\
\hline Napa & 2,752 & 32 & 408 & 2 \\
\hline Newport Beach & 1,959 & 27 & 108 & 6 \\
\hline Oakland & 2,880 & 36 & 2,814 & 3 \\
\hline Oceanside & 2,012 & 43 & 567 & 7 \\
\hline Oxnard & 2,070 & 36 & 1,808 & 6 \\
\hline Palm Springs & 1,109 & 35 & 21 & 15 \\
\hline Palo Alto & 2,893 & 34 & 57 & 4 \\
\hline Pasadena & 1,556 & 35 & 473 & 9 \\
\hline Petaluma & 2,961 & 29 & 1,603 & 2 \\
\hline Pomona & 1,973 & 29 & 133 & 9 \\
\hline Porterville & 2,460 & 31 & 269 & 13 \\
\hline Redding & 2,548 & 31 & 1,525 & 11 \\
\hline Redlands & 1,995 & 33 & 5,830 & 10 \\
\hline Redwood City & 2,602 & 22 & 887 & 3 \\
\hline Richmond & 2,688 & 36 & 215 & 3 \\
\hline Riverside & 1,823 & 32 & 588 & 10 \\
\hline Sacramento & 2,775 & 32 & 3,858 & 12 \\
\hline Salinas & 3,358 & 32 & 481 & 3 \\
\hline San Bernardino & 1,779 & 29 & 465 & 10 \\
\hline San Diego & 1,284 & 44 & 2,891 & 7 \\
\hline San Francisco & 3,164 & 38 & 1,432 & 3 \\
\hline San Gabriel & 1,537 & 32 & 76 & 9 \\
\hline San Jose & 2,442 & 36 & 1,757 & 4 \\
\hline San Luis Obispo & 2,503 & 23 & 574 & 5 \\
\hline San Rafael & 2,447 & 34 & 313 & 2 \\
\hline
\end{tabular}

A. 19 
Table CA.6. (contd)

\begin{tabular}{||l|c|c|c|c||}
\hline & HDD & $\begin{array}{c}\text { Design } \\
\text { Temperature }\end{array}$ & $\begin{array}{c}\text { Housing } \\
\text { Starts }\end{array}$ & Region \\
\hline Santa Ana & 1,434 & 39 & 63 & 8 \\
\hline Santa Barbara & 1,996 & 36 & 134 & 6 \\
\hline Santa Cruz & 3,141 & 38 & 588 & 3 \\
\hline Santa Maria & 3,064 & 33 & 273 & 5 \\
\hline Santa Monica & 1,873 & 43 & 5,622 & 6 \\
\hline Santa Paula & 2,030 & 35 & 1,251 & 9 \\
\hline Santa Rosa & 2,983 & 29 & 6,054 & 2 \\
\hline Stockton & 2,676 & 30 & 1,598 & 12 \\
\hline Torrance & 1,719 & 31 & 182 & 6 \\
\hline Tracy & 2,708 & 25 & 1,397 & 12 \\
\hline Tustin & 1,860 & 40 & 5,898 & 8 \\
\hline Upland & 2,177 & 26 & 0 & 10 \\
\hline Vacaville & 2,790 & 18 & 1,478 & 12 \\
\hline Visalia & 2,462 & 30 & 1,567 & 13 \\
\hline Watsonville & 3,358 & 32 & 349 & 13 \\
\hline Woodland & 2,711 & 24 & 1,212 & 12 \\
\hline Yorba Linda & 1,647 & 30 & 136 & 8 \\
\hline \hline
\end{tabular}




\section{Colorado}

The Colorado State Residential Building Energy Conservation Standard is the state energy code for Colorado. The Colorado code or a more stringent energy code must be adopted by cities or counties that have a building code. The state code was compared to the 1992 MEC (CABO 1992) by comparing each envelope component.

The state code and 1992 MEC envelope requirements are given in Table CO.1. The MEC U-values are consistently lower and the slab R-values higher than the state code's values, indicating that the MEC is more stringent than the state code. Therefore, the state code does not meet the 1992 MEC for one- and two-family dwellings.

Table CO.1. Colorado State Code and the 1992 MEC Envelope Requirements

\begin{tabular}{||l|c|c|}
\hline \hline Component & State Code U-Values & MEC U-Values \\
\hline Ceiling & .05 & $0.032-0.026$ \\
\hline Wall & .20 & $0.14-0.11$ \\
\hline Floor & .08 & 0.05 \\
\hline Slab (R-Value) & $4-5.5$ & $4-5.5$ \\
\hline Basement & None & $0.09-0.10$ \\
\hline
\end{tabular}




\section{Connecticut}

The 1994 Connecticut State Building Code - Connecticut Supplement contains amendments to the 1990 BOCA National Building Code (BOCA 1990a) and BOCA National Mechanical Code (BOCA 1990b). The supplement provides a single set of prescriptive $U$-value thermal envelope requirements that apply to the whole state. An overall envelope U-value comparison was performed.

Table CT.1 shows the average overall envelope U-values for the state code and the $1992 \mathrm{MEC}$ (CABO 1992). The average overall U-value for the state code is higher than the average overall MEC Uvalue. Therefore, the Connecticut code does not meet the 1992 MEC requirements for one- and twofamily dwellings.

Table CT.1. Average Overall Envelope U-Value for Connecticut

\begin{tabular}{||c|c|}
\hline & $\mathrm{U}_{0}$ \\
\hline State Average & 0.101 \\
& $(36 \%$ above MEC average $)$ \\
\hline MEC Average & 0.075 \\
\hline
\end{tabular}

Tables CT.2 and CT.3 show a more detailed comparison of the state code to the 1992 MEC by the type of foundation insulation used and by envelope component. Table CT.2 also shows combined Uvalues, which are the average overall envelope $U$-values based on foundation type, averaged and weighted by the proportion of homes in the state with the given foundation type (percentages shown in parentheses). Table CT.3 shows the state average U-value for walls, ceilings, and floors over unheated spaces and the state average F-value for slab and basement walls.

Table CT.2. Average Overall Envelope U-Values by Foundation Type for Connecticut

\begin{tabular}{||c|c|c|c|c||}
\hline & Slab (2\%) & $\begin{array}{c}\text { Floor Over Unheated } \\
\text { Space (36\%) }\end{array}$ & $\begin{array}{c}\text { Basement } \\
\text { Wall (62\%) }\end{array}$ & Combined \\
\hline State Average & 0.084 & 0.082 & 0.114 & 0.101 \\
\hline MEC Average & 0.082 & 0.071 & 0.076 & 0.075 \\
\hline
\end{tabular}


Table CT.3. Average Envelope Component U-Values or F-Values for Connecticut

\begin{tabular}{|l|c|c|c|c|c||}
\hline & $\begin{array}{c}\text { Ceiling } \\
\left(\mathrm{Btu} / \mathrm{h} \bullet \mathrm{ft}^{2} \bullet^{\circ} \mathrm{F}\right)\end{array}$ & $\begin{array}{c}\mathrm{Wall}^{(\mathrm{a})} \\
\left(\mathrm{Btu} / \mathrm{h} \cdot \mathrm{ft}^{2} \bullet{ }^{\circ} \mathrm{F}\right)\end{array}$ & $\begin{array}{c}\text { Slab } \\
\left(\mathrm{Btu} / \mathrm{h} \bullet \mathrm{ft} \bullet{ }^{\circ} \mathrm{F}\right)\end{array}$ & $\begin{array}{c}\text { Floors } \\
\left(\mathrm{Btu} / \mathrm{h} \bullet \mathrm{ft}^{2} \bullet^{\circ} \mathrm{F}\right)\end{array}$ & $\begin{array}{c}\text { Basement } \\
\left(\mathrm{Btu} / \mathrm{h} \bullet \mathrm{ft}{ }^{\circ} \mathrm{F}\right)\end{array}$ \\
\hline $\begin{array}{l}\text { State } \\
\text { Average }\end{array}$ & 0.030 & 0.125 & 0.804 & 0.080 & 2.584 \\
\hline $\begin{array}{l}\text { MEC } \\
\text { Average }\end{array}$ & 0.026 & 0.125 & 0.783 & 0.050 & 1.227 \\
\hline (a) Includes windows and doors.
\end{tabular}

Table CT.4 and CT.5 show the envelope requirements for the state code and for the 1992 MEC.

Table CT.4. Connecticut State Code Envelope Requirements

\begin{tabular}{||l|c|}
\hline Ceiling U-Value & 0.030 \\
\hline Gross Wall U-Value & 0.125 \\
\hline Floor U-Value & 0.080 \\
\hline Basement Wall R-Value & 0 \\
\hline Basement Depth & - \\
\hline Slab R-Value & 5 \\
\hline Slab Depth & 2 \\
\hline
\end{tabular}


Table CT.5. 1992 MEC Envelope Requirements for Connecticut

\begin{tabular}{|l|c|c|c|c|c|c||}
\hline & $\begin{array}{c}\text { Ceiling } \\
\text { U-Value }\end{array}$ & $\begin{array}{c}\text { Wall } \\
\text { U-Value }\end{array}$ & $\begin{array}{c}\text { Floor } \\
\text { U-Value }\end{array}$ & $\begin{array}{c}\text { Basement } \\
\text { U-Value }\end{array}$ & $\begin{array}{c}\text { Slab } \\
\text { R-Value }\end{array}$ & $\begin{array}{c}\text { Slab } \\
\text { Depth }\end{array}$ \\
\hline Bridgeport & 0.0284 & 0.133 & 0.05 & 0.098 & 4.7 & 2 \\
\hline Danbury & 0.0260 & 0.124 & 0.05 & 0.096 & 5.1 & 4 \\
\hline Enfield & 0.0260 & 0.123 & 0.05 & 0.096 & 5.1 & 4 \\
\hline Groton & 0.0260 & 0.123 & 0.05 & 0.096 & 5.1 & 4 \\
\hline Hartford & 0.0260 & 0.123 & 0.05 & 0.096 & 5.1 & 4 \\
\hline Meriden & 0.0261 & 0.126 & 0.05 & 0.096 & 5.0 & 4 \\
\hline Middletown & 0.0261 & 0.126 & 0.05 & 0.096 & 5.0 & 4 \\
\hline New Haven & 0.0261 & 0.126 & 0.05 & 0.096 & 5.0 & 4 \\
\hline Norwalk & 0.0267 & 0.128 & 0.05 & 0.097 & 4.9 & 2 \\
\hline Storrs & 0.0260 & 0.117 & 0.05 & 0.095 & 5.3 & 4 \\
\hline Waterbury & 0.0261 & 0.126 & 0.05 & 0.096 & 5.0 & 4 \\
\hline
\end{tabular}

Table CT.6 shows the design information and housing starts for each of the cities in the analysis.

Table CT.6. Design Information and Housing Starts for Connecticut

\begin{tabular}{|l|c|c|c||}
\hline & HDD & $\begin{array}{c}\text { Design } \\
\text { Temperature }\end{array}$ & $\begin{array}{c}\text { Housing } \\
\text { Starts }\end{array}$ \\
\hline Bridgeport & 5,501 & 9 & 46 \\
\hline Danbury & 6,103 & -3 & 170 \\
\hline Enfield & 6,156 & 7 & 75 \\
\hline Groton & 6,156 & 7 & 419 \\
\hline Hartford & 6,156 & 7 & 3,144 \\
\hline Meriden & 5,977 & 2 & 37 \\
\hline Middletown & 5,977 & 2 & 531 \\
\hline New Haven & 5,977 & 7 & 1,925 \\
\hline Norwalk & 5,854 & 9 & 1,441 \\
\hline Storrs & 6,522 & -4 & 0 \\
\hline Waterbury & 5,977 & 2 & 536 \\
\hline
\end{tabular}




\section{Delaware}

Delaware has not adopted a state residential energy code. Therefore, Delaware does not meet the 1992 MEC (CABO 1992) requirements for one- and two-family dwellings. 


\section{Florida}

The 1993 Florida Energy Efficiency Code for Building Construction is a mandatory statewide code applicable to all new residential construction. The Florida code divides the state into three regions, a northern region, a central region, and a southern region. Each region has several prescriptive paths that may be used for compliance. The different prescriptive paths are based on the amount of allowed window area. Paths with higher percentages of window area allowances have more stringent envelope requirements. In addition to the prescriptive paths, a performance method may be used to comply. The overall energy calculation used for the performance path is incorporated in compliance software.

One prescriptive path for each region was reviewed based on the assumption that the prescriptive paths within a region resulted in approximately the same energy consumption. The prescriptive path chosen for review was Package $B$ because it most closely represented the package corresponding to the estimated average window area for new homes. An overall $U$-value comparison was made for the state. Door $U$-value requirements are not given in the state code, so a $U$-value of 0.60 was assumed for the analysis. Window requirements in the state code specify either single-pane or double-pane windows. For the comparison, the windows were assumed to be aluminum frame with $U$-values of 1.18 for single pane and 0.72 for double pane.

Table FL. 1 shows the average overall U-values for the state code and the 1992 MEC. The average overall U-value for the state code is lower than the average overall U-value for the MEC. Therefore, the Florida code meets of the 1992 MEC requirements for one- and two-family dwellings.

Table FL.1. Average Overall Envelope U-Values for Regions of Florida

\begin{tabular}{|l|c|c|}
\hline \multicolumn{1}{|c|}{ Region } & $\mathrm{U}_{0}$ & Housing Starts (\%) \\
\hline North & 0.118 & 20 \\
\hline Central & 0.143 & 51 \\
\hline South & 0.143 & 29 \\
\hline State Average & 0.138 & \\
& $(6 \%$ below MEC average $)$ & \\
\hline MEC Average & 0.147 & \\
\hline
\end{tabular}


Tables FL.2 and FL.3 show a more detailed comparison of the state codes to the 1992 MEC by the type of foundation insulation used and by envelope component. Table FL.2 also shows combined Uvalues, which are the average overall envelope U-values based on foundation type, averaged and weighted by the proportion of homes in the state with the given foundation type (percentages shown in parentheses). Table FL.3 shows the state average U-value for walls, ceilings, and floors over unheated spaces and the state average F-value for slab and basement walls.

Table FL.2. Average Overall Envelope U-Values by Foundation Type for Florida

\begin{tabular}{||l|c|c|c|c|}
\hline \multicolumn{1}{|c|}{ Region } & Slab (98\%) & $\begin{array}{c}\text { Floor over Unheated } \\
\text { Space (2\%) }\end{array}$ & $\begin{array}{c}\text { Basement } \\
\text { Wall (0\%) }\end{array}$ & Combined \\
\hline North & 0.118 & 0.098 & 0.134 & 0.118 \\
\hline Central & 0.143 & 0.130 & 0.154 & 0.143 \\
\hline South & 0.143 & 0.130 & 0.154 & 0.143 \\
\hline State Average & 0.138 & 0.123 & 0.150 & 0.138 \\
\hline MEC Average & 0.147 & 0.136 & 0.154 & 0.147 \\
\hline
\end{tabular}

Table FL.3. Average Envelope Component U-Values or F-Values for Florida

\begin{tabular}{||l|c|c|c|c|c|}
\hline \multicolumn{1}{|c|}{ Region } & $\begin{array}{c}\text { Wall } \\
\left(\mathrm{Btu} / \mathrm{h} \bullet \mathrm{ft}^{2} \bullet \circ \mathrm{F}\right)\end{array}$ & $\begin{array}{c}\text { Ceiling } \\
\left(\mathrm{Btu} / \mathrm{h} \bullet \mathrm{ft}^{2} \bullet \circ \mathrm{F}\right)\end{array}$ & $\begin{array}{c}\text { Floor } \\
\left(\mathrm{Btu} / \mathrm{h} \bullet \mathrm{ft}^{2} \bullet \circ \mathrm{F}\right)\end{array}$ & $\begin{array}{c}\text { Slab } \\
(\mathrm{Btu} / \mathrm{h} \bullet \mathrm{ft} \bullet \circ \mathrm{F})\end{array}$ & $\begin{array}{c}\text { Basement } \\
\left(\mathrm{Btu} / \mathrm{h} \bullet \mathrm{ft} \bullet{ }^{\circ} \mathrm{F}\right)\end{array}$ \\
\hline North & 0.189 & 0.035 & 0.047 & 1.042 & 2.584 \\
\hline Central & 0.255 & 0.035 & 0.072 & 1.042 & 2.584 \\
\hline South & 0.255 & 0.035 & 0.072 & 1.042 & 2.584 \\
\hline State Average & 0.242 & 0.035 & 0.067 & 1.042 & 2.584 \\
\hline MEC Average & 0.253 & 0.05 & 0.078 & 1.041 & 2.498 \\
\hline
\end{tabular}

(a) Includes windows and doors.

The results of the duct analysis show duct losses associated with the Florida code requirements to be $4.05 \%$ compared to duct losses of $4.01 \%$ associated with the $1992 \mathrm{MEC}$ requirements.

Table FL. 4 and FL.5 show the envelope requirements for the state code and for the 1992 MEC. 
Table FL.4. Florida State Code Envelope Requirements .

\begin{tabular}{||l|c|c|c|c|c|c|c|c|c||}
\hline \hline Region & $\begin{array}{c}\text { Ceiling } \\
\text { R-Value }\end{array}$ & $\begin{array}{c}\text { Wall } \\
\text { R-Value }\end{array}$ & $\begin{array}{c}\text { Window } \\
\text { U-Value }\end{array}$ & $\begin{array}{c}\text { Door } \\
\text { U-Value }\end{array}$ & $\begin{array}{c}\text { Floor } \\
\text { R-Value }\end{array}$ & $\begin{array}{c}\text { Basement Wall } \\
\text { R-Value }\end{array}$ & $\begin{array}{c}\text { Basement } \\
\text { Depth }\end{array}$ & $\begin{array}{c}\text { Slab } \\
\text { R-Value }\end{array}$ & $\begin{array}{c}\text { Slab } \\
\text { Depth }\end{array}$ \\
\hline North & 30 & 11 & 0.72 & 0.6 & 19 & 0 & - & 0 & - \\
\hline Central & 30 & 11 & 1.18 & 0.6 & 11 & 0 & - & 0 & - \\
\hline South & 30 & 11 & 1.18 & 0.6 & 11 & 0 & - & 0 & - \\
\hline
\end{tabular}

Table FL.5. 1992 MEC Envelope Requirements for Florida

\begin{tabular}{||l|c|c|c|c|c||}
\hline & $\begin{array}{c}\text { Ceiling } \\
\text { U-Value }\end{array}$ & $\begin{array}{c}\text { Wall } \\
\text { U-Value }\end{array}$ & $\begin{array}{c}\text { Floor } \\
\text { U-Value }\end{array}$ & $\begin{array}{c}\text { Slab } \\
\text { R-Value }\end{array}$ & $\begin{array}{c}\text { Basement } \\
\text { U-Value }\end{array}$ \\
\hline Bartow & 0.0500 & 0.255 & 0.08 & 0 & - \\
\hline Belle Glade & 0.0500 & 0.261 & 0.08 & 0 & - \\
\hline Bradenton & 0.0500 & 0.255 & 0.08 & 0 & - \\
\hline Clearwater & 0.0500 & 0.258 & 0.08 & 0 & - \\
\hline Daytona Beach & 0.0500 & 0.244 & 0.08 & 0 & - \\
\hline Deland & 0.0500 & 0.243 & 0.08 & 0 & - \\
\hline Fort Lauderdale & 0.0500 & 0.270 & 0.08 & 0 & - \\
\hline Fort Myers & 0.0500 & 0.262 & 0.08 & 0 & - \\
\hline Fort Pierce & 0.0500 & 0.260 & 0.08 & 0 & - \\
\hline Gainesville & 0.0497 & 0.237 & 0.07 & 0 & - \\
\hline Hialeah & 0.0500 & 0.269 & 0.08 & 0 & - \\
\hline Homestead & 0.0500 & 0.269 & 0.08 & 0 & - \\
\hline Jacksonville & 0.0481 & 0.224 & 0.07 & 0 & - \\
\hline Key West & 0.0500 & 0.275 & 0.08 & 0 & - \\
\hline Lakeland & 0.0500 & 0.255 & 0.08 & 0 & - \\
\hline Melboume & 0.0500 & 0.256 & 0.08 & 0 & - \\
\hline Miami & 0.0500 & 0.272 & 0.08 & 0 & - \\
\hline
\end{tabular}


Table FL.5. (contd)

\begin{tabular}{|l|c|c|c|c|c||}
\hline & $\begin{array}{c}\text { Ceiling } \\
\text { U-Value }\end{array}$ & $\begin{array}{c}\text { Wall } \\
\text { U-Value }\end{array}$ & $\begin{array}{c}\text { Floor } \\
\text { U-Value }\end{array}$ & $\begin{array}{c}\text { Slab } \\
\text { R-Value }\end{array}$ & $\begin{array}{c}\text { Basement } \\
\text { U-Value }\end{array}$ \\
\hline Naples & 0.0500 & 0.267 & 0.08 & 0 & - \\
\hline Ocala & 0.0500 & 0.245 & 0.08 & 0 & - \\
\hline Orlando & 0.0500 & 0.254 & 0.08 & 0 & - \\
\hline Palatka & 0.0500 & 0.243 & 0.08 & 0 & - \\
\hline Pensacola & 0.0473 & 0.217 & 0.07 & 0 & 0.168 \\
\hline Plant City & 0.0500 & 0.255 & 0.08 & 0 & - \\
\hline Pompano Beach & 0.0500 & 0.270 & 0.08 & 0 & - \\
\hline St. Petersburg & 0.0500 & 0.258 & 0.08 & 0 & - \\
\hline Sanford & 0.0500 & 0.251 & 0.08 & 0 & - \\
\hline Sarasota & 0.0500 & 0.255 & 0.08 & 0 & - \\
\hline Tallahassee & 0.0469 & 0.214 & 0.07 & 0 & 0.167 \\
\hline Tampa & 0.0500 & 0.250 & 0.08 & 0 & - \\
\hline Titusville & 0.0500 & 0.252 & 0.08 & 0 & - \\
\hline Vero Beach & 0.0500 & 0.259 & 0.08 & 0 & - \\
\hline West Palm Beach & 0.0500 & 0.270 & 0.08 & 0 & - \\
\hline Winter Haven & 0.0500 & 0.256 & 0.08 & 0 & - \\
\hline & & & & & \\
\hline
\end{tabular}


Table FL.6 shows the design information and housing starts for each of the cities used in the analysis.

Table FL.6. Design Information and Housing Starts for Florida

\begin{tabular}{||l|c|c|c|c||}
\hline \hline & HDD & $\begin{array}{c}\text { Design } \\
\text { Temperature }\end{array}$ & $\begin{array}{c}\text { Housing } \\
\text { Starts }\end{array}$ & Region \\
\hline Bartow & 620 & 41 & 703 & Central \\
\hline Belle Glade & 465 & 44 & 22 & South \\
\hline Bradenton & 616 & 42 & 1,764 & Central \\
\hline Clearwater & 544 & 40 & 97 & Central \\
\hline Daytona Beach & 904 & 35 & 2,459 & Central \\
\hline Deland & 925 & 36 & 0 & Central \\
\hline Fort Lauderdale & 255 & 45 & 9,246 & South \\
\hline Fort Myers & 440 & 44 & 5,501 & South \\
\hline Fort Pierce & 499 & 42 & 1,732 & North \\
\hline Gainesville & 1,069 & 34 & 1,940 & North \\
\hline Hialeah & 284 & 45 & 1,543 & South \\
\hline Homestead & 283 & 45 & 6,884 & South \\
\hline Jacksonville & 1,402 & 32 & 7,998 & North \\
\hline Key West & 114 & 57 & 486 & South \\
\hline Lakeland & 617 & 41 & 2,485 & Central \\
\hline Melbourne & 606 & 39 & 3,267 & Central \\
\hline Miami & 198 & 47 & 603 & South \\
\hline Naples & 323 & 45 & 5,280 & South \\
\hline Ocala & 881 & 34 & 3,238 & Central \\
\hline Orlando & 660 & 38 & 12,111 & Central \\
\hline Palatka & 36 & 838 & North \\
\hline Pensacola & 29 & 6,285 & North \\
\hline
\end{tabular}


Table FL.6. (contd)

\begin{tabular}{||l|c|c|c|c||}
\hline & HDD & $\begin{array}{c}\text { Design } \\
\text { Temperature }\end{array}$ & $\begin{array}{c}\text { Housing } \\
\text { Starts }\end{array}$ & Region \\
\hline Plant City & 618 & 41 & 191 & Central \\
\hline Pompano Beach & 242 & 46 & 158 & South \\
\hline St. Petersburg & 544 & 40 & 3,346 & Central \\
\hline Sanford & 735 & 40 & 2,614 & Central \\
\hline Sarasota & 616 & 42 & 2,542 & Central \\
\hline Tallahassee & 1,651 & 30 & 1,912 & North \\
\hline Tampa & 741 & 40 & 8,325 & Central \\
\hline Titusville & 711 & 39 & 168 & Central \\
\hline Vero Beach & 523 & 41 & 852 & Central \\
\hline West Palm Beach & 262 & 45 & 9,007 & Central \\
\hline Winter Haven & 612 & 41 & 39 & Central \\
\hline \hline
\end{tabular}




\section{Georgia}

The Georgia State Energy Code for Buildings - 1992 Edition is mandatory for all new residential construction in the state. The Georgia code references the 1992 MEC (CABO 1992) with amendments to include climatic data and thermal performance requirements for major cities. There are no amendments that alter the stringency of the code; therefore, the Georgia code meets the 1992 MEC requirements for oneand two-family dwellings. 


\section{Hawaii}

The Hawaii Model Energy Code is the recommended energy code for new residential construction for Hawaii. As of August 1994, the code had not been adopted by any of the four counties. Because Hawaii is a cooling-dominated state, many of the requirements of the Hawaii code focus on reducing heat gain such as tinting for windows and overhang requirements. An energy comparison was performed using the Automated Residential Energy Standard (ARES) program ${ }^{(2)}$ (Lortz and Taylor 1989). A home built to the state code was compared with a home built to the 1992 MEC (CABO 1992). The home built to the state code unambiguously used less energy than the home built to the MEC. Therefore, the Hawaii code meets 1992 MEC requirements for one- and two-family dwellings. However, the code is not currently mandatory.

(a) The ARES energy simulation is a parameterization of a large database of DOE-2 simulations, allowing the simulation to estimate the energy use given a set of thermal envelope requirements. 


\section{Idaho}

The Idaho Residential Energy Standards is the mandatory statewide energy code for all new residential construction. The Idaho code consists of a single set of prescriptive R-value requirements that apply to the whole state. Door U-value requirements are not given in the state code, so a U-value of 0.60 was assumed for the analysis. Perimeter slab insulation depth requirements and basement wall insulation depth requirements are not specified in the code, so depths of $2 \mathrm{ft}$ for slabs and $8 \mathrm{ft}$ for basements were assumed. An overall U-value analysis was performed.

Table ID. 1 shows the average overall envelope U-values for the state code and the 1992 MEC (CABO 1992). The average overall state code U-value is higher than the average overall MEC U-value. Therefore, the Idaho code does not meet the 1992 MEC requirements for one- and two-family dwellings.

Table ID.1. Average Overall Envelope U-Value for Idaho

\begin{tabular}{||c|c|}
\hline & $U_{o}$ \\
\hline State Average & 0.081 \\
& $(14 \%$ above MEC average $)$ \\
\hline MEC Average & 0.071 \\
\hline
\end{tabular}

Tables ID.2 and ID.3 show a more detailed comparison of the state code to the 1992 MEC by the type of foundation insulation used and by envelope component. Table ID. 2 also shows combined U-values, which are the average overall envelope $U$-values based on foundation type, averaged and weighted by the proportion of homes in the state with the given foundation type (percentages shown in parentheses).

Table ID. 3 shows the state average U-value for walls, ceilings, and floors over unheated spaces and the state average F-value for slab and basement walls.

Table ID.2. Average Overall Envelope U-Values by Foundation Type for Idaho

\begin{tabular}{||l|c|c|c|c||}
\hline & Slab (3\%) & $\begin{array}{c}\text { Floor Over Unheated } \\
\text { Space (84\%) }\end{array}$ & $\begin{array}{c}\text { Basement } \\
\text { Wall (13\%) }\end{array}$ & Combined \\
\hline State Average & 0.092 & 0.081 & 0.083 & 0.081 \\
\hline MEC Average & 0.081 & 0.070 & 0.076 & 0.071 \\
\hline
\end{tabular}


Table ID.3. Average Envelope Component U-Values or F-Values for Idaho

\begin{tabular}{|l|c|c|c|c|c||}
\hline & $\begin{array}{c}\text { Ceiling } \\
\left(\mathrm{Btu} / \mathrm{h} \bullet \mathrm{ft}^{2} \bullet \circ \mathrm{F}\right)\end{array}$ & $\begin{array}{c}\mathrm{Wall}^{\text {(a) }} \\
\left(\mathrm{Btu} / \mathrm{h} \bullet \mathrm{ft}^{2} \bullet{ }^{\circ} \mathrm{F}\right)\end{array}$ & $\begin{array}{c}\text { Slab } \\
\left(\mathrm{Btu} / \mathrm{h} \bullet \mathrm{ft} \bullet{ }^{\circ} \mathrm{F}\right)\end{array}$ & $\begin{array}{c}\text { Floor } \\
\left(\mathrm{Btu} / \mathrm{h} \bullet \mathrm{ft}^{2} \bullet{ }^{\circ} \mathrm{F}\right)\end{array}$ & $\begin{array}{c}\text { Basement } \\
\left(\mathrm{Btu} / \mathrm{h} \bullet \mathrm{ft} \bullet{ }^{\circ} \mathrm{F}\right)\end{array}$ \\
\hline State Average & 0.030 & 0.149 & 0.767 & 0.047 & 1.182 \\
\hline MEC Average & 0.027 & 0.122 & 0.781 & 0.050 & 1.223 \\
\hline (a) Includes windows and doors. & \\
\hline
\end{tabular}

Table ID.4 and ID.5 show the envelope requirements for the state code and for the 1992 MEC.

Table ID.4. Idaho State Code Envelope Requirements

\begin{tabular}{||l|c|}
\hline Ceiling R-Value & 38 \\
\hline Wall R-Value & 19 \\
\hline Window U-Value & 0.65 \\
\hline Door U-Value & 0.36 \\
\hline Floor R-Value & 19 \\
\hline Basement Wall R-Value & 10 \\
\hline Basement Depth & 8 \\
\hline Slab R-Value & 10 \\
\hline Slab Depth & 2 \\
\hline
\end{tabular}


Table ID.5. 1992 MEC Envelope Requirements for Idaho

\begin{tabular}{|l|c|c|c|c|c|c||}
\hline & $\begin{array}{c}\text { Ceiling } \\
\text { U-Value }\end{array}$ & $\begin{array}{c}\text { Wall } \\
\text { U-Value }\end{array}$ & $\begin{array}{c}\text { Floor } \\
\text { U-Value }\end{array}$ & $\begin{array}{c}\text { Basement } \\
\text { U-Value }\end{array}$ & $\begin{array}{c}\text { Slab } \\
\text { R-Value }\end{array}$ & $\begin{array}{c}\text { Slab } \\
\text { Depth }\end{array}$ \\
\hline Boise & 0.0269 & 0.129 & 0.05 & 0.097 & 4.9 & 2 \\
\hline Caldwell & 0.0279 & 0.132 & 0.05 & 0.097 & 4.7 & 2 \\
\hline Coeur d'Alene & 0.0260 & 0.118 & 0.05 & 0.095 & 5.3 & 4 \\
\hline Idaho Falls & 0.0260 & 0.110 & 0.05 & 0.091 & 6.3 & 4 \\
\hline Moscow & 0.0260 & 0.115 & 0.05 & 0.095 & 5.5 & 4 \\
\hline Pocatello & 0.0260 & 0.110 & 0.05 & 0.093 & 5.8 & 4 \\
\hline
\end{tabular}

Table ID.6 shows the design information and housing starts for each of the cities used in the analysis.

Table ID.6. Design Information and Housing Starts for Idaho

\begin{tabular}{||l|c|c|c||}
\hline & HDD & $\begin{array}{c}\text { Design } \\
\text { Temperature }\end{array}$ & $\begin{array}{c}\text { Housing } \\
\text { Starts }\end{array}$ \\
\hline Boise & 5,808 & 10 & 4,236 \\
\hline Caldwell & 5,597 & 5 & 1,082 \\
\hline Coeur d'Alene & 6,462 & -1 & 1,562 \\
\hline Idaho Falls & 7,998 & -6 & 1,288 \\
\hline Moscow & 6,691 & 0 & 469 \\
\hline Pocatello & 7,131 & -1 & 964 \\
\hline
\end{tabular}




\section{Illinois}

Illinois has not adopted a state residential energy code. Therefore, Illinois does not meet the 1992 MEC (CABO 1992) requirements for one- and two-family. 


\section{Indiana}

The Indiana Energy Conservation Code, 1992 Edition is the mandatory state energy code for Indiana. The Indiana code references the 1992 MEC (CABO 1992) with amendments. The code subdivides the state into three regions; a northern, a central, and a southern region. Each region has its own envelope Uvalue requirements. An overall $U$-value comparison was performed to verify that the amendments did not reduce the stringency of the $\mathrm{MEC}$.

Table IN. 1 shows the average overall U-values for the state code and the 1992 MEC. The average overall U-value for the state code is lower than the average overall U-value for the MEC. Because it is within 5\% of the overall MEC U-value, the Indiana code has been classified as marginally meeting the 1992 MEC for one- and two-family dwellings.

Table IN.1. Average Overall Envelope U-Values for Regions of Indiana

\begin{tabular}{||l|c|c||}
\hline \multicolumn{1}{|c|}{ Region } & $\mathrm{U}_{\mathrm{o}}$ & Housing Starts (\%) \\
\hline North & 0.072 & 35 \\
\hline Central & 0.077 & 43 \\
\hline South & 0.082 & 23 \\
\hline State Average & 0.076 & \\
& $(1 \%$ below MEC average $)$ & \\
\hline MEC Average & 0.077 & \\
\hline
\end{tabular}

Tables IN.2 and IN.3 show a more detailed comparison of the state code to the 1992 MEC by the type of foundation insulation used and by envelope component. Table IN.2 also shows combined U-values, which are the average overall envelope $U$-values based on foundation type, averaged and weighted by the proportion of homes in the state with the given foundation type (percentages shown in parentheses). Table IN.3 shows the state average U-value for walls, ceilings, and floors over unheated spaces and the state average F-value for slab and basement walls. 
Table IN.2. Average Overall Envelope U-Values by Foundation Type for Indiana

\begin{tabular}{||l|c|c|c|c||}
\hline \multicolumn{1}{|c|}{ Region } & Slab (36\%) & $\begin{array}{c}\text { Floor over Unheated } \\
\text { Space (60\%) }\end{array}$ & $\begin{array}{c}\text { Basement } \\
\text { Wall (4\%) }\end{array}$ & Combined \\
\hline North & 0.078 & 0.069 & 0.075 & 0.072 \\
\hline Central & 0.082 & 0.073 & 0.078 & 0.077 \\
\hline South & 0.087 & 0.078 & 0.082 & 0.082 \\
\hline State Average & 0.081 & 0.073 & 0.078 & 0.076 \\
\hline MEC Average & 0.084 & 0.073 & 0.078 & 0.077 \\
\hline
\end{tabular}

Table IN.3. Average Envelope Component U-Values or F-Values for Indiana

\begin{tabular}{||l|c|c|c|c|c||}
\hline \multicolumn{1}{|c|}{ Region } & $\begin{array}{c}\text { Wall } \\
\left(\mathrm{Btu} / \mathrm{h} \bullet \mathrm{ft}^{2} \bullet \circ \mathrm{F}\right)\end{array}$ & $\begin{array}{c}\text { Ceiling } \\
\left(\mathrm{Btu} / \mathrm{h} \bullet \mathrm{ft}^{2} \bullet{ }^{\circ} \mathrm{F}\right)\end{array}$ & $\begin{array}{c}\text { Floor } \\
\left(\mathrm{Btu} / \mathrm{h} \bullet \mathrm{ft}^{2} \bullet{ }^{\circ} \mathrm{F}\right)\end{array}$ & $\begin{array}{c}\text { Slab } \\
\left(\mathrm{Btu} / \mathrm{h} \bullet \mathrm{ft} \bullet{ }^{\circ} \mathrm{F}\right)\end{array}$ & $\begin{array}{c}\text { Basement } \\
\left(\mathrm{Btu} / \mathrm{h} \bullet \mathrm{ft} \bullet{ }^{\circ} \mathrm{F}\right)\end{array}$ \\
\hline North & 0.120 & 0.026 & 0.05 & 0.708 & 1.221 \\
\hline Central & 0.130 & 0.027 & 0.05 & 0.708 & 1.230 \\
\hline South & 0.140 & 0.031 & 0.05 & 0.708 & 1.239 \\
\hline State Average & 0.129 & 0.028 & 0.05 & 0.708 & 1.229 \\
\hline MEC Average & 0.129. & 0.028 & 0.05 & 0.780 & 1.231 \\
\hline (a) Includes walls and windows. & & & \\
\hline
\end{tabular}

The results of the duct analysis showed duct losses associated with the Indiana code requirements to be $4.0 \%$ compared to duct losses $3.0 \%$ associated with the $1992 \mathrm{MEC}$ requirements.

Tables IN.4 and IN.5 show the envelope requirements for the state code and for the 1992 MEC. 
Table IN.4. Indiana State Code Envelope Requirements

\begin{tabular}{||l|c|c|c|c|c|c|c||}
\hline Region & $\begin{array}{c}\text { Ceiling } \\
\text { U-Value }\end{array}$ & $\begin{array}{c}\text { Wall } \\
\text { U-Value }\end{array}$ & $\begin{array}{c}\text { Floor } \\
\text { U-Value }\end{array}$ & $\begin{array}{c}\text { Basement Wall } \\
\text { R-Value }\end{array}$ & $\begin{array}{c}\text { Basement } \\
\text { Depth }\end{array}$ & $\begin{array}{c}\text { Slab } \\
\text { R-Value }\end{array}$ & $\begin{array}{c}\text { Slab } \\
\text { Depth }\end{array}$ \\
\hline North & 0.026 & 0.12 & 0.05 & 8.8 & 8 & 7.5 & 4 \\
\hline Central & 0.027 & 0.13 & 0.05 & 8.6 & 8 & 7.5 & 4 \\
\hline South & 0.031 & 0.14 & 0.05 & 8.4 & 8 & 7.5 & 4 \\
\hline
\end{tabular}

Table IN.5. 1992 MEC Envelope Requirements for Indiana

\begin{tabular}{|l|c|c|c|c|c|c||}
\hline & $\begin{array}{c}\text { Ceiling } \\
\text { U-Value }\end{array}$ & $\begin{array}{c}\text { Wall } \\
\text { U-Value }\end{array}$ & $\begin{array}{c}\text { Floor } \\
\text { U-Value }\end{array}$ & $\begin{array}{c}\text { Basement } \\
\text { U-Value }\end{array}$ & $\begin{array}{c}\text { Slab } \\
\text { R-Value }\end{array}$ & Slab Depth \\
\hline Anderson & 0.0265 & 0.127 & 0.05 & 0.097 & 4.9 & 2 \\
\hline Bloomington & 0.0283 & 0.133 & 0.05 & 0.098 & 4.7 & 3 \\
\hline Columbus & 0.0283 & 0.133 & 0.05 & 0.098 & 4.7 & 3 \\
\hline Crawfordsville & 0.0260 & 0.126 & 0.05 & 0.096 & 5.0 & 4 \\
\hline Elwood & 0.0260 & 0.122 & 0.05 & 0.096 & 5.2 & 4 \\
\hline Evansville & 0.0343 & 0.153 & 0.05 & 0.106 & 4.0 & 2 \\
\hline Fort Wayne & 0.0260 & 0.121 & 0.05 & 0.095 & 5.2 & 4 \\
\hline Frankfort & 0.0260 & 0.124 & 0.05 & 0.096 & 5.1 & 4 \\
\hline Gary & 0.0260 & 0.122 & 0.05 & 0.096 & 5.2 & 4 \\
\hline Goshen & 0.0260 & 0.121 & 0.05 & 0.096 & 5.2 & 4 \\
\hline Greenfield & 0.0270 & 0.129 & 0.05 & 0.097 & 4.9 & 2 \\
\hline Hobart & 0.0260 & 0.125 & 0.05 & 0.096 & 5.0 & 4 \\
\hline Huntington & 0.0261 & 0.126 & 0.05 & 0.096 & 5.0 & 4 \\
\hline Indianapolis & 0.0277 & 0.131 & 0.05 & 0.097 & 4.8 & 2 \\
\hline Kokomo & 0.0260 & 0.125 & 0.05 & 0.096 & 5.0 & 4 \\
\hline La Porte & 0.0260 & 0.122 & 0.05 & 0.096 & 5.1 & 4 \\
\hline Lafayette & 0.0260 & 0.121 & 0.05 & 0.096 & 5.2 & 4 \\
\hline
\end{tabular}


Table IN.5. (contd)

\begin{tabular}{||l|c|c|c|c|c|c||}
\hline & $\begin{array}{c}\text { Ceiling } \\
\text { U-Value }\end{array}$ & $\begin{array}{c}\text { Wall } \\
\text { U-Value }\end{array}$ & $\begin{array}{c}\text { Floor } \\
\text { U-Value }\end{array}$ & $\begin{array}{c}\text { Basement } \\
\text { U-Value }\end{array}$ & $\begin{array}{c}\text { Slab } \\
\text { R-Value }\end{array}$ & Slab Depth \\
\hline Marion & 0.0260 & 0.121 & 0.05 & 0.095 & 5.2 & 4 \\
\hline Martinsville & 0.0277 & 0.131 & 0.05 & 0.097 & 4.8 & 2 \\
\hline Muncie & 0.0265 & 0.127 & 0.05 & 0.097 & 4.9 & 2 \\
\hline New Castle & 0.0260 & 0.123 & 0.05 & 0.096 & 5.1 & 4 \\
\hline Richmond & 0.0261 & 0.126 & 0.05 & 0.096 & 5.0 & 4 \\
\hline Seymour & 0.0287 & 0.134 & 0.05 & 0.098 & 4.6 & 2 \\
\hline Shelbyville & 0.0276 & 0.131 & 0.05 & 0.097 & 4.8 & 2 \\
\hline South Bend & 0.0260 & 0.120 & 0.05 & 0.095 & 5.3 & 4 \\
\hline Terre Haute & 0.0283 & 0.133 & 0.05 & 0.097 & 4.7 & 2 \\
\hline Valparaiso & 0.0260 & 0.121 & 0.05 & 0.096 & 5.2 & 4 \\
\hline Vincennes & 0.0300 & 0.139 & 0.05 & 0.098 & 4.4 & 2 \\
\hline Wabash & 0.0260 & 0.118 & 0.05 & 0.095 & 5.3 & 4 \\
\hline West Lafayette & 0.0260 & 0.122 & 0.05 & 0.096 & 5.2 & 4 \\
\hline \hline
\end{tabular}

Table IN.6 shows the design information and housing starts for each of the cities used in the analysis.

Table IN.6. Design Information and Housing Starts for Indiana

\begin{tabular}{|l|c|c|c|c||}
\hline & HDD & $\begin{array}{c}\text { Design } \\
\text { Temperature }\end{array}$ & Housing Starts & Region \\
\hline Anderson & 5,891 & 6 & 343 & Central \\
\hline Bloomington & 5,516 & 5 & 1,440 & South \\
\hline Columbus & 5,516 & 7 & 494 & South \\
\hline Crawfordsville & 5,998 & 3 & 389 & Central \\
\hline Elwood & 6,244 & 4 & 0 & Central \\
\hline Evansville & 4,262 & 9 & 2,383 & South \\
\hline
\end{tabular}


Table IN.6. (contd)

\begin{tabular}{||l|c|c|c|c||}
\hline & HDD & $\begin{array}{c}\text { Design } \\
\text { Temperature }\end{array}$ & Housing Starts & Region \\
\hline Fort Wayne & 6,324 & 1 & 2,319 & North \\
\hline Frankfort & 6,129 & 2 & 0 & Central \\
\hline Gary & 6,256 & 5 & 2,036 & North \\
\hline Goshen & 6,294 & 1 & 1,942 & North \\
\hline Greenfield & 5,800 & 6 & 550 & Central \\
\hline Hobart & 6,030 & 2 & 37 & Central \\
\hline Huntington & 5,987 & 1 & 306 & North \\
\hline Indianapolis & 5,653 & 2 & 7,536 & Central \\
\hline Kokomo & 6,042 & 0 & 338 & Central \\
\hline La Porte & 6,229 & 3 & 494 & North \\
\hline Lafayette & 6,304 & 3 & 1,099 & Central \\
\hline Marion & 6,320 & 0 & 179 & Central \\
\hline Martinsville & 5,641 & 14 & 1,769 & Central \\
\hline Muncie & 5,891 & 2 & 479 & Central \\
\hline New Castle & 6,141 & 4 & 178 & Central \\
\hline Richmond & 5,979 & 2 & 251 & Central \\
\hline Seymour & 5,438 & 6 & 1,666 & South \\
\hline Shelbyville & 5,666 & 3 & 285 & Central \\
\hline South Bend & 6,381 & 1 & 1,776 & North \\
\hline Terre Haute & 5,527 & 4 & 416 & South \\
\hline Valparaiso & 6,295 & 3 & 1,656 & North \\
\hline Vincennes & 5,163 & 6 & 59 & South \\
\hline Wabash & 6,481 & 4 & 0 & North \\
\hline West Lafayette & 6,229 & 3 & 172 & Central \\
\hline \hline
\end{tabular}


This analysis did not include a review of homes insulated with crawl space wall insulation because this type of insulation is found in a small percentage of new residential construction nationally. It is worth noting, however, that crawl space wall insulation requirements for the Indiana state code are significantly less stringent than the $1992 \mathrm{MEC}$ requirements. The state code requires a U-value of 0.10 whereas the MEC requires a more stringent $U$-value of 0.06 . 


\section{Iowa}

The Iowa State Building Code is the state building code. The energy portion of the code applies to all new construction and references the 1992 MEC (CABO 1992) with amendments to include climatic data and thermal performance requirements for major cities. Amendments to the code significantly alter the state code's duct insulation requirements. The duct insulation requirements associated with the state code result in $12 \%$ duct losses compared to $3 \%$ duct losses associated with the $1992 \mathrm{MEC}$ requirements. Although the Iowa code adopts the 1992 MEC for its envelope requirements, the difference in duct insulation requirements was considered significant enough to classify the lowa code as not meeting the 1992 MEC requirements for one- and two-family dwellings. 


\section{Kansas}

The thermal performance requirements of the Kansas Corporation Commission Thermal Treatment Standards are given in terms of an overall heat loss value of $35 \mathrm{Btu} / \mathrm{h} \bullet \mathrm{ft}^{2}$ for floors for all electrically heated dwellings based on a design temperature differential of $80^{\circ} \mathrm{F}$. An approximate overall envelope Uvalue may be computed by assuming an insulated floor. Infiltration is assumed to be the same for homes built to the Kansas state code and to the MEC. The equation used for calculating an envelope U-value is

$$
\text { Heat Loss }=\mathrm{U}_{\mathrm{o}} \cdot \mathrm{A}_{\mathrm{env}} \cdot \delta \mathrm{T}
$$

where $U_{0}=$ overall heat transmission of a gross area of the exterior building envelope

$\mathrm{A}_{\mathrm{env}}=$ gross area of exterior building envelope

$\delta \mathrm{T}=$ design temperature differential.

Solving Equation (A.1) for the overall U-value in terms of heat loss per square foot of floor space gives

$$
\mathrm{U}_{\mathrm{o}}=\frac{\left(\text { Heat Loss } / \mathrm{A}_{\mathrm{fl}}\right)}{(\delta \mathrm{T})\left(1+\mathrm{A}_{\text {ceil }} / \mathrm{A}_{\mathrm{n}}+\mathrm{A}_{\text {gross wall }} / \mathrm{A}_{\mathrm{n}}\right)}
$$

where $A_{f 1}=$ gross floor area

$A_{\text {ceil }}=$ gross ceiling area

$A_{\text {gross wall }}=$ gross wall area.

Using the prototype dimensions described in Section 2.5.1 of this report, the average overall U-value is 0.14. The $1992 \mathrm{MEC}$ average overall U-value is 0.081 . Because the MEC average overall U-value is significantly lower than the calculated U-value, the Kansas Corporation Commission's standard for electrically heated buildings does not meet the 1992 MEC requirements for one- and two-family dwellings. 


\section{Kentucky}

Kentucky has adopted the 1990 BOCA National Building Code (BOCA 1990a), which allows compliance using ANSI/ASHRAE/IES Standard 90A-1980 (ASHRAE 1980) or the 1989 MEC (CABO 1989). ANSI/ASHRAE/IES Standard $90 A-1980$ is substantially less stringent than the 1992 MEC (CABO 1992) (see Section 2.3 of this report). Kentucky is updating its code to the 1993 BOCA National Building Code (BOCA 1993). However, the 1993 BOCA National Building Code also allows compliance using ANSI/ASHRAE/IES Standard 90A-1980. Therefore, the Kentucky code does not meet the 1992 MEC requirements for one- and two-family dwellings. 


\section{Louisiana}

Louisiana has not adopted a state residential energy code. Therefore, Louisiana does not meet the 1992 MEC (CABO 1992) requirements for one- and two-family dwellings. 


\section{Maine}

The Maine Energy Efficiency Building Performance Standards Act is the state energy code for new residential construction. The Maine code is mandatory for speculatively built homes, which accounts for about $5 \%$ of the new single-family homes. The other $95 \%$ of homes, which are contracted by the homeowner, are exempt from these requirements.

The code has a single set of prescriptive $\mathrm{R}$-value thermal envelope requirements for walls, ceilings, floors, slabs, and windows. Door U-value requirements are not given in the state code, so a U-value of 0.60 was assumed for the analysis. Basement wall insulation is required on basement walls down to the frost line. The frost line depth is established in the code based on three regions in the state. An overall envelope U-value comparison was performed.

Table ME.1 shows the overall envelope U-value for the state code and the 1992 MEC (CABO 1992). The average overall $U$-value for the state is higher than the average overall MEC U-value. Therefore, the Maine code does not meet the 1992 MEC requirements for one- and two-family dwellings.

Table ME.1. Average Overall Envelope U-Values for Regions of Maine

\begin{tabular}{|c|c|c|}
\hline Region & $\mathrm{U}_{\mathrm{o}}$ & Housing Starts (\%) \\
\hline 1 & 0.085 & 89 \\
\hline 2 & 0.082 & 8 \\
\hline 3 & 0.080 & 3 \\
\hline State Average & $\begin{array}{c}0.085 \\
(20 \% \text { above MEC average })\end{array}$ \\
\hline MEC Average & 0.070 & \\
\hline
\end{tabular}

Tables ME. 2 and ME. 3 show a more detailed comparison of the state code to the 1992 MEC by the type of foundation insulation used and by envelope component. Table ME. 2 also shows combined Uvalues, which are the average overall envelope $U$-values based on foundation type, averaged together and weighted by the proportion of homes in the state with the given foundation type (percentages shown in parentheses). Table ME.3 shows the state average U-value for walls, ceilings, and floors over unheated spaces and the state average F-value for slab and basement walls. 
Table ME.2. Average Overall Envelope U-Values by Foundation Type for Maine

\begin{tabular}{|c|c|c|c|c|}
\hline Region & Slab (4\%) & $\begin{array}{c}\text { Floor over Unheated } \\
\text { Space (23\%) }\end{array}$ & $\begin{array}{c}\text { Basement } \\
\text { Wall (73\%) }\end{array}$ & Combined \\
\hline 1 & 0.087 & 0.075 & 0.088 & 0.085 \\
\hline 2 & 0.087 & 0.075 & 0.084 & 0.082 \\
\hline 3 & 0.087 & 0.075 & 0.081 & 0.080 \\
\hline State Average & 0.087 & 0.075 & 0.087 & 0.085 \\
\hline MEC Average & 0.077 & 0.065 & 0.071 & 0.070 \\
\hline
\end{tabular}

Table ME.3. Average Envelope Component U-Values or F-Values for Maine

\begin{tabular}{|c|c|c|c|c|c||}
\hline Region & $\begin{array}{c}\text { Wall } \\
\left(\mathrm{Btu} / \mathrm{h} \cdot \mathrm{ft}^{2} \bullet{ }^{\circ} \mathrm{F}\right)\end{array}$ & $\begin{array}{c}\text { Ceiling } \\
\left(\mathrm{Btu} / \mathrm{h} \bullet \mathrm{ft}^{2} \bullet \circ \mathrm{F}\right)\end{array}$ & $\begin{array}{c}\text { Floor } \\
\left(\mathrm{Btu} / \mathrm{h} \bullet \mathrm{ft}^{2} \bullet{ }^{\circ} \mathrm{F}\right)\end{array}$ & $\begin{array}{c}\text { Slab } \\
\left(\mathrm{Btu} / \mathrm{h} \bullet \mathrm{ft} \bullet{ }^{\circ} \mathrm{F}\right)\end{array}$ & $\begin{array}{c}\text { Basement } \\
(\mathrm{Btu} / \mathrm{h} \bullet \mathrm{ft} \bullet \circ \mathrm{F})\end{array}$ \\
\hline 1 & 0.135 & 0.030 & 0.047 & 0.767 & 1.510 \\
\hline 2 & 0.135 & 0.030 & 0.047 & 0.767 & 1.359 \\
\hline 3 & 0.135 & 0.030 & 0.047 & 0.767 & 1.253 \\
\hline State Average & 0.135 & 0.030 & 0.047 & 0.767 & 1.490 \\
\hline MEC Average & 0.110 & 0.026 & 0.050 & 0.795 & 1.206 \\
\hline (a) Includes windows and doors. & & & \\
\hline
\end{tabular}

Tables ME.4 and ME.5 show the envelope requirements for the state code and for the 1992 MEC. 
Table ME.4. Maine State Code Envelope Requirements

\begin{tabular}{|c|c|c|c|c|c|c|c|c|c||}
\hline Region & $\begin{array}{c}\text { Ceiling } \\
\text { R-Value }\end{array}$ & $\begin{array}{c}\text { Wall } \\
\text { R-Value }\end{array}$ & $\begin{array}{c}\text { Window } \\
\text { U-Value }\end{array}$ & $\begin{array}{c}\text { Door } \\
\text { U-Value }\end{array}$ & $\begin{array}{c}\text { Floor } \\
\text { R-Value }\end{array}$ & $\begin{array}{c}\text { Basement Wall } \\
\text { R-Value }\end{array}$ & $\begin{array}{c}\text { Basement } \\
\text { Depth }\end{array}$ & $\begin{array}{c}\text { Slab } \\
\text { R-Value }\end{array}$ & $\begin{array}{c}\text { Slab } \\
\text { Depth }\end{array}$ \\
\hline 1 & 38 & 19 & 0.5 & 0.6 & 19 & 10 & 4 & 10 & 2 \\
\hline 2 & 38 & 19 & 0.5 & 0.6 & 19 & 10 & 5 & 10 & 2 \\
\hline 3 & 38 & 19 & 0.5 & 0.6 & 19 & 10 & 6 & 10 & 2 \\
\hline
\end{tabular}

Table ME.5. 1992 MEC Envelope Requirements for Maine

\begin{tabular}{|l|c|c|c|c|c|c||}
\hline & $\begin{array}{c}\text { Ceiling } \\
\text { U-Value }\end{array}$ & $\begin{array}{c}\text { Wall } \\
\text { U-Value }\end{array}$ & $\begin{array}{c}\text { Floor } \\
\text { U-Value }\end{array}$ & $\begin{array}{c}\text { Basement } \\
\text { U-Value }\end{array}$ & $\begin{array}{c}\text { Slab } \\
\text { R-Value }\end{array}$ & $\begin{array}{c}\text { Slab } \\
\text { Depth }\end{array}$ \\
\hline Augusta & 0.026 & 0.11 & 0.05 & 0.092 & 6.1 & 4 \\
\hline Bangor & 0.026 & 0.11 & 0.05 & 0.091 & 6.3 & 4 \\
\hline Lewiston & 0.026 & 0.11 & 0.05 & 0.093 & 5.9 & 4 \\
\hline Portland & 0.026 & 0.11 & 0.05 & 0.093 & 6.0 & 4 \\
\hline Presque Isle & 0.026 & 0.11 & 0.05 & 0.060 & 7.2 & 4 \\
\hline Waterville & 0.026 & 0.11 & 0.05 & 0.093 & 6.0 & 4 \\
\hline
\end{tabular}

Table ME.6 shows the design information and housing starts for each of the cities used in the analysis.

Table ME.6. Design Information and Housing Starts for Maine

\begin{tabular}{|l|c|c|c|c||}
\hline & HDD & $\begin{array}{c}\text { Design } \\
\text { Temperature }\end{array}$ & $\begin{array}{c}\text { Housing } \\
\text { Starts }\end{array}$ & Region \\
\hline Augusta & 7,598 & -3 & 357 & 1 \\
\hline Bangor & 7,951 & -6 & 322 & 2 \\
\hline Lewiston & 7,351 & -2 & 394 & 1 \\
\hline Portland & 7,502 & -1 & 2678 & 1 \\
\hline Presque Isle & 9,242 & -19 & 117 & 3 \\
\hline Waterville & 7,514 & -4 & 74 & 1 \\
\hline
\end{tabular}




\section{Maryland}

The Code of Maryland Regulations Title 05 is the mandatory building code for new residential construction. The Maryland code adopts the 1993 BOCA National Building Code (BOCA 1993) by reference, which allows compliance by using ANSI/ASHRAEIIES Standard 90A-1980 (ASHRAE 1980) or the 1992 MEC (CABO 1992). ANSIIASHRAE/IES Standard 90A-1980 is significantly less stringent than the 1992 MEC (see Section 2.3 of this report). Therefore, Maryland does not meet the 1992 MEC requirements for one- and two-family dwellings. 


\section{Massachusetts}

The Massachusetts State Building Code, Fifth Edition is the mandatory state building code for new buildings. The energy portion of the Massachusetts code gives separate U-value requirements for electric and nonelectric homes. An overall U-value comparison was performed for both categories. The U-value requirements in the state code do not include framing. For the analysis, these U-values were adjusted to include framing using the U-value calculation method described in the 1993 ASHRAE Handbook Fundamentals (ASHRAE 1993).

Table MA. 1 shows the average overall envelope U-values for the state code and the $1992 \mathrm{MEC}$ (CABO 1992) for electric and nonelectric homes. The average overall U-value for the state nonelectric code is higher than the average overall MEC U-value. Therefore, the Massachusetts nonelectric code does not meet the 1992 MEC requirements for one- and two-family dwellings. The average overall Uvalue for the state electric code is lower than the average overall MEC U-value. Because it is within 5\% of the overall MEC U-value, the Massachusetts electric code has been classified as marginally meeting the 1992 MEC for one--and two-family dwellings.

Table MA.1. Average Overall Envelope U-Values for Massachusetts

\begin{tabular}{||l|c|}
\hline & $\mathrm{U}_{0}$ \\
\hline State Average (Nonelectric) & $\begin{array}{c}0.092 \\
(24 \% \text { above MEC average })\end{array}$ \\
\hline State Average (Electric) & $\begin{array}{c}0.072 \\
(2 \% \text { below MEC average) }\end{array}$ \\
\hline MEC Average & 0.074 \\
\hline
\end{tabular}

Tables MA. 2 and MA.3 show a more detailed comparison of the state code to the 1992 MEC by the type of foundation insulation used and by envelope component. Table MA.2 also shows combined Uvalues, which are the average overall envelope $U$-values based on foundation type, averaged and weighted by the proportion of homes in the state with the given foundation type (percentages shown in parentheses). Table MA.3 shows the state average U-value for walls, ceilings, and floors over unheated spaces and the state average F-value for slab and basement walls. 
Table MA.2. Average Overall Envelope U-Values by Foundation Type for Massachusetts

\begin{tabular}{||l|c|c|c|c||}
\hline & Slab (2\%) & $\begin{array}{c}\text { Floor Over Unheated } \\
\text { Space (48\%) }\end{array}$ & $\begin{array}{c}\text { Basement } \\
\text { Wall (50\%) }\end{array}$ & Combined \\
\hline State Average (Nonelectric) & 0.102 & 0.093 & 0.090 & 0.092 \\
\hline State Average (Electric) & 0.081 & 0.072 & 0.073 & 0.072 \\
\hline MEC Average & 0.082 & 0.071 & 0.077 & 0.074 \\
\hline
\end{tabular}

Table MA.3. Average Envelope Component U-Values or F-Values for Massachusetts

\begin{tabular}{|l|c|c|c|c|c||}
\hline & $\begin{array}{c}\text { Ceiling } \\
\left(\mathrm{Btu} / \mathrm{h} \bullet \mathrm{ft}^{2} \bullet \circ \mathrm{F}\right)\end{array}$ & $\begin{array}{c}\text { Wall } \\
\left(\mathrm{Btu} / \mathrm{h}^{2} \mathrm{ft}^{2} \bullet^{\circ} \mathrm{F}\right)\end{array}$ & $\begin{array}{c}\text { Slab } \\
\left(\mathrm{Btu} / \mathrm{h} \bullet \mathrm{ft} \bullet^{\circ} \mathrm{F}\right)\end{array}$ & $\begin{array}{c}\text { Floor } \\
\left(\mathrm{Btu} / \mathrm{h} \bullet \mathrm{ft}^{2} \bullet \circ \mathrm{F}\right)\end{array}$ & $\begin{array}{c}\text { Basement } \\
\left(\mathrm{Btu} / \mathrm{h} \bullet \mathrm{ft} \bullet{ }^{\circ} \mathrm{F}\right)\end{array}$ \\
\hline $\begin{array}{c}\text { State Average } \\
\text { (Nonelectric) }\end{array}$ & 0.034 & 0.173 & 0.767 & 0.054 & 1.112 \\
\hline $\begin{array}{c}\text { State Average } \\
\text { (Electric) }\end{array}$ & 0.034 & 0.117 & 0.767 & 0.054 & 1.112 \\
\hline MEC Average & 0.026 & 0.125 & 0.790 & 0.050 & 1.227 \\
\hline (a) Includes windows and doors.
\end{tabular}

The results of the duct analysis show duct losses associated with the Massachusetts code requirements to be $2.8 \%$ compared to duct losses of $1.8 \%$ associated with the 1992 MEC requirements.

Tables MA.4, MA.5, and MA.6 show the envelope requirements for the state code and for the 1992 MEC. 
Table MA.4. Massachusetts State Nonelectric Code Envelope Requirements

\begin{tabular}{||l|c||}
\hline Ceiling U-Value & 0.0342 \\
\hline Wall U-Value & 0.0829 \\
\hline Window U-Value & 0.65 \\
\hline Door U-Value & 0.40 \\
\hline Floor U-Value & 0.0537 \\
\hline Basement Wall R-Value & 12.5 \\
\hline Basement Depth & 8 \\
\hline Slab R-Value & 10 \\
\hline Slab Depth & 2 \\
\hline \hline
\end{tabular}

Table MA.5. Massachusetts State Electric Code Envelope Requirements

\begin{tabular}{||l|c||}
\hline Ceiling U-Value & 0.0342 \\
\hline Wall U-Value & 0.0574 \\
\hline Window U-Value & 0.40 \\
\hline Door U-Value & 0.40 \\
\hline Floor U-Value & 0.0537 \\
\hline Basement Wall R-Value & 12.5 \\
\hline Basement Depth & 8 \\
\hline Slab R-Value & 10 \\
\hline Slab Depth & 2 \\
\hline
\end{tabular}


Table MA.6. 1992 MEC Envelope Requirements for Massachusetts

\begin{tabular}{|l|c|c|c|c|c|c||}
\hline & $\begin{array}{c}\text { Ceiling } \\
\text { U-Value }\end{array}$ & $\begin{array}{c}\text { Wall } \\
\text { U-Value }\end{array}$ & $\begin{array}{c}\text { Floor } \\
\text { U-Value }\end{array}$ & $\begin{array}{c}\text { Basement } \\
\text { U-Value }\end{array}$ & $\begin{array}{c}\text { Slab } \\
\text { R-Value }\end{array}$ & $\begin{array}{c}\text { Slab } \\
\text { Depth }\end{array}$ \\
\hline Amherst & 0.0260 & 0.116 & 0.05 & 0.095 & 5.4 & 4 \\
\hline Boston & 0.0279 & 0.132 & 0.05 & 0.097 & 4.7 & 2 \\
\hline Brockton & 0.0279 & 0.132 & 0.05 & 0.097 & 4.7 & 2 \\
\hline Clinton & 0.0260 & 0.116 & 0.05 & 0.095 & 5.4 & 4 \\
\hline Fitchburg & 0.0260 & 0.116 & 0.05 & 0.095 & 5.4 & 4 \\
\hline Framingham & 0.0260 & 0.122 & 0.05 & 0.096 & 5.1 & 4 \\
\hline Haverhill & 0.0260 & 0.125 & 0.05 & 0.096 & 5.0 & 4 \\
\hline Lawrence & 0.0260 & 0.122 & 0.05 & 0.096 & 5.2 & 4 \\
\hline Lowell & 0.0260 & 0.122 & 0.05 & 0.096 & 5.2 & 4 \\
\hline New Bedford & 0.0293 & 0.136 & 0.05 & 0.098 & 4.5 & 2 \\
\hline Pittsfield & 0.0262 & 0.126 & 0.05 & 0.096 & 5.0 & 4 \\
\hline Springfield & 0.0262 & 0.126 & 0.05 & 0.096 & 5.0 & 4 \\
\hline Taunton & 0.0260 & 0.121 & 0.05 & 0.096 & 5.2 & 4 \\
\hline Worcester & 0.0260 & 0.111 & 0.05 & 0.094 & 5.6 & 4 \\
\hline
\end{tabular}

Table MA.7 shows the design information and housing starts for each of the cities used in the analysis.

Table MA.7. Design Information and Housing Starts for Massachusetts

\begin{tabular}{||l|c|c|c||}
\hline & HDD & $\begin{array}{c}\text { Design } \\
\text { Temperature }\end{array}$ & $\begin{array}{c}\text { Housing } \\
\text { Starts }\end{array}$ \\
\hline Amherst & 6,614 & -3 & 303 \\
\hline Boston & 5,596 & 9 & 2,330 \\
\hline Brockton & 5,596 & 9 & 1,947 \\
\hline Clinton & 6,596 & 2 & 0 \\
\hline Fitchburg & 6,620 & -1 & 1,178 \\
\hline Framingham. & 6,207 & 6 & 3,010 \\
\hline
\end{tabular}


Table MA.7. (contd)

\begin{tabular}{||l|c|c|c||}
\hline Haverhill & 6,027 & 2 & 3,745 \\
\hline Lawrence & 6,235 & 0 & 0 \\
\hline Lowell & 6,235 & 1 & 90 \\
\hline New Bedford & 5,311 & 9 & 66 \\
\hline Pittsfield & 5,955 & -3 & 54 \\
\hline Springfield & 5,955 & 0 & 1,507 \\
\hline Taunton & 6,277 & 9 & 2,109 \\
\hline Worcester & 6,951 & 4 & 0 \\
\hline
\end{tabular}




\section{Michigan}

The Michigan Department of Labor and Buildings Code Rules is the mandatory building code for new residential construction. The Michigan'code adopts the 1990 BOCA National Building Code (BOCA 1990a) by reference, which allows compliance by using ANSI/ASHRAE/IES Standard 90 A-1980 (ASHRAE 1980) or the 1989 MEC (CABO 1989). ANSI/ASHRAEIIES Standard 90A-1980 is significantly less stringent than the 1992 MEC (see Section 2.3 of this report). Therefore, the Michigan code does not meet the 1992 MEC requirements for one- and two-family dwellings. 


\section{Minnesota}

The Department of Public Service Minnesota Energy Code, Chapter 7670 is the mandatory state energy code for new residential construction. The Minnesota code was developed based on the 1989 MEC (CABO 1989). Building design by system analysis must comply with Chapter 4 of the 1989 MEC. Alternatively, compliance may be achieved using a prescriptive approach. The prescriptive approach gives separate $\mathrm{R}$-value requirements for each building component. The prescriptive path was used for this analysis.

The state code has a table that shows the allowed combinations of wall and window requirements. The different combinations are assumed to result in approximately equivalent energy use. The evaluated combination was a wall with R-13 wall insulation, R-7 sheathing, and a window U-value of 0.36 . This path allows $17.4 \%$ of the wall to be window and door area, which closely matched the prototype assumptions for window and door areas. An overall U-value comparison was performed.

Table MN.1 shows the overall envelope U-value for the state code and the 1992 MEC (CABO 1992). The overall state code U-value is lower than the overall MEC U-value. Therefore, the Minnesota code meets the 1992 MEC for one- and two-family dwellings.

Table MN.1. Average Overall Envelope U-Value for Minnesota

\begin{tabular}{||c|c|}
\hline & $\mathrm{U}_{\mathrm{o}}$ \\
\hline State Average & 0.061 \\
& (8\% below MEC average) \\
\hline MEC Average & 0.066 \\
\hline
\end{tabular}

Tables MN.2 and MN.3 show a more detailed comparison of the proposed state code to the 1992 MEC by the type of foundation insulation used and by envelope component. Table MN.2 also shows combined U-values, which are the average overall envelope U-values based on foundation type, averaged and weighted by the proportion of homes in the state with the given foundation type (percentages shown in parentheses). Table MN.3 shows the state average U-value for walls, ceilings, and floors over unheated spaces and the state average F-value for slab and basement walls. 
Table MN.2. Average Overall Envelope U-Values by Foundation Type for Proposed Minnesota Code

\begin{tabular}{|l|c|c|c|c|}
\hline & Slab (4\%) & $\begin{array}{c}\text { Floor Over Unheated } \\
\text { Space (83\%) }\end{array}$ & $\begin{array}{c}\text { Basement } \\
\text { Wall (13\%) }\end{array}$ & Combined \\
\hline State Average & 0.070 & 0.059 & 0.069 & 0.061 \\
\hline MEC Average & 0.077 & 0.065 & 0.071 & 0.066 \\
\hline
\end{tabular}

Table MN.3. Average Envelope Component U-Values or F-Values for Proposed Minnesota Code

\begin{tabular}{|c|c|c|c|c|c|}
\hline & $\begin{array}{c}\text { Ceiling } \\
\left(\mathrm{Btu} / \mathrm{h} \bullet \mathrm{ft}^{2} \bullet^{\circ} \mathrm{F}\right)\end{array}$ & $\begin{array}{c}\text { Wall } \\
\left(\mathrm{Btu} / \mathrm{h} \cdot \mathrm{ft}^{2} \bullet \circ \mathrm{F}\right)\end{array}$ & $\begin{array}{c}\text { Slab } \\
\left(\mathrm{Btu} / \mathrm{h} \cdot \mathrm{ft}{ }^{\circ} \mathrm{F}\right)\end{array}$ & $\begin{array}{c}\text { Floor } \\
\left(\mathrm{Btu} / \mathrm{h} \bullet \mathrm{ft}^{2} \bullet \circ \mathrm{F}\right)\end{array}$ & $\begin{array}{c}\text { Basement } \\
\left(\mathrm{Btu} / \mathrm{h} \cdot \mathrm{ft} \bullet^{\circ} \mathrm{F}\right)\end{array}$ \\
\hline $\begin{array}{l}\text { State } \\
\text { Average }\end{array}$ & 0.028 & 0.102 & 0.684 & 0.039 & 1.182 \\
\hline $\begin{array}{l}\text { MEC } \\
\text { Average }\end{array}$ & 0.026 & 0.110 & 0.794 & 0.050 & 1.184 \\
\hline
\end{tabular}

Tables MN.4 and MN.5 show the envelope requirements for the state code and for the 1992 MEC.

Table MN.4. Minnesota State Code Envelope Requirements

\begin{tabular}{||l|c||}
\hline Ceiling R-Value & 44 \\
\hline Wall Insulation R-Value & 13 \\
\hline Sheathing R-Value & 7 \\
\hline Window U-Value & 0.36 \\
\hline Door U-Value & 0.30 \\
\hline Floor R-Value & 24 \\
\hline Basement Wall R-Value & 10 \\
\hline Basement Depth & 8 \\
\hline Slab R-Value & 10 \\
\hline Slab Depth & 4 \\
\hline \hline
\end{tabular}


Table MN.5. 1992 MEC Envelope Requirements for Minnesota

\begin{tabular}{|l|c|c|c|c|c|c||}
\hline & $\begin{array}{c}\text { Ceiling } \\
\text { U-Value }\end{array}$ & $\begin{array}{c}\text { Wall } \\
\text { U-Value }\end{array}$ & $\begin{array}{c}\text { Floor } \\
\text { U-Value }\end{array}$ & $\begin{array}{c}\text { Basement } \\
\text { U-Value }\end{array}$ & $\begin{array}{c}\text { Slab } \\
\text { R-Value }\end{array}$ & $\begin{array}{c}\text { Slab } \\
\text { Depth }\end{array}$ \\
\hline Albert & 0.026 & 0.11 & 0.05 & 0.091 & 6.3 & 4 \\
\hline Austin & 0.026 & 0.11 & 0.05 & 0.091 & 6.3 & 4 \\
\hline Bemidji & 0.026 & 0.11 & 0.05 & 0.060 & 7.8 & 4 \\
\hline Cloquet & 0.026 & 0.11 & 0.05 & 0.060 & 7.4 & 4 \\
\hline Duluth & 0.026 & 0.11 & 0.05 & 0.060 & 7.6 & 4 \\
\hline Fairmont & 0.026 & 0.11 & 0.05 & 0.092 & 6.2 & 4 \\
\hline Faribault & 0.026 & 0.11 & 0.05 & 0.091 & 6.3 & 4 \\
\hline Fergus Falls & 0.026 & 0.11 & 0.05 & 0.060 & 7.0 & 4 \\
\hline Marshall & 0.026 & 0.11 & 0.05 & 0.091 & 6.4 & 4 \\
\hline Minneapolis & 0.026 & 0.11 & 0.05 & 0.091 & 6.3 & 4 \\
\hline Rochester & 0.026 & 0.11 & 0.05 & 0.091 & 6.5 & 4 \\
\hline St. Cloud & 0.026 & 0.11 & 0.05 & 0.062 & 7.0 & 4 \\
\hline St. Paul & 0.026 & 0.11 & 0.05 & 0.091 & 6.3 & 4 \\
\hline Virginia & 0.026 & 0.11 & 0.05 & 0.060 & 7.6 & 4 \\
\hline Willmar & 0.026 & 0.11 & 0.05 & 0.090 & 6.6 & 4 \\
\hline \hline
\end{tabular}

Table MN.6 shows the design information and housing starts for each of the cities used in the analysis. 
Table MN.6. Design Information and Housing Starts for Minnesota

\begin{tabular}{||l|c|c|c||}
\hline & HDD & $\begin{array}{c}\text { Design } \\
\text { Temperature }\end{array}$ & $\begin{array}{c}\text { Housing } \\
\text { Starts }\end{array}$ \\
\hline Albert & 7,969 & -7 & 40 \\
\hline Austin & 7,985 & -6 & 33 \\
\hline Bemidji & 10,207 & -26 & 21 \\
\hline Cloquet & 9,582 & -17 & 0 \\
\hline Duluth & 9,906 & -16 & 794 \\
\hline Fairmont & 7,870 & -9 & 410 \\
\hline Faribault & 7,987 & -6 & 676 \\
\hline Fergus Falls & 8,998 & -17 & 771 \\
\hline Marshall & 8,126 & -12 & 1,353 \\
\hline Minneapolis & 8,010 & -14 & 8,631 \\
\hline Rochester & 8,279 & -12 & 5,488 \\
\hline St. Cloud & 8,973 & -11 & 2,469 \\
\hline St. Paul & 8,010 & -14 & 4,762 \\
\hline Virginia & 9,848 & -21 & 85 \\
\hline Willmar & 8,333 & -11 & 333 \\
\hline \hline
\end{tabular}




\section{Mississippi}

The Mississippi State Code for Energy Conservation in New Building Construction is the mandatory state energy code for Mississippi. The Mississippi code has a single set of prescriptive U-value thermal envelope requirements. An overall U-value comparison was performed. Door U-value requirements are not given in the state code, so a U-value of 0.60 was assumed for the analysis.

Table MS. 1 shows the average overall envelope U-value for the state code and the 1992 MEC. The average overall $\mathrm{U}$-value for the state code is higher than the average overall MEC U-value. Therefore, the Mississippi code does not meet the 1992 MEC requirements for one- and two-family dwellings.

Table MS.1. Average Overall Envelope U-Value for Mississippi

\begin{tabular}{|l|c|}
\hline & $\mathrm{U}_{0}$ \\
\hline State Average & 0.122 \\
& $(8 \%$ above MEC average $)$ \\
\hline MEC Average & 0.113 \\
\hline
\end{tabular}

Tables MS. 2 and MS. 3 show a more detailed comparison of the state code to the 1992 MEC by the type of foundation insulation used and by envelope component. Table MS.2 also shows combined Uvalues, which are the average overall envelope U-values based on foundation type, averaged and weighted by the proportion of homes in the state with the given foundation type (percentages shown in parentheses). Table MS.3 shows the state average U-value for walls, ceilings, and floors over unheated spaces and the state average F-value for slab and basement walls.

Table MS.2. Average Overall Envelope U-Values by Foundation Type for Mississippi

\begin{tabular}{||l|c|c|c|c||}
\hline & Slab (97\%) & $\begin{array}{c}\text { Floor Over Unheated } \\
\text { Space (2\%) }\end{array}$ & $\begin{array}{c}\text { Basement } \\
\text { Wall (0\%) }\end{array}$ & Combined \\
\hline State Average & 0.123 & 0.119 & 0.138 & 0.122 \\
\hline MEC Average & 0.114 & 0.102 & 0.110 & 0.113 \\
\hline
\end{tabular}


Table MS.3. Average Envelope Component U-Values or F-Values for Mississippi

\begin{tabular}{||l|c|c|c|c|c||}
\hline & $\begin{array}{c}\text { Ceiling } \\
\left(\mathrm{Btu} / \mathrm{h} \bullet \mathrm{ft}^{2} \bullet^{\circ} \mathrm{F}\right)\end{array}$ & $\begin{array}{c}\text { Wall } \\
\left(\mathrm{Btu} / \mathrm{h} \bullet \mathrm{ft}^{2} \bullet{ }^{\circ} \mathrm{F}\right)\end{array}$ & $\begin{array}{c}\text { Slab } \\
\left(\mathrm{Btu} / \mathrm{h} \bullet \mathrm{ft} \bullet^{\circ} \mathrm{F}\right)\end{array}$ & $\begin{array}{c}\text { Floor } \\
\left(\mathrm{Btu} / \mathrm{h} \bullet \mathrm{ft}^{2} \bullet{ }^{\circ} \mathrm{F}\right)\end{array}$ & $\begin{array}{c}\text { Basement } \\
\left(\mathrm{Btu} / \mathrm{h} \bullet \mathrm{ft} \bullet^{\circ} \mathrm{F}\right)\end{array}$ \\
\hline $\begin{array}{l}\text { State } \\
\text { Average }\end{array}$ & 0.033 & 0.204 & 1.042 & 0.100 & 2.584 \\
\hline $\begin{array}{l}\text { MEC } \\
\text { Average }\end{array}$ & 0.043 & 0.186 & 0.889 & 0.059 & 1.639 \\
\hline (a) Includes windows and doors.
\end{tabular}

Tables MS.4 and MS.5 show the envelope requirements for the state code and for the 1992 MEC.

Table MS.4. Mississippi State Code Envelope Requirements

\begin{tabular}{||l|c|}
\hline Ceiling U-Value & 0.033 \\
\hline Gross Wall U-Value & 0.204 \\
\hline Floor U-Value & 0.100 \\
\hline Basement Wall R-Value & 0 \\
\hline Slab R-Value & 0 \\
\hline
\end{tabular}

Table MS.5. 1992 MEC Envelope Requirements for Mississippi

\begin{tabular}{||l|c|c|c|c|c|c||}
\hline & $\begin{array}{c}\text { Ceiling } \\
\text { U-Value }\end{array}$ & $\begin{array}{c}\text { Wall } \\
\text { U-Value }\end{array}$ & $\begin{array}{c}\text { Floor } \\
\text { U-Value }\end{array}$ & $\begin{array}{c}\text { Basement } \\
\text { U-Value }\end{array}$ & $\begin{array}{c}\text { Slab } \\
\text { R-Value }\end{array}$ & $\begin{array}{c}\text { Slab } \\
\text { Depth }\end{array}$ \\
\hline Biloxi & 0.0476 & 0.220 & 0.07 & - & 0 & - \\
\hline Brookhaven & 0.0449 & 0.197 & 0.07 & 0.157 & 0 & - \\
\hline Canton & 0.0425 & 0.179 & 0.05 & 0.145 & 4 & 2 \\
\hline Clarksdale & 0.0405 & 0.173 & 0.05 & 0.136 & 4 & 2 \\
\hline Cleveland & 0.0408 & 0.173 & 0.05 & 0.137 & 4 & 2 \\
\hline Columbus & 0.0410 & 0.174 & 0.05 & 0.138 & 4 & 2 \\
\hline Corinth & 0.0394 & 0.169 & 0.05 & 0.130 & 4 & 2 \\
\hline
\end{tabular}


Table MS.5. (contd)

\begin{tabular}{||l|c|c|c|c|c|c||}
\hline & $\begin{array}{c}\text { Ceiling } \\
\text { U-Value }\end{array}$ & $\begin{array}{c}\text { Wall } \\
\text { U-Value }\end{array}$ & $\begin{array}{c}\text { Floor } \\
\text { U-Value }\end{array}$ & $\begin{array}{c}\text { Basement } \\
\text { U-Value }\end{array}$ & $\begin{array}{c}\text { Slab } \\
\text { R-Value }\end{array}$ & $\begin{array}{c}\text { Slab } \\
\text { Depth }\end{array}$ \\
\hline Greenville & 0.0421 & 0.178 & 0.05 & 0.144 & 4 & 2 \\
\hline Greenwood & 0.0417 & 0.177 & 0.05 & 0.142 & 4 & 2 \\
\hline Gulfport & 0.0474 & 0.218 & 0.07 & 0.169 & 0 & - \\
\hline Hattiesburg & 0.0451 & 0.199 & 0.07 & 0.158 & 0 & - \\
\hline Jackson & 0.0433 & 0.184 & 0.07 & 0.149 & 0 & - \\
\hline Laurel & 0.0438 & 0.188 & 0.07 & 0.152 & 0 & - \\
\hline Meridian & 0.0429 & 0.181 & 0.07 & 0.147 & 0 & - \\
\hline Nachez & 0.0455 & 0.202 & 0.07 & 0.160 & 0 & - \\
\hline Picayune & 0.0471 & 0.216 & 0.07 & 0.168 & 0 & - \\
\hline Tupelo & 0.0399 & 0.171 & 0.05 & 0.133 & 4 & 2 \\
\hline Vicksburg & 0.0442 & 0.192 & 0.07 & 0.154 & 0 & - \\
\hline Yazoo City & 0.0429 & 0.181 & 0.07 & 0.147 & 0 & - \\
\hline
\end{tabular}

Table MS.6 shows the design information and housing starts for each of the cities used in the analysis.

Table MS.6. Design Information and Housing Starts for Mississippi

\begin{tabular}{|l|c|c|c||}
\hline & HDD & $\begin{array}{c}\text { Design } \\
\text { Temperature }\end{array}$ & $\begin{array}{c}\text { Housing } \\
\text { Starts }\end{array}$ \\
\hline Biloxi & 1,499 & 31 & 1,167 \\
\hline Brookhaven & 2,070 & 36 & 56 \\
\hline Canton & 2,568 & 24 & 825 \\
\hline Clarksdale & 2,972 & 19 & 148 \\
\hline Cleveland & 2,922 & 30 & 73 \\
\hline Columbus & 2,868 & 20 & 149 \\
\hline Corinth & 3,216 & 19 & 1,344 \\
\hline Greenville & 2,636 & 20 & 74 \\
\hline
\end{tabular}


Table MS.6. (contd)

\begin{tabular}{||l|c|c|c||}
\hline & HDD & $\begin{array}{c}\text { Design } \\
\text { Temperature }\end{array}$ & $\begin{array}{c}\text { Housing } \\
\text { Starts }\end{array}$ \\
\hline Greenwood & 2,720 & 20 & 79 \\
\hline Gulfport & 1,540 & 32 & 0 \\
\hline Hattiesburg & 2,026 & 27 & 69 \\
\hline Jackson & 2,390 & 25 & 945 \\
\hline Laurel & 2,295 & 27 & 14 \\
\hline Meridian & 2,478 & 23 & 165 \\
\hline Nachez & 1,941 & 27 & 0 \\
\hline Picayune & 1,609 & 30 & 62 \\
\hline Tupelo & 3,097 & 19 & 479 \\
\hline Vicksburg & 2,200 & 26 & 110 \\
\hline Yazoo City & 2,485 & 25 & 0 \\
\hline
\end{tabular}




\section{Missouri}

Missouri has not adopted a state residential energy code. Therefore, the state does not meet the 1992 MEC (CABO 1992) requirements for one- and two-family dwellings. 


\section{Montana}

The Administrative Rules for Montana is the state building code for new residential construction. The Montana code applies to all new construction. The code references the 1992 MEC (CABO 1992) with amendments. The amendments include two sets of prescriptive path $\mathrm{R}$-value requirements. Additional allowable prescriptive paths are available from the Building Codes Bureau in Helena.

An overall U-value comparison was performed. All of the prescriptive paths were assumed to result in approximately equivalent energy use. The requirements from the equivalent path were used for the Uvalue comparison. A basement wall insulation depth requirement was not specified, so a depth of $8 \mathrm{ft}$ was assumed.

Table MT.1 shows the average overall envelope U-value for the state code and the $1992 \mathrm{MEC}$. The average overall state code $U$-value is slightly lower than the average overall MEC U-value. Because it is within 5\% of the overall MEC U-value, the Montana code has been classified as marginally meeting the 1992 MEC for one- and two-family dwellings.

Table MT.1. Average Overall Envelope U-Value for Montana

\begin{tabular}{||c|c|}
\hline \hline & $\mathrm{U}_{0}$ \\
\hline State Average & 0.065 \\
& $(1 \%$ below MEC average $)$ \\
\hline MEC Average & 0.066 \\
\hline
\end{tabular}

Tables MT.2 and MT.3 show a more detailed comparison of the state code to the 1992 MEC by the type of foundation insulation used and by envelope component. Table MT.2 also shows combined Uvalues, which are the average overall envelope $U$-values based on foundation type, averaged and weighted by the proportion of homes in the state with the given foundation type (percentages shown in parentheses). Table MT.3 shows the state average U-value for walls, ceilings, and floors over unheated spaces and the state average F-value for slab and basement walls. 
Table MT.2. Average Overall Envelope U-Values by Foundation Type for Montana

\begin{tabular}{||c|c|c|c|c||}
\hline \hline & Slab (0\%) & $\begin{array}{c}\text { Floor Over Unheated } \\
\text { Space (100\%) }\end{array}$ & $\begin{array}{c}\text { Basement } \\
\text { Wall (0\%) }\end{array}$ & Combined \\
\hline State Average & 0.086 & 0.065 & 0.071 & 0.065 \\
\hline MEC Average & 0.077 & 0.066 & 0.072 & 0.066 \\
\hline
\end{tabular}

Table MT.3. Average Envelope Component U-Values for Montana

\begin{tabular}{|l|c|c|c|c|c||}
\hline & $\begin{array}{c}\text { Ceiling } \\
\left(\mathrm{Btu} / \mathrm{h} \bullet \mathrm{ft}^{2} \bullet \circ \mathrm{F}\right)\end{array}$ & $\begin{array}{c}\mathrm{Wall}^{(\mathrm{a})} \\
\left(\mathrm{Btu} / \mathrm{h} \cdot \mathrm{ft}^{2} \cdot \circ \mathrm{F}\right)\end{array}$ & $\begin{array}{c}\text { Slab } \\
\left(\mathrm{Btu} / \mathrm{h} \cdot \mathrm{ft} \bullet^{\circ} \mathrm{F}\right)\end{array}$ & $\begin{array}{c}\text { Floor } \\
\left(\mathrm{Btu} / \mathrm{h} \cdot \mathrm{ft}^{2} \cdot{ }^{\circ} \mathrm{F}\right)\end{array}$ & $\begin{array}{c}\text { Basement } \\
\left(\mathrm{Btu} / \mathrm{h} \bullet \mathrm{ft} \bullet^{\circ} \mathrm{F}\right)\end{array}$ \\
\hline $\begin{array}{l}\text { State } \\
\text { Average }\end{array}$ & 0.030 & 0.108 & 1.042 & 0.047 & 1.182 \\
\hline $\begin{array}{l}\text { MEC } \\
\text { Average }\end{array}$ & 0.026 & 0.110 & 0.796 & 0.050 & 1.205 \\
\hline \multicolumn{1}{|l}{ (a) Includes windows and doors. } \\
\hline
\end{tabular}

Tables MT.4 and MT.5 show the envelope requirements for the state code and for the 1992 MEC.

Table MT.4. Montana State Code Envelope Requirements

\begin{tabular}{||l|c|}
\hline Ceiling R-Value & 38 \\
\hline Wall R-Value & 19 \\
\hline Window U-Value & 0.40 \\
\hline Door R-Value & 5 \\
\hline Floor R-Value & 19 \\
\hline Basement Wall R-Value & 10 \\
\hline Basement Depth & 8 \\
\hline Slab R-Value & 0.0 \\
\hline Slab Depth & - \\
\hline
\end{tabular}


Table MT.5. 1992 MEC Envelope Requirements for Montana

\begin{tabular}{|l|c|c|c|c|c|c|}
\hline & $\begin{array}{c}\text { Ceiling } \\
\text { U-Value }\end{array}$ & $\begin{array}{c}\text { Wall } \\
\text { U-Value }\end{array}$ & $\begin{array}{c}\text { Floor } \\
\text { U-Value }\end{array}$ & $\begin{array}{c}\text { Basement } \\
\text { U-Value }\end{array}$ & $\begin{array}{c}\text { Slab } \\
\text { R-Value }\end{array}$ & $\begin{array}{c}\text { Slab } \\
\text { Depth }\end{array}$ \\
\hline Billings & 0.026 & 0.112 & 0.05 & 0.094 & 5.6 & 4 \\
\hline Bozeman & 0.026 & 0.110 & 0.05 & 0.091 & 6.3 & 4 \\
\hline Butte & 0.026 & 0.110 & 0.05 & 0.060 & 7.4 & 4 \\
\hline Great Falls & 0.026 & 0.110 & 0.05 & 0.092 & 6.2 & 4 \\
\hline Havre & 0.026 & 0.110 & 0.05 & 0.079 & 6.8 & 4 \\
\hline Helena & 0.026 & 0.110 & 0.05 & 0.091 & 6.5 & 4 \\
\hline Kalispell & 0.026 & 0.110 & 0.05 & 0.092 & 6.1 & 4 \\
\hline Missoula & 0.026 & 0.110 & 0.05 & 0.092 & 6.2 & 4 \\
\hline \hline
\end{tabular}

Table MT.6 shows the design information and housing starts for each of the cities used in the analysis.

Table MT.6. Design Information and Housing Starts for Montana

\begin{tabular}{|l|c|c|c||}
\hline & HDD & $\begin{array}{c}\text { Design } \\
\text { Temperature }\end{array}$ & $\begin{array}{c}\text { Housing } \\
\text { Starts }\end{array}$ \\
\hline Billings & 6,875 & -10 & 471 \\
\hline Bozeman & 8,002 & -14 & 244 \\
\hline Butte & 9,613 & -17 & 63 \\
\hline Great Falls & 7,784 & -15 & 136 \\
\hline Havre & 8,684 & -11 & 9 \\
\hline Helena & 8,186 & -16 & 177 \\
\hline Kalispell & 7,712 & -7 & 390 \\
\hline Missoula & 7,844 & -6 & 535 \\
\hline
\end{tabular}




\section{Nebraska}

The Nebraska Building Energy Conservation Standard is the state energy code for new residential construction, which adopts the 1983 MEC (CABO 1983) by reference. The 1983 MEC allows for compliance using ANSI/ASHRAE/IES Standard 90A-1980 (ASHRAE 1980). ANSI/ASHRAEIIES Standard 90A-1980 is substantially less stringent than the 1992 MEC (CABO 1992) (see Section 2.3 of this report). Therefore, the Nebraska code does not meet the 1992 MEC requirements for one- and two-family dwellings. 


\section{Nevada}

The Nevada Administrative Code is the state building code for Nevada. The code applies to all jurisdictions that had not adopted an energy code at the time this code was adopted. The Nevada code adopts the 1986 MEC (CABO 1986) by reference. The 1986 MEC envelope requirements are the same as the envelope requirements for ANSI/ASHRAE/IES Standard 90A-1980 (ASHRAE 1980). ANSI/ASHRAEIIES Standard 90A-1980 is substantially less stringent than the 1992 MEC (CABO 1992) (see Section 2.3 of this report). Therefore, Nevada does not meet the 1992 MEC requirements for one- and two-family dwellings. 


\section{New Hampshire}

The New Hampshire Energy Code is the mandatory state energy code for new residential construction. The New Hampshire code gives a single set of prescriptive U-value requirements that apply to the whole state. The state code has different requirements for basement wall insulation depending on whether the basement is conditioned. Different requirements are also given for floors over unheated spaces depending on the type of unheated space; e.g., vented crawl space, unconditioned basement. Assumptions were made to favor the code in order to definitively classify the state code as not meeting the 1992 MEC (CABO 1992) regardless of the construction configuration.

An overall U-value comparison was performed. Basements were assumed to be conditioned and insulated floors were assumed to be over vented crawl spaces. Basement wall insulation depth requirements were not given, so a depth of $8 \mathrm{ft}$ was assumed for the analysis.

Table NH.1 shows the average overall envelope U-value for the state code and the $1992 \mathrm{MEC}$. The average overall U-value for the state code is higher than the average overall MEC U-value. Therefore, the New Hampshire code does not meet the 1992 MEC requirements for one- and two-family dwellings.

Table NH.1. Average Overall Envelope U-Value for New Hampshire

\begin{tabular}{||c|c|}
\hline & $\mathrm{U}_{\mathrm{o}}$ \\
\hline State Average & 0.078 \\
& $(16 \%$ above MEC average $)$ \\
\hline MEC Average & 0.067 \\
\hline
\end{tabular}

Tables NH. 2 and NH.3 show a more detailed comparison of the state code to the 1992 MEC by the type of foundation insulation used and by envelope component. Table NH.2 also shows combined Uvalues, which are the average overall envelope $U$-values based on foundation type, averaged and weighted by the proportion of homes in the state with the given foundation type (percentages shown in parentheses). Table NH.3 shows the state average U-value for walls, ceilings, and floors over unheated spaces and the state average F-value for slab and basement walls. 
Table NH.2. Average Overall Envelope U-Values by Foundation Type for New Hampshire

\begin{tabular}{||l|c|c|c|c||}
\hline \hline & Slab (1\%) & $\begin{array}{c}\text { Floor Over Unheated } \\
\text { Space (64\%) }\end{array}$ & $\begin{array}{c}\text { Basement } \\
\text { Wall (35\%) }\end{array}$ & Combined \\
\hline State Average & 0.090 & 0.079 & 0.077 & 0.078 \\
\hline MEC Average & 0.077 & 0.065 & 0.072 & 0.067 \\
\hline
\end{tabular}

Table NH.3. Average Envelope Component U-Values for New Hampshire

\begin{tabular}{|l|c|c|c|c|c||}
\hline & $\begin{array}{c}\text { Ceiling } \\
\left(\mathrm{Btu} / \mathrm{h} \bullet \mathrm{ft}^{2} \bullet \circ \mathrm{F}\right)\end{array}$ & $\begin{array}{c}\text { Wall } \\
\left(\mathrm{Btu} / \mathrm{h} \bullet \mathrm{ft}^{2} \bullet{ }^{\circ} \mathrm{F}\right)\end{array}$ & $\begin{array}{c}\text { Slab } \\
\left(\mathrm{Btu} / \mathrm{h} \bullet \mathrm{ft} \bullet^{\circ} \mathrm{F}\right)\end{array}$ & $\begin{array}{c}\text { Floor } \\
\left(\mathrm{Btu} / \mathrm{h} \bullet \mathrm{ft}^{2} \bullet \circ \mathrm{F}\right)\end{array}$ & $\begin{array}{c}\text { Basement } \\
\left(\mathrm{Btu} / \mathrm{h} \bullet \mathrm{ft} \bullet{ }^{\circ} \mathrm{F}\right)\end{array}$ \\
\hline $\begin{array}{l}\text { State } \\
\text { Average }\end{array}$ & 0.035 & 0.14 & 0.767 & 0.047 & 1.020 \\
\hline $\begin{array}{l}\text { MEC } \\
\text { Average }\end{array}$ & 0.026 & 0.11 & 0.804 & 0.050 & 1.211 \\
\hline (a) Includes windows and doors.
\end{tabular}

Tables NH.4 and NH.5 show the envelope requirements for the state code and for the 1992 MEC.

Table NH.4. New Hampshire State Code Envelope Requirements

\begin{tabular}{||l|c|}
\hline Ceiling R-Value & 30 \\
\hline Wall R-Value & 18 \\
\hline Window U-Value & 0.55 \\
\hline Door U-Value & 0.33 \\
\hline Floor R-Value & 19 \\
\hline Basement Wall R-Value & 18 \\
\hline Basement Depth & 8 \\
\hline Slab R-Value & 10 \\
\hline Slab Depth & 2 \\
\hline
\end{tabular}


Table NH.5. 1992 MEC Envelope Requirements for New Hampshire

\begin{tabular}{|l|c|c|c|c|c|c||}
\hline & $\begin{array}{c}\text { Ceiling } \\
\text { U-Value }\end{array}$ & $\begin{array}{c}\text { Wall } \\
\text { U-Value }\end{array}$ & $\begin{array}{c}\text { Floor } \\
\text { U-Value }\end{array}$ & $\begin{array}{c}\text { Basement } \\
\text { U-Value }\end{array}$ & $\begin{array}{c}\text { Slab } \\
\text { R-Value }\end{array}$ & $\begin{array}{c}\text { Slab } \\
\text { Depth }\end{array}$ \\
\hline Concord & 0.026 & 0.11 & 0.05 & 0.093 & 6.0 & 4 \\
\hline Keene & 0.026 & 0.11 & 0.05 & 0.094 & 5.7 & 4 \\
\hline Lebanon & 0.026 & 0.11 & 0.05 & 0.091 & 6.3 & 4 \\
\hline Manchester & 0.026 & 0.11 & 0.05 & 0.093 & 6.0 & 4 \\
\hline Nashua & 0.026 & 0.11 & 0.05 & 0.094 & 5.7 & 4 \\
\hline
\end{tabular}

Table NH.6 shows the design information and housing starts for each of the cities used in the analysis.

Table NH.6. Design Information and Housing Starts for New Hampshire

\begin{tabular}{|l|c|c|c||}
\hline & HDD & $\begin{array}{c}\text { Design } \\
\text { Temperature }\end{array}$ & $\begin{array}{c}\text { Housing } \\
\text { Starts }\end{array}$ \\
\hline Concord & 7,483 & -3 & 927 \\
\hline Keene & 7,037 & -7 & 108 \\
\hline Lebanon & 7,940 & -7 & 114 \\
\hline Manchester & 7,483 & -3 & 2,389 \\
\hline Nashua & 7,082 & 4 & 105 \\
\hline
\end{tabular}




\section{New Jersey}

The New Jersey Uniform Construction Code is the state building code for New Jersey. The New Jersey code adopts by reference the 1993 BOCA National Building Code (BOCA 1993), which allows for compliance using ANSI/ASHRAE/IES Standard 90A-1980 or the 1992 MEC (CABO 1992).

ANSI/ASHRAEIIES Standard 90A-1980 is substantially less stringent than the $1992 \mathrm{MEC}$ (see Section 2.3 of this report). Therefore, the New Jersey code does not meet the 1992 MEC requirements for one- and two-family dwellings. 


\section{New Mexico}

The 1991 New Mexico Building Code is the mandatory state building code for New Mexico. The New Mexico code adopts by reference the 1989 MEC (CABO 1989) without amendments. Because the 1992 MEC (CABO 1992) and the 1989 MEC have nearly the same energy criteria, the New Mexico code meets the 1992 MEC requirements for one- and two-family and dwellings. 


\section{New York}

The New York State Energy Conservation Construction Code, with Amendments is the mandatory state energy code for New York. The New York code allows for compliance by one of three methods: annual energy analysis, acceptable practice, or thermal rating method. The methods were assumed to result in approximately the same energy consumption. The acceptable practice method was chosen for analysis because it was the path most amendable to our methodology.

The acceptable practice method gives R-value envelope requirements that are different for electric and nonelectric homes. Requirements also vary by heating degree-days (HDDs). The counties in the state are classified into one of five HDD groups. These groups correspond to 5000, 6000, 7000, 8000, and $9000 \mathrm{HDD}$. The requirements for the 5000 and $6000 \mathrm{HDD}$ groups are the same as are the requirements for the 7000 and $8000 \mathrm{HDD}$ regions. The requirements for the $9000 \mathrm{HDD}$ regions are the same as those for the 7000 and 8000 regions, except for the basement wall insulation depth requirement.

An overall U-value comparison was performed, with electric and nonelectric portions of the code evaluated separately. The $U$-values for the different degree-day regions were averaged and weighted according to housing starts to derive at a state overall $U$-value.

Tables NY.1 and NY.2 show the average overall U-values for the nonelectric and electric portions of the state code. The average overall U-value for the state nonelectric code is higher than the average overall 1992 MEC (CABO 1992) U-value. Therefore, the New York nonelectric code is classified as not meeting the $1992 \mathrm{MEC}$ requirements for one- and two-family dwellings. The overall U-value for the state electric code is lower than the average overall 1992 MEC U-value. Therefore, the New York electric code is classified as meeting the 1992 MEC requirements for one- and two-family dwellings.

Table NY.1. Average Overall Nonelectric Code Envelope U-Values for Regions of New York

\begin{tabular}{||l|c|c||}
\hline \multicolumn{1}{|c|}{ Region } & $U_{0}$ & Housing Starts (\%) \\
\hline 5,000 and 6,000 HDD & 0.098 & 45 \\
\hline 7,000 and 8,00 HDD & 0.089 & 55 \\
\hline 9,000 HDD & 0.085 & 0. \\
\hline State A'verage & $\begin{array}{c}0.093 \\
\text { (26\% above MEC avg.) }\end{array}$ & \\
\hline MEC Average & 0.074 & \\
\hline \hline
\end{tabular}


Table NY.2. Average Overall Electric Code Envelope U-Values for Regions for New York

\begin{tabular}{||l|c|c||}
\hline \multicolumn{1}{|c|}{ Region } & $\mathrm{U}_{0}$ & Housing Starts (\%) \\
\hline 5000 and 6000 HDD & 0.071 & 45 \\
\hline 7000 and 8000 HDD & 0.068 & 55 \\
\hline $9000 \mathrm{HDD}$ & 0.068 & 0 \\
\hline State Average & 0.069 & \\
\hline MEC Average & $(7 \%$ below MEC avg.) & \\
\hline
\end{tabular}

Tables NY.3, NY.4, NY.5, and NY.6 show a more detailed comparison of the state code to the 1992 MEC by the type of foundation insulation used and by envelope component. Tables NY.3 and NY.4 also show combined U-values, which are the average overall envelope $U$-values based on foundation type, averaged and weighted by the proportion of homes in the state with the given foundation type (percentages shown in parentheses). Table NY.3 shows the state average U-value for walls, ceilings, and floors over unheated spaces and the state average F-value for slab and basement walls.

Table NY.3. Average Overall Nonelectric Code Envelope U-Values by Foundation Type for New York

\begin{tabular}{||l|c|c|c|c|}
\hline \hline & Slab (2\%) & $\begin{array}{c}\text { Floor Over Unheated } \\
\text { Space (46\%) }\end{array}$ & $\begin{array}{c}\text { Basement } \\
\text { Wall (52\%) }\end{array}$ & Combined \\
\hline 5000 and 6000 HDD & 0.098 & 0.086 & 0.108 & 0.098 \\
\hline 7000 and 8000 HDD & 0.095 & 0.084 & 0.094 & 0.089 \\
\hline 9000 HDD & 0.095 & 0.084 & 0.086 & 0.085 \\
\hline State Average & 0.096 & 0.085 & 0.101 & 0.093 \\
\hline MEC Average & 0.082 & 0.071 & 0.077 & 0.074 \\
\hline
\end{tabular}


Table NY.4. Average Overall Electric Code Envelope U-Values by Foundation Type for New York

\begin{tabular}{||l|c|c|c|c||}
\hline & Slab (2\%) & $\begin{array}{c}\text { Floor Over Unheated } \\
\text { Space (46\%) }\end{array}$ & $\begin{array}{c}\text { Basement } \\
\text { Wall (52\%) }\end{array}$ & Combined \\
\hline 5000 and 6000 HDD & 0.079 & 0.068 & 0.073 & 0.071 \\
\hline 7000 and 8000 HDD & 0.077 & 0.063 & 0.072 & 0.068 \\
\hline $9000 \mathrm{HDD}$ & 0.077 & 0.063 & 0.072 & 0.068 \\
\hline State Average & 0.078 & 0.065 & 0.072 & 0.069 \\
\hline MEC Average & 0.082 & 0.071 & 0.077 & 0.074 \\
\hline
\end{tabular}

Table NY.5. Average Nonelectric Envelope Component U-Values or F-Values for New York

\begin{tabular}{|c|c|c|c|c|c|}
\hline Region & $\begin{array}{c}\text { Wall } \\
\left(\mathrm{Btu} / \mathrm{h} \bullet{ }^{\circ} \mathrm{F} \bullet \mathrm{ft}^{2}\right)\end{array}$ & $\begin{array}{c}\text { Ceiling } \\
\left(\mathrm{Btu} / \mathrm{h} \bullet^{\circ} \mathrm{F} \bullet \mathrm{ft}^{2}\right)\end{array}$ & $\begin{array}{c}\text { Floor } \\
\left(\mathrm{Btu} / \mathrm{h} \bullet^{\circ} \mathrm{F} \bullet \mathrm{ft}^{2}\right)\end{array}$ & $\begin{array}{c}\text { Slab } \\
\left(\mathrm{Btu} / \mathrm{h} \bullet \mathrm{ft} \bullet^{\circ} \mathrm{F}\right)\end{array}$ & $\begin{array}{c}\text { Basement } \\
\left(\mathrm{Btu} / \mathrm{h} \bullet \mathrm{ft} \bullet^{\circ} \mathrm{F}\right)\end{array}$ \\
\hline $\begin{array}{l}5000 \text { and } 6000 \\
\text { HDD }\end{array}$ & 0.147 & 0.051 & 0.047 & 0.767 & 1.954 \\
\hline $\begin{array}{l}7000 \text { and } 8000 \\
\text { HDD }\end{array}$ & 0.147 & 0.042 & 0.047 & 0.767 & 1.510 \\
\hline $9000 \mathrm{HDD}$ & 0.147 & 0.042 & 0.047 & 0.767 & 1.182 \\
\hline State Average & 0.147 & 0.046 & 0.047 & 0.767 & 1.709 \\
\hline MEC Average & 0.124 & 0.028 & 0.050 & 0.786 & 1.226 \\
\hline
\end{tabular}


Table NY.6. Electric Average Envelope Component U-Values or F-Values for New York

\begin{tabular}{||l|c|c|c|c|c||}
\hline & $\begin{array}{c}\text { Wall } \\
\left(\mathrm{Btu} / \mathrm{h} \bullet^{\circ} \mathrm{F} \bullet \mathrm{ft}^{2}\right)\end{array}$ & $\begin{array}{c}\text { Ceiling } \\
\left(\mathrm{Btu} / \mathrm{h} \cdot{ }^{\circ} \mathrm{F} \bullet \mathrm{ft}^{2}\right)\end{array}$ & $\begin{array}{c}\text { Floor } \\
\left(\mathrm{Btu} / \mathrm{h} \bullet^{\circ} \mathrm{F} \bullet \mathrm{ft}^{2}\right)\end{array}$ & $\begin{array}{c}\text { Slab } \\
\left(\mathrm{Btu} / \mathrm{h} \bullet \mathrm{ft} \bullet{ }^{\circ} \mathrm{F}\right)\end{array}$ & $\begin{array}{c}\text { Basement } \\
\left(\mathrm{Btu} / \mathrm{h} \bullet \mathrm{ft} \bullet^{\circ} \mathrm{F}\right)\end{array}$ \\
\hline $\begin{array}{l}5000 \text { and } 6000 \\
\mathrm{HDD}\end{array}$ & 0.107 & 0.039 & 0.047 & 0.767 & 1.182 \\
\hline $\begin{array}{l}7000 \text { and } 8000 \\
\mathrm{HDD}\end{array}$ & 0.107 & 0.033 & 0.039 & 0.767 & 1.182 \\
\hline 9000 HDD & 0.107 & 0.033 & 0.039 & 0.767 & 1.182 \\
\hline State Average & 0.107 & 0.036 & 0.043 & 0.767 & 1.182 \\
\hline MEC Average & 0.124 & 0.028 & 0.050 & 0.786 & 1.226 \\
\hline (a) Includes windows and doors. & & & \\
\hline
\end{tabular}

The results of the duct analysis showed duct losses associated with the New York code requirements to be $3.5 \%$ compared to duct losses of $1.8 \%$ associated with the 1992 MEC requirements.

Tables NY.7, NY.8, and NY.9 show the state nonelectric and electric code and the 1992 MEC envelope requirements.

Table NY.7. New York State Nonelectric Code Envelope Requirements

\begin{tabular}{||l|c|c|c|c|c|c|c|c|c||}
\hline \multicolumn{1}{|c|}{ Region } & $\begin{array}{c}\text { Ceiling } \\
\text { R-Value }\end{array}$ & $\begin{array}{c}\text { Wall } \\
\text { R-Value }\end{array}$ & $\begin{array}{c}\text { Window } \\
\text { U-Value }\end{array}$ & $\begin{array}{c}\text { Door } \\
\text { U-Value }\end{array}$ & $\begin{array}{c}\text { Floor } \\
\text { R-Value }\end{array}$ & $\begin{array}{c}\text { Basement } \\
\text { Wall } \\
\text { R-Value }\end{array}$ & $\begin{array}{c}\text { Basement } \\
\text { Depth }\end{array}$ & $\begin{array}{c}\text { Slab } \\
\text { R-Value }\end{array}$ & $\begin{array}{c}\text { Slab } \\
\text { Depth }\end{array}$ \\
\hline $\begin{array}{l}5000 \text { and } \\
6000 \mathrm{HDD}\end{array}$ & 19 & 18 & 0.588 & 2.5 & 19 & 10 & 2 & 10 & 2 \\
\hline $\begin{array}{l}7000 \text { and } \\
8000 \mathrm{HDD}\end{array}$ & 24 & 18 & 0.588 & 2.5 & 19 & 10 & 4 & 10 & 2 \\
\hline $9000 \mathrm{HDD}$ & 24 & 18 & 0.588 & 2.5 & 19 & 10 & 8 & 10 & 2 \\
\hline
\end{tabular}


Table NY.8. New York State Electric Code Envelope Requirements

\begin{tabular}{||l|c|c|c|c|c|c|c|c|c||}
\hline \multicolumn{1}{|c|}{ Region } & $\begin{array}{c}\text { Ceiling } \\
\text { R-Value }\end{array}$ & $\begin{array}{c}\text { Wall } \\
\text { R-Value }\end{array}$ & $\begin{array}{c}\text { Window } \\
\text { U-Value }\end{array}$ & $\begin{array}{c}\text { Door } \\
\text { U-Value }\end{array}$ & $\begin{array}{c}\text { Floor } \\
\text { R-Value }\end{array}$ & $\begin{array}{c}\text { Basement Wall } \\
\text { R-Value }\end{array}$ & $\begin{array}{c}\text { Basement } \\
\text { Depth }\end{array}$ & $\begin{array}{c}\text { Slab } \\
\text { R-Value }\end{array}$ & $\begin{array}{c}\text { Slab } \\
\text { Depth }\end{array}$ \\
\hline $\begin{array}{l}5000 \text { and } \\
6000 \mathrm{HDD}\end{array}$ & 26 & 23 & 0.385 & 2.5 & 19 & 10 & 8 & 10 & 2 \\
\hline $\begin{array}{l}7000 \text { and } \\
8000 \mathrm{HDD}\end{array}$ & 33 & 23 & 0.385 & 2.5 & 24 & 10 & 8 & 10 & 2 \\
\hline $9000 \mathrm{HDD}$ & 33 & 23 & 0.385 & 2.5 & 24 & 10 & 8 & 10 & 2 \\
\hline
\end{tabular}

Table NY.9. 1992 MEC Envelope Requirements for New York

\begin{tabular}{||l|c|c|c|c|c|c||}
\hline & $\begin{array}{c}\text { Ceiling } \\
\text { U-Value }\end{array}$ & $\begin{array}{c}\text { Wall } \\
\text { U-Value }\end{array}$ & $\begin{array}{c}\text { Floor } \\
\text { U-Value }\end{array}$ & $\begin{array}{c}\text { Basement } \\
\text { U-Value }\end{array}$ & $\begin{array}{c}\text { Slab } \\
\text { R-Value }\end{array}$ & $\begin{array}{c}\text { Slab } \\
\text { Depth }\end{array}$ \\
\hline Albany & 0.0260 & 0.111 & 0.05 & 0.094 & 5.6 & 4 \\
\hline Batavia & 0.0260 & 0.113 & 0.05 & 0.094 & 5.5 & 4 \\
\hline Binghamton & 0.0260 & 0.110 & 0.05 & 0.093 & 5.9 & 4 \\
\hline Buffalo & 0.0260 & 0.113 & 0.05 & 0.094 & 5.5 & 4 \\
\hline Canandaigua & 0.0260 & 0.114 & 0.05 & 0.094 & 5.5 & 4 \\
\hline Cortland & 0.0260 & 0.110 & 0.05 & 0.093 & 5.9 & 4 \\
\hline Dobbs Ferry & 0.0296 & 0.137 & 0.05 & 0.098 & 4.5 & 2 \\
\hline Elmira & 0.0260 & 0.111 & 0.05 & 0.094 & 5.6 & 4 \\
\hline Fredonia & 0.0260 & 0.120 & 0.05 & 0.095 & 5.2 & 4 \\
\hline Geneva & 0.0260 & 0.112 & 0.05 & 0.094 & 5.6 & 4 \\
\hline Gloversville & 0.0260 & 0.110 & 0.05 & 0.093 & 5.9 & 4 \\
\hline Ithaca & 0.0260 & 0.110 & 0.05 & 0.093 & 5.8 & 4 \\
\hline Lockport & 0.0260 & 0.114 & 0.05 & 0.094 & 5.5 & 4 \\
\hline Massena & 0.0260 & 0.110 & 0.05 & 0.091 & 6.5 & 4 \\
\hline Mineola $\cdot$ & 0.0297 & 0.138 & 0.05 & 0.098 & 4.5 & 2 \\
\hline New York & 0.0314 & 0.143 & 0.05 & 0.099 & 4.2 & 2 \\
\hline Ogdensburg & 0.0260 & 0.110 & 0.05 & 0.092 & 6.2 & 4 \\
\hline Oswego & 0.0260 & 0.112 & 0.05 & 0.094 & 5.6 & 4 \\
\hline Patchogue & 0.0276 & 0.131 & 0.05 & 0.097 & 4.8 & 2 \\
\hline
\end{tabular}


Table NY.9. (contd)

\begin{tabular}{||l|c|c|c|c|c|c||}
\hline & $\begin{array}{c}\text { Ceiling } \\
\text { U-Value }\end{array}$ & $\begin{array}{c}\text { Wall } \\
\text { U-Value }\end{array}$ & $\begin{array}{c}\text { Floor } \\
\text { U-Value }\end{array}$ & $\begin{array}{c}\text { Basement } \\
\text { U-Value }\end{array}$ & $\begin{array}{c}\text { Slab } \\
\text { R-Value }\end{array}$ & $\begin{array}{c}\text { Slab } \\
\text { Depth }\end{array}$ \\
\hline Poughkeepsie & 0.0260 & 0.120 & 0.05 & 0.095 & 5.2 & 4 \\
\hline Rochester & 0.0260 & 0.114 & 0.05 & 0.095 & 5.5 & 4 \\
\hline Rome & 0.0260 & 0.110 & 0.05 & 0.093 & 5.9 & 4 \\
\hline Scarsdale & 0.0288 & 0.135 & 0.05 & 0.098 & 4.6 & 2 \\
\hline Schenectady & 0.0260 & 0.111 & 0.05 & 0.094 & 5.6 & 4 \\
\hline Syracuse & 0.0260 & 0.113 & 0.05 & 0.094 & 5.5 & 4 \\
\hline Utica & 0.0260 & 0.110 & 0.05 & 0.093 & 5.9 & 4 \\
\hline Watertown & 0.0260 & 0.110 & 0.05 & 0.093 & 6.0 & 4 \\
\hline
\end{tabular}

Table NY.10 shows the design information and housing starts for each of the cities used in the analysis.

Table NY.10. Design Information and Housing Starts for New York

\begin{tabular}{||l|c|c|c|c||}
\hline & HDD & $\begin{array}{c}\text { Design } \\
\text { Temperature }\end{array}$ & $\begin{array}{c}\text { Housing } \\
\text { Starts }\end{array}$ & Region \\
\hline Albany & 6,929 & -1 & 1,827 & 2 \\
\hline Batavia & 6,810 & 5 & 136 & 2 \\
\hline Binghamton & 7,346 & 1 & 286 & 2 \\
\hline Buffalo & 6,799 & 6 & 3,300 & 2 \\
\hline Canandaigua & 6,747 & 7 & 285 & 2 \\
\hline Cortland & 7,357 & 0 & 0 & 2 \\
\hline Dobbs Ferry & 5,242 & 9 & 1,118 & 1 \\
\hline Elmira & 6,931 & 1 & 0 & 2 \\
\hline Fredonia & 6,344 & -3 & 72 & 2 \\
\hline Geneva & 6,885 & 2 & 0 & 2 \\
\hline Gloversville & 7,305 & -2 & 318 & 2 \\
\hline Ithaca & 7,182 & 0 & 0 & 2 \\
\hline
\end{tabular}


Table NY.10. (contd)

\begin{tabular}{||l|c|c|c|c||}
\hline & HDD & $\begin{array}{c}\text { Design } \\
\text { Temperature }\end{array}$ & $\begin{array}{c}\text { Housing } \\
\text { Starts }\end{array}$ & Region \\
\hline Lockport & 6,753 & 7 & 728 & 2 \\
\hline Massena & 8,184 & -8 & 73 & 2 \\
\hline Mineola & 5,230 & 5 & 572 & 1 \\
\hline New York & 4,869 & 15 & 5,939 & 1 \\
\hline Ogdensburg & 7,832 & -4 & 0 & 2 \\
\hline Oswego & 6,845 & 4 & 187 & 2 \\
\hline Patchogue & 5,670 & 4 & 4,135 & 1 \\
\hline Poughkeepsie & 6,368 & 6 & 1,492 & 2 \\
\hline Rochester & 6,718 & 5 & 3,909 & 2 \\
\hline Rome & 7,372 & -5 & 23 & 2 \\
\hline Scarsdale & 5,420 & 7 & 1,216 & 1 \\
\hline Schenectady & 6,929 & 1 & 1,470 & 2 \\
\hline Syracuse & 6,789 & 2 & 1,733 & 2 \\
\hline Utica & 7,372 & -6 & 96 & 2 \\
\hline Watertown & 7,484 & -6 & 75 & 2 \\
\hline \hline
\end{tabular}




\section{North Carolina}

The North Carolina State Building Code is the mandatory state building code for North Carolina. The 1995 revisions to the North Carolina code, effective January 1, 1995, give a single set of prescriptive overall R-value thermal envelope requirements. The overall $\mathrm{R}$-value is not an insulation $\mathrm{R}$-value, but an overall R-value for the envelope component through the cavity section.

An overall envelope U-value comparison was performed. Concrete walls with a weight greater than or equal to $30 \mathrm{psf}$ have less stringent requirements than other exterior walls. The concrete wall requirements differ depending on whether the insulation is placed on the interior or exterior of the wall. Concrete basement walls with interior insulation is assumed to be the most commonly used insulated basement configuration and has been assumed for the $U$-value comparison. The window requirement for homes with less than $23 \%$ window-to-floor area is double-pane windows or single-pane windows with a storm window. For this analysis, windows were assumed to be double pane with a $U$-value of 0.72 .

Table NC. 1 shows the overall envelope U-value for the state code and the 1992 MEC (CABO 1992). The average overall state code U-value is higher than the average overall MEC U-value. Therefore, the North Carolina code marginally does not meet the 1992 MEC requirements for one- and two-family dwellings.

Table NC.1. Average Overall Envelope U-Value for North Carolina

\begin{tabular}{|l|l|}
\hline & \multicolumn{1}{|c|}{$\mathrm{U}_{\mathrm{o}}$} \\
\hline State Average & $0.097(4 \%$ above MEC avg.) \\
\hline MEC Average & 0.094 \\
\hline
\end{tabular}

Tables NC.2 and NC.3 show a more detailed comparison of the state code to the 1992 MEC by the type of foundation insulation used and by envelope component. Table NC. 2 also shows combined Uvalues, which are the average overall envelope $U$-values based on foundation type, averaged and weighted by the proportion of homes in the state with the given foundation type (percentages shown in parentheses). Table NC.3 shows the state average U-value for walls, ceilings, and floors over unheated spaces and the state average F-value for slab and basement walls. 
Table NC.2. Average Overall Envelope U-Values by Foundation Type for North Carolina

\begin{tabular}{|l|c|c|c|c|}
\hline \hline & Slab (14\%) & $\begin{array}{c}\text { Floor Over } \\
\text { Unheated Space } \\
(79 \%)\end{array}$ & $\begin{array}{c}\text { Basement Wall } \\
(8 \%)\end{array}$ & Combined \\
\hline State Average & 0.107 & 0.095 & 0.093 & 0.097 \\
\hline MEC Average & 0.101 & 0.091 & 0.095 & 0.094 \\
\hline
\end{tabular}

Table NC.3. Average Envelope Component U-Values or F-Values for North Carolina

\begin{tabular}{|l|c|c|c|c|c||}
\hline & $\begin{array}{c}\text { Wall } \\
\left(\mathrm{Btu} / \mathrm{h} \bullet{ }^{\circ} \mathrm{F} \bullet \mathrm{ft}^{2}\right)\end{array}$ & $\begin{array}{c}\text { Ceiling } \\
\left(\mathrm{Btu} / \mathrm{h} \bullet{ }^{\circ} \mathrm{F} \bullet \mathrm{ft}^{2}\right)\end{array}$ & $\begin{array}{c}\text { Floor } \\
\left(\mathrm{Btu} / \mathrm{h} \bullet{ }^{\circ} \mathrm{F} \bullet \mathrm{ft}^{2}\right)\end{array}$ & $\begin{array}{c}\text { Slab } \\
\left(\mathrm{Btu} / \mathrm{h} \bullet \mathrm{ft} \bullet{ }^{\circ} \mathrm{F}\right)\end{array}$ & $\begin{array}{c}\text { Basement } \\
\left(\mathrm{Btu} / \mathrm{h} \bullet \mathrm{ft}{ }^{\circ} \mathrm{F}\right)\end{array}$ \\
\hline State Average & 0.181 & 0.035 & 0.047 & 0.804 & 1.148 \\
\hline MEC Average & 0.166 & 0.038 & 0.051 & 0.779 & 1.345 \\
\hline (a) Includes windows and doors. \\
\hline
\end{tabular}

The results of the duct analysis showed duct losses associated with the North Carolina code requirements to be $6.1 \%$ compared to duct losses of $3.4 \%$ associated with the $1992 \mathrm{MEC}$ requirements.

Tables NC.4 and NC.5 show the envelope requirements for the state code and for the 1992 MEC.

Table NC.4. North Carolina State Code Envelope Requirements

\begin{tabular}{||l|c|}
\hline Ceiling R-Value & 30 \\
\hline Opaque Wall U-Value & 0.0727 \\
\hline Window U-Value & 0.72 \\
\hline Door R-Value & 1.66 \\
\hline Floor R-Value & 19 \\
\hline Basement Wall R-Value & 11 \\
\hline Basement Depth & 8 \\
\hline Slab R-Value & 5 \\
\hline Slab Depth & 2 \\
\hline
\end{tabular}


Table NC.5. 1992 MEC Envelope Requirements for North Carolina

\begin{tabular}{|l|c|c|c|c|c|c||}
\hline & $\begin{array}{c}\text { Ceiling } \\
\text { U-Value }\end{array}$ & $\begin{array}{c}\text { Wall } \\
\text { U-Value }\end{array}$ & $\begin{array}{c}\text { Floor } \\
\text { U-Value }\end{array}$ & $\begin{array}{c}\text { Basement } \\
\text { U-Value }\end{array}$ & $\begin{array}{c}\text { Slab } \\
\text { R-Value }\end{array}$ & $\begin{array}{c}\text { Slab } \\
\text { Depth }\end{array}$ \\
\hline Albemarle & 0.0389 & 0.167 & 0.05 & 0.128 & 4 & 2 \\
\hline Asheboro & 0.0390 & 0.168 & 0.05 & 0.128 & 4 & 2 \\
\hline Asheville & 0.0342 & 0.152 & 0.05 & 0.105 & 4 & 2 \\
\hline Boone & 0.0285 & 0.134 & 0.05 & 0.098 & 4.7 & 2 \\
\hline Burlington & 0.0378 & 0.164 & 0.05 & 0.122 & 4 & 2 \\
\hline Chapel Hill & 0.0369 & 0.161 & 0.05 & 0.118 & 4 & 2 \\
\hline Charlotte & 0.0387 & 0.167 & 0.05 & 0.127 & 4 & 2 \\
\hline Concord & 0.0383 & 0.165 & 0.05 & 0.125 & 4 & 2 \\
\hline Durham & 0.0374 & 0.163 & 0.05 & 0.121 & 4 & 2 \\
\hline Elizabeth City & 0.0392 & 0.168 & 0.05 & 0.129 & 4 & 2 \\
\hline Fayetteville & 0.0396 & 0.170 & 0.05 & 0.131 & 4 & 2 \\
\hline Gastonia & 0.0396 & 0.170 & 0.05 & 0.131 & 4 & 2 \\
\hline Goldsboro & 0.0399 & 0.171 & 0.05 & 0.132 & 4 & 2 \\
\hline Greensboro & 0.0362 & 0.159 & 0.05 & 0.115 & 4 & 2 \\
\hline Hickory & 0.0368 & 0.160 & 0.05 & 0.117 & 4 & 2 \\
\hline High Point & 0.0383 & 0.166 & 0.05 & 0.125 & 4 & 2 \\
\hline Kinston & 0.0397 & 0.170 & 0.05 & 0.132 & 4 & 2 \\
\hline Laurinburg & 0.0419 & 0.177 & 0.05 & 0.143 & 4 & 2 \\
\hline Lenoir & 0.0372 & 0.162 & 0.05 & 0.120 & 4 & 2 \\
\hline Lexington & 0.0392 & 0.168 & 0.05 & 0.129 & 4 & 2 \\
\hline Lumberton & 0.0402 & 0.172 & 0.05 & 0.134 & 4 & 2 \\
\hline Monroe & 0.0398 & 0.170 & 0.05 & 0.132 & 4 & 2 \\
\hline Morganton & 0.0374 & 0.162 & 0.05 & 0.120 & 4 & 2 \\
\hline New Bern & 0.0415 & 0.176 & 0.05 & 0.141 & 4 & 2 \\
\hline
\end{tabular}


Table NC.5. (contd)

\begin{tabular}{||l|c|c|c|c|c|c||}
\hline & $\begin{array}{c}\text { Ceiling } \\
\text { U-Value }\end{array}$ & $\begin{array}{c}\text { Wall } \\
\text { U-Value }\end{array}$ & $\begin{array}{c}\text { Floor } \\
\text { U-Value }\end{array}$ & $\begin{array}{c}\text { Basement } \\
\text { U-Value }\end{array}$ & $\begin{array}{c}\text { Slab } \\
\text { R-Value }\end{array}$ & $\begin{array}{c}\text { Slab } \\
\text { Depth }\end{array}$ \\
\hline Raleigh & 0.0378 & 0.164 & 0.05 & 0.122 & 4 & 2 \\
\hline Reidsville & 0.0363 & 0.159 & 0.05 & 0.115 & 4 & 2 \\
\hline Rocky Mount & 0.0393 & 0.169 & 0.05 & 0.130 & 4 & 2 \\
\hline Salisbury & 0.0384 & 0.166 & 0.05 & 0.125 & 4 & 2 \\
\hline Shelby & 0.0373 & 0.162 & 0.05 & 0.120 & 4 & 2 \\
\hline Statesville & 0.0366 & 0.160 & 0.05 & 0.116 & 4 & 2 \\
\hline Wilmington & 0.0429 & 0.181 & 0.07 & 0.147 & 0 & - \\
\hline Wilson & 0.0392 & 0.169 & 0.05 & 0.129 & 4 & 2 \\
\hline Winston-Salem & 0.0383 & 0.166 & 0.05 & 0.125 & 4 & 2 \\
\hline \hline
\end{tabular}

Table NC. 6 shows the design information and housing starts for each of the cities used in the analysis.

Table NC.6. Design Information and Housing Starts for North Carolina

\begin{tabular}{||l|c|c|c||}
\hline \hline & HDD & $\begin{array}{c}\text { Design } \\
\text { Temperature }\end{array}$ & $\begin{array}{c}\text { Housing } \\
\text { Starts }\end{array}$ \\
\hline Albemarle & 3,321 & 19 & 272 \\
\hline Asheboro & 3,302 & 17 & 376 \\
\hline Asheville & 4,300 & 14 & 3,486 \\
\hline Boone & 5,480 & 2 & 654 \\
\hline Burlington & 3,544 & 16 & 619 \\
\hline Chapel Hill & 3,730 & 14 & 665 \\
\hline Charlotte & 3,348 & 22 & 6,232 \\
\hline Concord & 3,445 & 15 & 949 \\
\hline Durham & 3,615 & 20 & 2,077 \\
\hline Elizabeth City & 3,252 & 19 & 631 \\
\hline
\end{tabular}

A. 87 
Table NC.6. (contd)

\begin{tabular}{||l|c|c|c||}
\hline & HDD & $\begin{array}{c}\text { Design } \\
\text { Temperature }\end{array}$ & $\begin{array}{c}\text { Housing } \\
\text { Starts }\end{array}$ \\
\hline Fayetteville & 3,161 & 20 & 3,709 \\
\hline Gastonia & 3,166 & 32 & 963 \\
\hline Goldsboro & 3,112 & 21 & 145 \\
\hline Greensboro & 3,877 & 18 & 2,700 \\
\hline Hickory & 3,757 & 18 & 863 \\
\hline High Point & 3,428 & 20 & 573 \\
\hline Kinston & 3,137 & 28 & 242 \\
\hline Laurinburg & 2,678 & 31 & 377 \\
\hline Lenoir & 3,663 & 18 & 400 \\
\hline Lexington & 3,245 & 20 & 1,338 \\
\hline Lumberton & 3,049 & 21 & 373 \\
\hline Monroe & 3,121 & 20 & 1,589 \\
\hline Morganton & 3,632 & 13 & 251 \\
\hline New Bern & 2,765 & 24 & 2,149 \\
\hline Raleigh & 3,538 & 15 & 7,717 \\
\hline Reidsville & 3,848 & 10 & 0 \\
\hline Rocky Mount & 3,220 & 21 & 737 \\
\hline Salibury & 3,424 & 19 & 747 \\
\hline Shelby & 3,649 & 16 & 1,111 \\
\hline Statesville & 3,800 & 13 & 842 \\
\hline Wilmington & 2,473 & 26 & 2,601 \\
\hline Wilson & 3,241 & 16 & 2,027 \\
\hline Winston-Salem & 3,428 & 20 & 2,022 \\
\hline
\end{tabular}




\section{North Dakota}

The North Dakota Energy Conservation Standards is the state energy code for North Dakota. Local governments are not required to adopt and enforce the state energy code, but they are not allowed to adopt a different energy code. The North Dakota code references the $1989 \mathrm{MEC}$ (CABO 1989). Therefore, the North Dakota code meets the 1992 MEC (CABO 1992) requirements for one- and two-family and dwellings. 


\section{Ohio}

The Ohio Basic Building Code is the state building code. The Ohio code adopts and amends the provisions of the 1993 BOCA National Building Code for one- and two-family dwellings, adding another path for compliance. The BOCA National Building Code allows for compliance using ANSIIASHRAEIIES Standard 90A-1980 (ASHRAE 1980) or the 1989 MEC (CABO 1989). ANSI/ASHRAE/IES Standard 90A-1980 is less stringent than the 1992 MEC (CABO 1992) (see Section 2.3 of this report). Therefore, Ohio does not meet the 1992 MEC requirements for one- and two-family dwellings. 


\section{Oklahoma}

Oklahoma has not adopted a state residential energy code. Therefore, Oklahoma does not meet the 1992 MEC (CABO 1992) requirements for one- and two-family dwellings. 


\section{Oregon}

The 1992 Oregon Residential Energy Code is the mandatory state energy code for new residential construction. Several prescriptive paths are given for compliance. Path 1 was used for this analysis and was assumed to result in approximately the same energy consumption as the other paths. Path one was chosen because it is the "cost-effective" path and the path upon which the other paths are based. An overall envelope U-value comparison was performed.

Table OR.1 shows the average overall envelope U-value for the state code and the $1992 \mathrm{MEC}$ (CABO 1992). The average overall state code U-value is lower than the average overall MEC U-value. Therefore, the Oregon code meets the $1992 \mathrm{MEC}$ requirements for one- and two-family dwellings.

Table OR.1. Average Overall Envelope U-Value for Oregon

\begin{tabular}{||c|c|}
\hline & $\mathrm{U}_{\mathrm{o}}$ \\
\hline State Average & $\begin{array}{c}0.061 \\
(23 \% \text { below MEC avg. })\end{array}$ \\
\hline MEC Average & 0.08 \\
\hline
\end{tabular}

Tables OR.2 and OR.3 show a more detailed comparison of the state code to the 1992 MEC by the type of foundation insulation used and by envelope component. Table OR.2 also shows combined Uvalues, which are the average overall envelope $U$-values based on foundation type, averaged and weighted by the proportion of homes in the state with the given foundation type (percentages shown in parentheses). Table OR.3 shows the state average U-value for walls, ceilings, and floors over unheated spaces and the state average F-value for slab and basement walls.

Table OR.2. Average Overall Envelope U-Values by Foundation Type for Oregon

\begin{tabular}{||l|c|c|c|c||}
\hline & Slab (3\%) & $\begin{array}{c}\text { Floor Over Unheated } \\
\text { Space (86\%) }\end{array}$ & $\begin{array}{c}\text { Basement } \\
\text { Wall (11\%) }\end{array}$ & Combined \\
\hline State Average & 0.071 & 0.061 & 0.065 & 0.061 \\
\hline MEC Average & 0.089 & 0.079 & 0.083 & 0.080 \\
\hline
\end{tabular}


Table OR.3. Average Envelope Component U-Values or F-Values for Oregon

\begin{tabular}{|c|c|c|c|c|c|}
\hline & $\begin{array}{c}\text { Ceiling } \\
\left(\mathrm{Btu} / \mathrm{h} \bullet \mathrm{ft}^{2} \bullet^{\circ} \mathrm{F}\right)\end{array}$ & $\begin{array}{c}\text { Wall } \\
\left(\mathrm{Btu} / \mathrm{h} \cdot \mathrm{ft}^{2} \bullet^{\circ} \mathrm{F}\right)\end{array}$ & $\begin{array}{c}\text { Slab } \\
\left(\mathrm{Btu} / \mathrm{h} \cdot \mathrm{ft} \bullet^{\circ} \mathrm{F}\right)\end{array}$ & 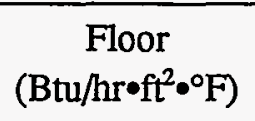 & $\begin{array}{c}\text { Basement } \\
\left(\mathrm{Btu} / \mathrm{hr} \bullet \mathrm{ft} \bullet^{\circ} \mathrm{F}\right)\end{array}$ \\
\hline State Average & 0.030 & 0.104 & 0.655 & 0.038 & 0.996 \\
\hline MEC Average & 0.031 & 0.141 & 0.768 & 0.050 & 1.239 \\
\hline
\end{tabular}

The results of the duct analysis showed duct losses associated with the Oregon code requirements to be $2.7 \%$ compared to duct losses of $3 \%$ associated with the 1992 MEC requirements.

Tables OR.4 and OR.5 show the envelope requirements for the state code and for the 1992 MEC.

Table OR.4. Oregon State Code Envelope Requirements

\begin{tabular}{||l|c||}
\hline Ceiling R-Value & 38 \\
\hline Wall R-Value & 21 \\
\hline Window U-Value & 0.40 \\
\hline Door U-Value & 0.20 \\
\hline Floor R-Value & 25 \\
\hline Basement Wall R-Value & 21 \\
\hline Basement Depth & 8 \\
\hline Slab R-Value & 15 \\
\hline Slab Depth & 4 \\
\hline
\end{tabular}


Table OR.5. 1992 MEC Envelope Requirements for Oregon

\begin{tabular}{|l|c|c|c|c|c|c||}
\hline & $\begin{array}{c}\text { Ceiling } \\
\text { U-Value }\end{array}$ & $\begin{array}{c}\text { Wall } \\
\text { U-Value }\end{array}$ & $\begin{array}{c}\text { Floor } \\
\text { U-Value }\end{array}$ & $\begin{array}{c}\text { Basement } \\
\text { U-Value }\end{array}$ & $\begin{array}{c}\text { Slab } \\
\text { R-Value }\end{array}$ & $\begin{array}{c}\text { Slab } \\
\text { Depth }\end{array}$ \\
\hline Ashland & 0.0301 & 0.139 & 0.05 & 0.098 & 4.4 & 2 \\
\hline Bend & 0.0260 & 0.110 & 0.05 & 0.094 & 5.7 & 4 \\
\hline Corvallis & 0.0308 & 0.141 & 0.05 & 0.099 & 4.3 & 2 \\
\hline Eugene & 0.0317 & 0.144 & 0.05 & 0.099 & 4.2 & 2 \\
\hline Forest Grove & 0.0316 & 0.144 & 0.05 & 0.099 & 4.2 & 2 \\
\hline Grants Pass & 0.0340 & 0.152 & 0.05 & 0.104 & 4.0 & 2 \\
\hline Klamath Falls & 0.0260 & 0.117 & 0.05 & 0.095 & 5.4 & 4 \\
\hline Lagrande & 0.0260 & 0.125 & 0.05 & 0.096 & 5.0 & 4 \\
\hline Mcminnville & 0.0309 & 0.141 & 0.05 & 0.099 & 4.3 & 2 \\
\hline Medford & 0.0317 & 0.144 & 0.05 & 0.099 & 4.2 & 2 \\
\hline Oregon City & 0.0336 & 0.150 & 0.05 & 0.102 & 4.0 & 2 \\
\hline Pendleton & 0.0295 & 0.137 & 0.05 & 0.098 & 4.5 & 2 \\
\hline Portland & 0.0323 & 0.146 & 0.05 & 0.100 & 4.1 & 2 \\
\hline Roseburg & 0.0334 & 0.150 & 0.05 & 0.101 & 4.0 & 2 \\
\hline Salem & 0.0309 & 0.142 & 0.05 & 0.099 & 4.3 & 2 \\
\hline
\end{tabular}

Table OR.6 shows the design information and housing starts for each of the cities used in the analysis. 
Table OR.6. Design Information and Housing Starts for Oregon

\begin{tabular}{|l|c|c|c||}
\hline & HDD & $\begin{array}{c}\text { Design } \\
\text { Temperature }\end{array}$ & $\begin{array}{c}\text { Housing } \\
\text { Starts }\end{array}$ \\
\hline Ashland & 5,145 & 18 & 1,117 \\
\hline Bend & 7,082 & 4 & 1,448 \\
\hline Corvallis & 4,990 & 22 & 761 \\
\hline Eugene & 4,803 & 22 & 1,339 \\
\hline Forest Grove & 4,828 & 10 & 3,450 \\
\hline Grants Pass & 4,329 & 24 & 690 \\
\hline Klamath Falls & 6,583 & 9 & 123 \\
\hline Lagrande & 6,059 & 6 & 64 \\
\hline Mcminnville & 4,981 & 21 & 780 \\
\hline Medford & 4,803 & 23 & 0 \\
\hline Oregon City & 4,417 & 16 & 2,128 \\
\hline Pendleton & 5,275 & 5 & 374 \\
\hline Portland & 4,693 & 23 & 2,795 \\
\hline Roseburg & 4,454 & 23 & 362 \\
\hline Salem & 4,978 & 23 & 1,901 \\
\hline
\end{tabular}




\section{Pennsylvania}

The Pennsylvania Residential Energy Code is mandatory for new residential construction. The code has a single set of prescriptive total R-value thermal envelope requirements. An overall envelope U-value comparison was performed.

The $\mathrm{R}$-value requirements in the state code are total envelope component $\mathrm{R}$-values and do not include framing. For the analysis, these $\mathrm{R}$-values were adjusted to represent the whole component $U$-value, including framing using the U-value calculation method described in the ASHRAE 1993 Fundamentals Handbook (ASHRAE 1993).

Table PA. 1 shows the average overall envelope U-value for the state code and the $1992 \mathrm{MEC}$ (CABO 1992). The average overall state code $U$-value is higher than the average overall MEC U-value. Therefore, the Pennsylvania code does not meet the 1992 MEC requirements for one- and two-family dwellings.

Table PA.1. Average Overall Envelope U-Value for Pennsylvania

\begin{tabular}{||c|c|}
\hline & $\mathrm{U}_{\mathrm{o}}$ \\
\hline State Average & $\begin{array}{c}0.097 \\
\text { (29\% above MEC avg.) }\end{array}$ \\
\hline MEC Average & 0.076 \\
\hline
\end{tabular}

Tables PA. 2 and PA.3 show a more detailed comparison of the state code to the $1992 \mathrm{MEC}$ by the type of foundation insulation used and by envelope component. Table PA.2 also shows combined Uvalues, which are the average overall envelope $U$-values based on foundation type, averaged and weighted by the proportion of homes in the state with the given foundation type (percentages shown in parentheses). Table PA.3 shows the state average U-value for walls, ceilings, and floors over unheated spaces and the state average F-value for slab and basement walls.

Table PA.2. Overall Envelope U-Values by Foundation Type for Pennsylvania

\begin{tabular}{|l|c|c|c|c|}
\hline \hline & Slab (4\%) & $\begin{array}{c}\text { Floor Over Unheated } \\
\text { Space (94\%) }\end{array}$ & $\begin{array}{c}\text { Basement } \\
\text { Wall (2\%) }\end{array}$ & Combined \\
\hline State Average & 0.096 & 0.098 & 0.085 & 0.097 \\
\hline MEC Average & 0.085 & 0.075 & 0.079 & 0.076 \\
\hline
\end{tabular}


Table PA.3. Average Envelope Component U-Values or F-Values for Pennsylvania

\begin{tabular}{|l|c|c|c|c|c|}
\hline & $\begin{array}{c}\text { Ceiling } \\
\left(\mathrm{Btu} / \mathrm{h} \bullet \mathrm{ft}^{2} \bullet \circ \mathrm{F}\right)\end{array}$ & $\begin{array}{c}\text { Wall }^{(\mathrm{a})} \\
\left(\mathrm{Btu} / \mathrm{h} \bullet \mathrm{ft}^{2} \bullet \circ \mathrm{F}\right)\end{array}$ & $\begin{array}{c}\text { Slab } \\
\left(\mathrm{Btu} / \mathrm{h} \bullet \mathrm{ft} \bullet^{\circ} \mathrm{F}\right)\end{array}$ & $\begin{array}{c}\text { Floor } \\
\left(\mathrm{Btu} / \mathrm{h} \bullet \mathrm{ft}^{2} \bullet{ }^{\circ} \mathrm{F}\right)\end{array}$ & $\begin{array}{c}\text { Basement } \\
\left(\mathrm{Btu} / \mathrm{h} \bullet \mathrm{ft} \bullet{ }^{\circ} \mathrm{F}\right)\end{array}$ \\
\hline State Average & 0.034 & 0.153 & 0.794 & 0.094 & 1.182 \\
\hline MEC Average & 0.028 & 0.133 & 0.771 & 0.050 & 1.232 \\
\hline (a) Includes windows and doors. \\
\hline
\end{tabular}

Tables PA.4 and PA.5 show the envelope requirements for the state code and for the MEC.

Table PA.4. Pennsylvania State Code Envelope Requirements

\begin{tabular}{||l|c|}
\hline Ceiling.U-Value & 0.0342 \\
\hline Wall U-Value & 0.0680 \\
\hline Window U-Value & 0.6250 \\
\hline Door U-Value & 0.2500 \\
\hline Floor U-Value & 0.0937 \\
\hline Basement Wall R-Value & 10 \\
\hline Basement Depth & 8 \\
\hline Slab R-Value & 6 \\
\hline Slab Depth & 2 \\
\hline
\end{tabular}


Table PA.5. 1992 MEC Envelope Requirements for Pennsylvania

\begin{tabular}{||l|c|c|c|c|c|c||}
\hline & $\begin{array}{c}\text { Ceiling } \\
\text { U-Value }\end{array}$ & $\begin{array}{c}\text { Wall } \\
\text { U-Value }\end{array}$ & $\begin{array}{c}\text { Floor } \\
\text { U-Value }\end{array}$ & $\begin{array}{c}\text { Basement } \\
\text { U-Value }\end{array}$ & $\begin{array}{c}\text { Slab } \\
\text { R-Value }\end{array}$ & $\begin{array}{c}\text { Slab } \\
\text { Depth }\end{array}$ \\
\hline Allentown & 0.0269 & 0.128 & 0.05 & 0.097 & 4.9 & 2 \\
\hline Bradford & 0.0260 & 0.110 & 0.05 & 0.091 & 6.3 & 4 \\
\hline Carlisle & 0.0292 & 0.136 & 0.05 & 0.098 & 4.5 & 2 \\
\hline Chambersburg & 0.0279 & 0.132 & 0.05 & 0.097 & 4.7 & 2 \\
\hline Coatesville & 0.0278 & 0.131 & 0.05 & 0.097 & 4.8 & 2 \\
\hline Erie & 0.0260 & 0.114 & 0.05 & 0.094 & 5.5 & 4 \\
\hline Hanover & 0.0292 & 0.136 & 0.05 & 0.098 & 4.6 & 2 \\
\hline Harrisburg & 0.0292 & 0.136 & 0.05 & 0.098 & 4.6 & 2 \\
\hline Indiana & 0.0260 & 0.123 & 0.05 & 0.096 & 5.1 & 4 \\
\hline Johnstown & 0.0271 & 0.129 & 0.05 & 0.097 & 4.9 & 2 \\
\hline Lancaster & 0.0292 & 0.136 & 0.05 & 0.098 & 4.6 & 2 \\
\hline Meadville & 0.0260 & 0.112 & 0.05 & 0.094 & 5.6 & 4 \\
\hline New Castle & 0.0265 & 0.127 & 0.05 & 0.097 & 4.9 & 2 \\
\hline Philadelphia & 0.0310 & 0.142 & 0.05 & 0.099 & 4.3 & 2 \\
\hline Phoenixville & 0.0298 & 0.138 & 0.05 & 0.098 & 4.5 & 2 \\
\hline Pittisburgh & 0.0262 & 0.126 & 0.05 & 0.096 & 5.0 & 4 \\
\hline Reading & 0.0298 & 0.138 & 0.05 & 0.098 & 4.5 & 2 \\
\hline Scranton & 0.0260 & 0.120 & 0.05 & 0.095 & 5.2 & 4 \\
\hline Uniontown & 0.0289 & 0.135 & 0.05 & 0.098 & 4.6 & 2 \\
\hline Warren & 0.0260 & 0.116 & 0.05 & 0.095 & 5.4 & 4 \\
\hline West Chester & 0.0290 & 0.135 & 0.05 & 0.098 & 4.6 & 2 \\
\hline Wilkes-Barre & 0.0260 & 0.120 & 0.05 & 0.095 & 5.2 & 4 \\
\hline Williamsport & 0.0260 & 0.125 & 0.05 & 0.096 & 5.0 & 4 \\
\hline York & 0.0298 & 0.138 & 0.05 & 0.098 & 4.5 & 2 \\
\hline \hline
\end{tabular}

Table PA.6 shows the design information and housing starts for each of the cities used in the analysis. 
Table PA.6. Design Information and Housing Starts for Pennsylvania

\begin{tabular}{|l|c|c|c||}
\hline & HDD & $\begin{array}{c}\text { Design } \\
\text { Temperature }\end{array}$ & $\begin{array}{c}\text { Housing } \\
\text { Starts }\end{array}$ \\
\hline Allentown & 5,815 & 9 & 3,143 \\
\hline Bradford & 7,956 & -7 & 0 \\
\hline Carlisle & 5,323 & 4 & 1,349 \\
\hline Chambersburg & 5,600 & 8 & 1,397 \\
\hline Coatesville & 5,633 & 11 & 0 \\
\hline Erie & 6,768 & 9 & 818 \\
\hline Hanover & 5,339 & 8 & 961 \\
\hline Harrisburg & 5,339 & 11 & 1,735 \\
\hline Indiana & 6,164 & -1 & 490 \\
\hline Johnstown & 5,772 & 2 & 314 \\
\hline Lancaster & 5,339 & 8 & 2,419 \\
\hline Meadville & 6,883 & 4 & 0 \\
\hline New Castle & 5,892 & 7 & 1,122 \\
\hline Philadelphia & 4,954 & 14 & 8,916 \\
\hline Phoenixville & 5,198 & 13 & 0 \\
\hline Pittsburgh & 5,957 & 5 & 4,937 \\
\hline Reading & 5,198 & 13 & 1,303 \\
\hline Scranton & 6,332 & 5 & 1,951 \\
\hline Uniontown & 5,393 & 9 & 91 \\
\hline Warren & 6,634 & 4 & 175 \\
\hline West Chester & 5,375 & 13 & 2,116 \\
\hline Wilkes-Barre & 6,332 & 5 & 2,352 \\
\hline Williamsport & 6,053 & 7 & 316 \\
\hline York & 5,207 & 12 & 3,252 \\
\hline \hline
\end{tabular}




\section{Rhode Island}

The Rhode Island State Building Code is the state building code for Rhode Island. The energy portion of the Rhode Island code gives separate requirements for electric and nonelectric homes. An overall envelope U-value comparison was performed for both categories.

The state code is unclear in its requirements for basement walls when the basement is conditioned. Note 3 in Table B in the state code relating to floors requires foundation wall insulation with an R-value of $\mathrm{R}-11$ for a depth of $4 \mathrm{ft}$ when insulation is omitted from floors over unheated areas. This requirement seems to apply only when the basement area is unconditioned. Basement wall insulation requirements are not specifically addressed for conditioned basements. The wall requirements are applicable for "all wall description containing heated or mechanically cooled space." It is not clear if "all wall description" includes foundation walls. The 1990 BOCA National Building Code (Section 310.2.1.3) (BOCA 1990a) definition of an exterior wall, for thermal envelope requirement purposes, does not include below-grade foundation walls. Because the basement wall requirements were unclear, the building inspector in Providence was contacted for his interpretation of the state code. The building department in Providence interprets the state code to require R-11 insulation for a depth of $4 \mathrm{ft}$ for unconditioned basement walls when there is no floor insulation and for conditioned basements. For the U-value comparison, the basement wall insulation requirements will be assumed to be $R-11$ for a depth of $4 \mathrm{ft}$.

Table RI. 1 shows the average overall envelope U-values for the state code and the 1992 MEC (CABO 1992) for electric and nonelectric homes. The average overall U-value for the state nonelectric code is higher than the overall MEC U-value. Therefore, the Rhode Island nonelectric code does not meet the 1992 MEC requirements for one- and two-family dwellings. The average overall U-value for the state electric code is slightly higher than the overall MEC U-value. Therefore, the Rhode Island electric code marginally does not meet the $1992 \mathrm{MEC}$ requirements for one- and two-family dwellings.

Table RI.1. Average Overall Envelope U-Values for Rhode Island

\begin{tabular}{|l|c||}
\hline & $\mathrm{U}_{\mathrm{o}}$ \\
\hline State Average (Nonelectric) & $\begin{array}{c}0.098 \\
(31 \% \text { above MEC avg.) }\end{array}$ \\
\hline State Average (Electric) & $\begin{array}{c}0.077 \\
(3 \% \text { above MEC avg.) }\end{array}$ \\
\hline MEC Average & 0.075 \\
\hline
\end{tabular}


Tables RI. 2 and RI.3 show a more detailed comparison of the state code to the 1992 MEC by the type of foundation insulation used and by envelope component. Table RI.2 also shows combined U-values, which are the overall envelope U-values based on foundation type, averaged and weighted by the proportion of homes in the state with the given foundation type (percentages shown in parentheses). Table RI.3 shows the state average U-value for walls, ceilings, and floors over unheated spaces and the state average $F$-value for slab and basement walls.

Table RI.2. Average Overall Envelope U-Values by Foundation Type for Rhode Island

\begin{tabular}{||l|c|c|c|c|}
\hline & Slab (2\%) & $\begin{array}{c}\text { Floor Over Unheated } \\
\text { Space (51\%) }\end{array}$ & $\begin{array}{c}\text { Basement } \\
\text { Wall (47\%) }\end{array}$ & Combined \\
\hline State Average (Nonelectric) & 0.104 & 0.094 & 0.102 & 0.098 \\
\hline State Average (Electric) & 0.081 & 0.071 & 0.084 & 0.077 \\
\hline MEC Average & 0.082 & 0.072 & 0.077 & 0.075 \\
\hline
\end{tabular}

Table RI.3. Average Envelope Component U-Values or F-Values for Rhode Island

\begin{tabular}{||l|c|c|c|c|c||}
\hline & $\begin{array}{c}\text { Ceiling } \\
\left(\mathrm{Btu} / \mathrm{h} \bullet \mathrm{ft}^{2} \bullet^{\circ} \mathrm{F}\right)\end{array}$ & $\begin{array}{c}\mathrm{Wall}^{(\mathrm{a})} \\
\left(\mathrm{Btu} / \mathrm{h} \cdot \mathrm{ft}^{2} \bullet{ }^{\circ} \mathrm{F}\right)\end{array}$ & $\begin{array}{c}\text { Slab } \\
\left(\mathrm{Btu} / \mathrm{h} \bullet \mathrm{ft} \bullet{ }^{\circ} \mathrm{F}\right)\end{array}$ & $\begin{array}{c}\text { Floor } \\
\left(\mathrm{Btu} / \mathrm{h} \cdot \mathrm{ft}^{2} \bullet \circ \mathrm{F}\right)\end{array}$ & $\begin{array}{c}\text { Basement } \\
\left(\mathrm{Btu} / \mathrm{h} \bullet \mathrm{ft} \bullet^{\circ} \mathrm{F}\right)\end{array}$ \\
\hline $\begin{array}{l}\text { State Average } \\
\text { (Nonelectric) }\end{array}$ & 0.033 & 0.179 & 0.767 & 0.05 & 1.509 \\
\hline $\begin{array}{l}\text { State Average } \\
\text { (Electric) }\end{array}$ & 0.033 & 0.119 & 0.767 & 0.05 & 1.509 \\
\hline MEC Average & 0.026 & 0.127 & 0.764 & 0.05 & 1.228 \\
\hline
\end{tabular}

Tables RI.4, RI.5, and RI.6 show the state nonelectric and electric code and the 1992 MEC envelope requirements. 
Table RI.4. Rhode Island State Nonelectric Code Envelope Requirements

\begin{tabular}{||l|c|}
\hline Ceiling U-Value & 0.033 \\
\hline Wall U-Value & 0.080 \\
\hline Window U-Value & 0.650 \\
\hline Door U-Value & 0.650 \\
\hline Floor U-Value & 0.050 \\
\hline Basement Wall R-Value & 11 \\
\hline Basement Depth & 4 \\
\hline Slab R-Value & 10 \\
\hline Slab Depth & 2 \\
\hline \hline
\end{tabular}

Table RI.5. Rhode Island State Electric Code Envelope Requirements

\begin{tabular}{||l|c||}
\hline Ceiling U-Value & 0.033 \\
\hline Wall U-Value & 0.050 \\
\hline Window U-Value & 0.400 \\
\hline Door U-Value & 0.650 \\
\hline Floor U-Value & 0.050 \\
\hline Basement Wall R-Value & 11 \\
\hline Basement Depth & 4 \\
\hline Slab R-Value & 10 \\
\hline Slab Depth & 2 \\
\hline \hline
\end{tabular}


Table RI.6. 1992 MEC Envelope Requirements for Rhode Island

\begin{tabular}{|l|c|c|c|c|c|c||}
\hline & $\begin{array}{c}\text { Ceiling } \\
\text { U-Value }\end{array}$ & $\begin{array}{c}\text { Wall } \\
\text { U-Value }\end{array}$ & $\begin{array}{c}\text { Floor } \\
\text { U-Value }\end{array}$ & $\begin{array}{c}\text { Basement } \\
\text { U-Value }\end{array}$ & $\begin{array}{c}\text { Slab } \\
\text { R-Value }\end{array}$ & $\begin{array}{c}\text { Slab } \\
\text { Depth }\end{array}$ \\
\hline Providence & 0.0264 & 0.127 & 0.05 & 0.097 & 4.9 & 2 \\
\hline Woonsocket & 0.0264 & 0.127 & 0.05 & 0.097 & 4.9 & 2 \\
\hline
\end{tabular}

Table RI.7 shows the design information and housing starts for each of the cities used in the analysis.

Table RI.7. Design Information and Housing Starts for Rhode Island

\begin{tabular}{|l|c|c|c||}
\hline & HDD & $\begin{array}{c}\text { Design } \\
\text { Temperature }\end{array}$ & $\begin{array}{c}\text { Housing } \\
\text { Starts }\end{array}$ \\
\hline Providence & 5,909 & 9 & 2,562 \\
\hline Woonsocket & 5,909 & 9 & 16 \\
\hline
\end{tabular}




\section{South Carolina}

The South Carolina 1993 Building Energy Efficiency Standard Act is the state residential energy code for South Carolina. The South Carolina code applies only to those areas that have adopted the code. At present, about 27 out of 46 counties have adopted the state code.

Section 2, subsection (d) of the state code gives prescriptive requirements, which must be met for compliance for one- and two-family dwellings. These requirements are in addition to the requirements set forth in subsection (a). Subsection (a) references Appendix E of the "current" edition of the Southern Building Code Congress International (SBCCI) Standard Building Code. The Standard Building Code allows the use of ANSI/ASHRAE/IES Standard 90A-1980 (ASHRAE 1980) for compliance. Because the prescriptive requirements are more stringent than the ANSI/ASHRAE/IES Standard 90A-1980 requirements, the prescriptive requirements in subsection (d) take precedents and were reviewed.

Subsection (d) of the state code has two sets of prescriptive R-value thermal envelope requirements. The first set gives $\mathrm{R}$-value requirements applicable to all new one- and two-family dwellings. The second set of requirements are lower and may be used by builders to "facilitate the affordability of purchases of housing," provided the builder discloses the information to the buyer. Door U-value requirements are not given in the state code, so a U-value of 0.60 was assumed for the analysis. An overall envelope U-value comparison was performed. The state code requires double-pane or storm windows. For the analysis, the windows were assumed to be double-pane aluminum windows with a U-value of 0.72 .

Table SC. 1 shows the average overall envelope U-values for the state code and the $1992 \mathrm{MEC}$ (CABO 1992) for both compliance paths. The average overall U-value for the state code is greater than the overall MEC U-value for the "affordability" path. The average overall U-value for the state code for the more stringent path is slightly lower than the overall MEC U-value. For the state code to meet the 1992 MEC requirements, the least restrictive compliance path (i.e., the "affordability" path) must meet the 1992 MEC requirements. Because this path does not meet these requirements, the South Carolina code does not meet the $1992 \mathrm{MEC}$ requirements for one- and two-family dwellings. 
Table SC.1. Average Overall Envelope U-Values for South Carolina

\begin{tabular}{||l|c|}
\hline & $\mathrm{U}_{0}$ \\
\hline State Average (Affordable) & 0.113 \\
& $(9 \%$ above MEC avg.) \\
\hline State Average (Standard) & 0.103 \\
& $(0.6 \%$ below MEC avg.) \\
\hline MEC Average & 0.104 \\
\hline
\end{tabular}

Tables SC. 2 and SC. 3 show a more detailed comparison of the state code to the $1992 \mathrm{MEC}$ by the type of foundation insulation used and by envelope component. Table SC. 2 also shows combined Uvalues, which are the overall envelope U-values based on foundation type, averaged and weighted by the proportion of homes in the state with the given foundation type (percentages shown in parentheses). Table SC. 3 shows the state average U-value for walls, ceilings, and floors over unheated spaces and the state average F-value for slab and basement walls.

Table SC.2. Overall Envelope U-Values by Foundation Type for South Carolina

\begin{tabular}{||l|c|c|c|c|}
\hline & Slab (29\%) & $\begin{array}{c}\text { Floor Over Unheated } \\
\text { Space (70\%) }\end{array}$ & $\begin{array}{c}\text { Basement } \\
\text { Wall (2\%) }\end{array}$ & Combined \\
\hline State Average (Affordable) & 0.120 & 0.107 & 0.136 & 0.113 \\
\hline State Average (Standard) & 0.116 & 0.095 & 0.132 & 0.103 \\
\hline MEC Average & 0.111 & 0.099 & 0.101 & 0.103 \\
\hline
\end{tabular}

Table SC.3. Average Envelope Component U-Values or F-Values for South Carolina

\begin{tabular}{||l|c|c|c|c|c||}
\hline & $\begin{array}{c}\text { Ceiling } \\
\left(\mathrm{Btu} / \mathrm{h} \cdot \mathrm{ft}^{2} \bullet \circ \mathrm{F}\right)\end{array}$ & $\begin{array}{c}\text { Wall } \\
\left(\mathrm{Btu} / \mathrm{h} \cdot \mathrm{ft}^{2} \bullet \circ \mathrm{F}\right)\end{array}$ & $\begin{array}{c}\text { Slab } \\
\left(\mathrm{Btu} / \mathrm{h} \bullet \mathrm{ft} \bullet{ }^{\circ} \mathrm{F}\right)\end{array}$ & $\begin{array}{c}\text { Floor } \\
\left(\mathrm{Btu} / \mathrm{h} \bullet \mathrm{ft}^{2} \bullet \circ \mathrm{F}\right)\end{array}$ & $\begin{array}{c}\text { Basement } \\
\left(\mathrm{Btu} / \mathrm{h} \bullet \mathrm{ft} \bullet{ }^{\circ} \mathrm{F}\right)\end{array}$ \\
\hline $\begin{array}{l}\text { State Average } \\
\text { (Affordable) }\end{array}$ & 0.051 & 0.183 & 1.042 & 0.072 & 2.584 \\
\hline $\begin{array}{l}\text { State Average } \\
\text { (Standard) }\end{array}$ & 0.035 & 0.183 & 1.042 & 0.047 & 2.584 \\
\hline MEC Average & 0.042 & 0.179 & 0.879 & 0.058 & 1.405 \\
\hline (a) Includes windows and doors.
\end{tabular}


Tables SC. 4 and SC.5 show the envelope requirements for the state code and for the 1992 MEC.

Table SC.4. South Carolina State Code Envelope Requirements

\begin{tabular}{||l|c|c|c|c|c|c|c||}
\hline & $\begin{array}{c}\text { Ceiling } \\
\text { R-Value }\end{array}$ & $\begin{array}{c}\text { Wall } \\
\text { R-Value }\end{array}$ & $\begin{array}{c}\text { Window } \\
\text { U-Value }\end{array}$ & $\begin{array}{c}\text { Door } \\
\text { U-Value }\end{array}$ & $\begin{array}{c}\text { Floor } \\
\text { R-Value }\end{array}$ & $\begin{array}{c}\text { Basement Wall } \\
\text { R-Value }\end{array}$ & $\begin{array}{c}\text { Slab } \\
\text { R-Value }\end{array}$ \\
\hline $\begin{array}{l}\text { South Carolina } \\
\text { (Strict) }\end{array}$ & 30 & 13 & 0.72 & 0.6 & 19 & 0 & 0 \\
\hline $\begin{array}{l}\text { South Carolina } \\
\text { (Affordable) }\end{array}$ & 19 & 13 & 0.72 & 0.6 & 11 & 0 & 0 \\
\hline
\end{tabular}

Table SC.5. 1992 MEC Envelope Requirements for South Carolina

\begin{tabular}{|l|c|c|c|c|c|c||}
\hline & $\begin{array}{c}\text { Ceiling } \\
\text { U-Value }\end{array}$ & $\begin{array}{c}\text { Wall } \\
\text { U-Value }\end{array}$ & $\begin{array}{c}\text { Floor } \\
\text { U-Value }\end{array}$ & $\begin{array}{c}\text { Basement } \\
\text { U-Value }\end{array}$ & $\begin{array}{c}\text { Slab } \\
\text { R-Value }\end{array}$ & $\begin{array}{c}\text { Slab } \\
\text { Depth }\end{array}$ \\
\hline Aiken & 0.0433 & 0.185 & 0.07 & 0.149 & 0 & - \\
\hline Anderson & 0.0406 & 0.173 & 0.05 & 0.136 & 4 & 2 \\
\hline Charleston & 0.0445 & 0.194 & 0.07 & 0.155 & 0 & - \\
\hline Columbia & 0.0422 & 0.178 & 0.05 & 0.144 & 4 & 2 \\
\hline Conway & 0.0428 & 0.180 & 0.07 & 0.147 & 0 & - \\
\hline Florence & 0.0416 & 0.176 & 0.05 & 0.141 & 4 & 2 \\
\hline Georgetown & 0.0441 & 0.191 & 0.07 & 0.153 & 0 & - \\
\hline Greenville & 0.0392 & 0.168 & 0.05 & 0.129 & 4 & 2 \\
\hline Greenwood & 0.0394 & 0.169 & 0.05 & 0.130 & 4 & 2 \\
\hline Laurens & 0.0394 & 0.169 & 0.05 & 0.130 & 4 & 2 \\
\hline Orangeburg & 0.0424 & 0.179 & 0.05 & 0.145 & 4 & 2 \\
\hline Sumter & 0.0429 & 0.181 & 0.07 & 0.147 & 0 & - \\
\hline Union & 0.0383 & 0.165 & 0.05 & 0.125 & 4 & 2 \\
\hline \hline
\end{tabular}

Table SC. 6 shows the design information and housing starts for each of the cities used in the analysis. 
Table SC.6. Design Information and Housing Starts for South Carolina

\begin{tabular}{|l|c|c|c||}
\hline \hline & HDD & $\begin{array}{c}\text { Design } \\
\text { Temperature }\end{array}$ & $\begin{array}{c}\text { Housing } \\
\text { Starts }\end{array}$ \\
\hline Aiken & 2,387 & 25 & 768 \\
\hline Anderson & 2,960 & 23 & 1,421 \\
\hline Charleston & 2,146 & 27 & 3,730 \\
\hline Columbia & 2,632 & 24 & 3,688 \\
\hline Conway & 2,497 & 24 & 1,632 \\
\hline Florence & 2,741 & 25 & 122 \\
\hline Georgetown & 2,225 & 26 & 1,027 \\
\hline Greenville & 3,246 & 22 & 3,820 \\
\hline Greenwood & 3,198 & 22 & 346 \\
\hline Laurens & 3,215 & 18 & 253 \\
\hline Orangeburg & 2,584 & 24 & 292 \\
\hline Sumter & 2,481 & 25 & 703 \\
\hline Union & 3,438 & 17 & 1,129 \\
\hline \hline
\end{tabular}




\section{South Dakota}

The Model Code for Thermal and Lighting Efficiency in Building Construction is the state energy code for new residential construction for South Dakota. The state code has a single set of U-value thermal envelope requirements. An overall U-value comparison was performed. Requirements for basement walls are not explicitly given. Basement walls were treated as exterior walls so basement wall requirements are the same as above-grade wall requirements.

Table SD. 1 shows the average overall envelope U-value for the state code and the 1992 MEC (CABO 1992). The average overall state code U-value is higher than the average overall MEC U-value. Therefore, the South Dakota code does not meet the 1992 MEC requirements for one- and two-family dwellings.

Table SD.1. Average Overall Envelope U-Value for South Dakota

\begin{tabular}{|l|c|}
\hline & $\mathrm{U}_{0}$ \\
\hline State Average & 0.078 \\
& $(11 \%$ above MEC avg. $)$ \\
\hline MEC Average & 0.07 \\
\hline
\end{tabular}

Tables SD. 2 and SD.3 show a more detailed comparison of the state code to the $1992 \mathrm{MEC}$ by the type of foundation insulation used and by envelope component. Table SD.2 also shows combined Uvalues, which are the overall envelope $U$-values based on foundation type, averaged and weighted by the proportion of homes in the state with the given foundation type (percentages shown in parentheses). Table SD. 3 shows the state average U-value for walls, ceilings, and floors over unheated spaces and the state average $\mathrm{F}$-value for slab and basement walls.

Table SD.2. Average Overall Envelope U-Values by Foundation Type for South Dakota

\begin{tabular}{|l|c|c|c|c||}
\hline & Slab (0\%) & $\begin{array}{c}\text { Floor Over Unheated } \\
\text { Space (20\%) }\end{array}$ & $\begin{array}{c}\text { Basement } \\
\text { Wall (80\%) }\end{array}$ & Combined \\
\hline State Average & 0.081 & 0.078 & 0.078 & 0.078 \\
\hline MEC Average & 0.077 & 0.065 & 0.071 & 0.070 \\
\hline
\end{tabular}


Table SD.3. Average Envelope Component U-Values or F-Values for South Dakota

\begin{tabular}{|l|c|c|c|c|c||}
\hline & $\begin{array}{c}\text { Ceiling } \\
\left(\mathrm{Btu} / \mathrm{h} \bullet \mathrm{ft}^{2} \bullet{ }^{\circ} \mathrm{F}\right)\end{array}$ & $\begin{array}{c}\text { Wall } \\
\left(\mathrm{Btu} / \mathrm{h} \bullet \mathrm{ft}^{2} \bullet{ }^{\circ} \mathrm{F}\right)\end{array}$ & $\begin{array}{c}\text { Slab } \\
\left(\mathrm{Btu} / \mathrm{h} \bullet \mathrm{ft} \bullet{ }^{\circ} \mathrm{F}\right)\end{array}$ & $\begin{array}{c}\text { Floor } \\
\left(\mathrm{Btu} / \mathrm{h} \bullet \mathrm{ft}^{2} \bullet{ }^{\circ} \mathrm{F}\right)\end{array}$ & $\begin{array}{c}\text { Basement } \\
\left(\mathrm{Btu} / \mathrm{h} \bullet \mathrm{ft} \bullet{ }^{\circ} \mathrm{F}\right)\end{array}$ \\
\hline State Average & 0.026 & 0.12 & 0.804 & 0.08 & 1.335 \\
\hline MEC Average & 0.026 & 0.11 & 0.798 & 0.05 & 1.193 \\
\hline (a) Includes windows and doors.
\end{tabular}

Tables SD.4 and SD.5 show the envelope requirements for the state code and for the 1992 MEC.

Table SD.4. South Dakota State Code Envelope Requirements

\begin{tabular}{||l|c||}
\hline Ceiling U-Value & 0.026 \\
\hline Gross Wall U-Value & 0.120 \\
\hline Floor U-Value & 0.080 \\
\hline Basement Wall R-Value & 6.5 \\
\hline Basement Depth & 8 \\
\hline Slab R-Value & 5 \\
\hline Slab Depth & 2 \\
\hline
\end{tabular}


Table SD.5. 1992 MEC Envelope Requirements for South Dakota

\begin{tabular}{||l|c|c|c|c|c|c||}
\hline & $\begin{array}{c}\text { Ceiling } \\
\text { U-Value }\end{array}$ & $\begin{array}{c}\text { Wall } \\
\text { U-Value }\end{array}$ & $\begin{array}{c}\text { Floor } \\
\text { U-Value }\end{array}$ & $\begin{array}{c}\text { Basement } \\
\text { U-Value }\end{array}$ & $\begin{array}{c}\text { Slab } \\
\text { R-Value }\end{array}$ & $\begin{array}{c}\text { Slab } \\
\text { Depth }\end{array}$ \\
\hline Aberdeen & 0.026 & 0.11 & 0.05 & 0.085 & 6.7 & 4 \\
\hline Brookings & 0.026 & 0.11 & 0.05 & 0.081 & 6.8 & 4 \\
\hline Huron & 0.026 & 0.11 & 0.05 & 0.091 & 6.4 & 4 \\
\hline Mitchell & 0.026 & 0.11 & 0.05 & 0.093 & 5.9 & 4 \\
\hline Pierre & 0.026 & 0.11 & 0.05 & 0.092 & 6.1 & 4 \\
\hline Rapid City & 0.026 & 0.11 & 0.05 & 0.093 & 5.9 & 4 \\
\hline Sioux Falls & 0.026 & 0.11 & 0.05 & 0.092 & 6.3 & 4 \\
\hline Watertown & 0.026 & 0.11 & 0.05 & 0.070 & 6.9 & 4 \\
\hline Yankton & 0.026 & 0.11 & 0.05 & 0.093 & 6.0 & 4 \\
\hline
\end{tabular}

Table SD.6 shows the design information and housing starts for each of the cities used in the analysis.

Table SD.6. Design Information and Housing Starts for South Dakota

\begin{tabular}{|l|c|c|c||}
\hline & HDD & $\begin{array}{c}\text { Design } \\
\text { Temperature }\end{array}$ & $\begin{array}{c}\text { Housing } \\
\text { Starts }\end{array}$ \\
\hline Aberdeen & 8,577 & -15 & 78 \\
\hline Brookings & 8,653 & -13 & 167 \\
\hline Huron & 8,109 & -14 & 63 \\
\hline Mitchell & 7,397 & -10 & 403 \\
\hline Pierre & 7,580 & -10 & 124 \\
\hline Rapid City & 7,308 & -7 & 591 \\
\hline Sioux Falls & 7,890 & -11 & 1,107 \\
\hline Watertown & 8,826 & -15 & 231 \\
\hline Yankton & 7,480 & -7 & 123 \\
\hline
\end{tabular}




\section{Tennessee}

The Tennessee Code is the mandatory state building code for Tennessee. The state code adopts by. reference the 1992 MEC (CABO 1992) without amendments. Therefore, the Tennessee code meets the 1992 MEC requirements for one- and two-family dwellings. 


\section{Texas}

Texas has not adopted a state residential energy code. Therefore, Texas does not meet the 1992 MEC (CABO 1992) requirements for one- and two-family dwellings. 


\section{Utah}

The Uniform Building Code and the State of Utah Amendments contain the mandatory state energy code requirements for new residential construction for Utah. The state adopts by reference the International Conference of Building Officials (ICBO) 1991 Uniform Building Code, including Appendix 53 (ICBO 1991). Appendix 53 adopts the 1989 MEC without amendments (CABO 1989). Because the 1989 MEC and the 1992 MEC (CABO 1992) are nearly the same, the state code meets the 1992 MEC requirements for one- and two-family. 


\section{Vermont}

Act 250 governs the energy conservation criteria for new construction in Vermont. Approximately one-third of single-family homes and two-thirds of multifamily homes must go through the Act 250 process to get a building permit. Act 250 states that, "A permit will be granted when it has been demonstrated by the applicant that, in addition to all other applicable criteria, the planning and design of the subdivision or development reflect the principles of energy conservation and incorporate the best available technology for efficient use of the recovery of energy." The state is divided into nine regions, with commissions established in each region who are given the power to issue permits. Specific envelope requirements are not given by Act 250 . Each commission establishes its own energy requirements for single-family construction and evaluates housing projects on a case-by-case basis. Because housing projects are evaluated on a case-by-case basis, the Vermont code was classified as indeterminate.

The Vermont Department of Public Service has provided a prescriptive list of envelope recommendations to builders of single-family homes to help them when submitting an Act 250 application. This prescriptive list of recommendations was evaluated for compliance with the 1992 MEC (CABO 1992). An overall U-value comparison was performed. Perimeter slab insulation depth requirements are not specified, so a depth of $2 \mathrm{ft}$ was assumed for the analysis.

Table VT. 1 shows the average overall envelope U-value for the state's recommendations and the MEC. The average overall U-value for the state is the same as the overall MEC U-value. Therefore, the Vermont code's recommended prescriptive path marginally meets the $1992 \mathrm{MEC}$ requirements for oneand two-family dwellings.

Table VT.1. Average Overall Envelope U-Value for Vermont

\begin{tabular}{|l|c|}
\hline & $\mathrm{U}_{0}$ \\
\hline State Average & $\begin{array}{c}0.064 \\
(2 \% \text { below MEC })\end{array}$ \\
\hline MEC Average & 0.065 \\
\hline
\end{tabular}

Tables VT.2 and VT.3 show a more detailed comparison of the state's recommendations to the 1992 MEC by the type of foundation insulation used and by envelope component. Table VT.2 also shows combined U-values, which are the overall envelope U-values based on foundation type, averaged and weighted by the proportion of homes in the state with the given foundation type (percentages shown in parentheses). Table VT.3 shows the state average U-value for walls, ceilings, and floors over unheated spaces and the state average F-value for slab and basement walls. 
Table VT.2. Average Overall Envelope U-Values by Foundation Type for Vermont

\begin{tabular}{||l|c|c|c|c||}
\hline & Slab (2\%) & $\begin{array}{c}\text { Floor Over Unheated } \\
\text { Space (98\%) }\end{array}$ & $\begin{array}{c}\text { Basement } \\
\text { Wall (0\%) }\end{array}$ & Combined \\
\hline State Average & 0.075 & 0.064 & 0.070 & 0.064 \\
\hline MEC Average & 0.077 & 0.065 & 0.071 & 0.065 \\
\hline
\end{tabular}

Table VT.3. Average Envelope Component U-Values or F-Values for Vermont

\begin{tabular}{|l|c|c|c|c|c||}
\hline \hline & $\begin{array}{c}\text { Ceiling } \\
\left(\mathrm{Btu} / \mathrm{h} \bullet \mathrm{ft}^{2} \bullet{ }^{\circ} \mathrm{F}\right)\end{array}$ & $\begin{array}{c}\text { Wall } \\
\left(\mathrm{Btu} / \mathrm{h} \bullet \mathrm{ft}^{2} \bullet{ }^{\circ} \mathrm{F}\right)\end{array}$ & $\begin{array}{c}\text { Slab } \\
\left(\mathrm{Btu} / \mathrm{h} \bullet \mathrm{ft} \bullet{ }^{\circ} \mathrm{F}\right)\end{array}$ & $\begin{array}{c}\text { Floor } \\
\left(\mathrm{Btu} / \mathrm{h} \bullet \mathrm{ft}^{2} \bullet{ }^{\circ} \mathrm{F}\right)\end{array}$ & $\begin{array}{c}\text { Basement } \\
\left(\mathrm{Btu} / \mathrm{h} \bullet \mathrm{ft} \bullet{ }^{\circ} \mathrm{F}\right)\end{array}$ \\
\hline State Average & 0.030 & 0.105 & 0.767 & 0.047 & 1.182 \\
\hline MEC Average & 0.026 & 0.110 & 0.796 & 0.050 & 1.208 \\
\hline (a) Includes windows and doors.
\end{tabular}

Tables VT.4 and VT.5 show the envelope requirements for the state code and for the 1992 MEC.

Table VT.4. Vermont State Code Envelope Requirements

\begin{tabular}{||l|c||}
\hline Ceiling R-Value & 38 \\
\hline Wall R-Value & 19 \\
\hline Window U-Value & 0.40 \\
\hline Door R-Value & 10 \\
\hline Floor R-Value & 19 \\
\hline Basement Wall R-Value & 10 \\
\hline Basement Depth & 8 \\
\hline Slab R-Value & 10 \\
\hline Slab Depth & 2 \\
\hline
\end{tabular}

A. 115 
Table VT.5. 1992 MEC Envelope Requirements for Vermont

\begin{tabular}{||l|c|c|c|c|c|c|}
\hline & $\begin{array}{c}\text { Ceiling } \\
\text { U-Value }\end{array}$ & $\begin{array}{c}\text { Wall } \\
\text { U-Value }\end{array}$ & $\begin{array}{c}\text { Floor } \\
\text { U-Value }\end{array}$ & $\begin{array}{c}\text { Basement } \\
\text { U-Value }\end{array}$ & $\begin{array}{c}\text { Slab } \\
\text { R-Value }\end{array}$ & $\begin{array}{c}\text { Slab } \\
\text { Depth }\end{array}$ \\
\hline Burlington & 0.026 & 0.11 & 0.05 & 0.091 & 6.3 & 4 \\
\hline Rutland & 0.026 & 0.11 & 0.05 & 0.093 & 5.8 & 4 \\
\hline
\end{tabular}

Table VT.6 shows the design information and housing starts for each of the cities used in the analysis.

Table VT.6. Design Information and Housing Starts for Vermont

\begin{tabular}{|l|c|c|c|}
\hline & HDD & $\begin{array}{c}\text { Design } \\
\text { Temperature }\end{array}$ & $\begin{array}{c}\text { Housing } \\
\text { Starts }\end{array}$ \\
\hline Burlington & 7,956 & -7 & 1,832 \\
\hline Rutland & 7,158 & -8 & 380 \\
\hline
\end{tabular}




\section{Virginia}

The Virginia Uniform Statewide Building Code is the mandatory state building code for Virginia. The state code adopts by reference the 1993 MEC without amendments (CABO 1993). Therefore, Virginia meets the 1992 MEC (CABO 1992) requirements for one- and two-family and multifamily dwellings. 


\section{Washington}

The Washington State Energy Code is the mandatory state energy code for new residential construction for Washington. The state code divides the state into two regions and gives separate requirements for electric and nonelectric homes. Compliance may be achieved through a systems analysis approach or by a component performance approach. These methods are assumed to result in approximately equivalent energy use. The component performance approach was used for this comparison. The component performance approach gives several prescriptive R-value paths for compliance, which are assumed to result in approximately equivalent energy use. The state code reference case was used for the comparison. Basement wall requirements differ depending on the placement of the insulation-interior versus exterior. For the analysis, the basement wall insulation was assumed to be placed on the interior of the wall. An overall U-value comparison was performed for the state, with the U-values from the two regions averaged and weighted by housing starts.

Tables WA.1 and WA. 2 show the average overall envelope U-values for the state code and the 1992 MEC (CABO 1992) for electric and nonelectric homes. The average overall state nonelectric code is higher than the average overall MEC U-value. Therefore, the Washington nonelectric code does not meet the 1992 MEC requirements for one- and two-family dwellings. The average overall U-value for the state electric code is lower than the average overall MEC U-value. Therefore, the Washington electric code meets the 1992 MEC requirements for one- and two-family dwellings.

Table WA.1. Average Overall Nonelectric Code Envelope U-Values for Regions of Washington

\begin{tabular}{|c|c|c||}
\hline Region & $\mathrm{U}_{\mathrm{o}}$ & Housing Starts (\%) \\
\hline 1 & 0.083 & 90 \\
\hline 2 & 0.075 & 10 \\
\hline State Average & 0.082 & \\
& $(7 \%$ above MEC avg.) & \\
\hline MEC Average & 0.077 & \\
\hline
\end{tabular}


Table WA.2. Average Overall Electric Code Envelope U-Values for Regions of Washington

\begin{tabular}{|c|c|c|}
\hline Region & $\mathrm{U}_{\mathrm{o}}$ & Housing Starts (\%) \\
\hline 1 & 0.062 & 90 \\
\hline 2 & 0.058 & 10 \\
\hline State Average & 0.061 & \\
$\cdots$ & $(20 \%$ below MEC avg.) & \\
\hline MEC Average & 0.077 & \\
\hline
\end{tabular}

Tables WA.3, WA.4, WA.5, and WA.6 show a more detailed comparison of the state code to the 1992 MEC by the type of foundation insulation used and by envelope component. Tables WA. 3 and WA.4 also show combined U-values, which are the overall envelope U-values based on foundation type, averaged and weighted by the proportion of homes in the state with the given foundation type (percentages shown in parentheses). Tables WA.3 and WA.4 show the state average U-value for walls, ceilings, and floors over unheated spaces and the state average F-value for slab and basement walls.

Table WA.3. Average Overall Nonelectric Envelope U-Values by Foundation Type for Washington

\begin{tabular}{|c|c|c|c|c||}
\hline Region & Slab (4\%) & $\begin{array}{c}\text { Floor Over Unheated } \\
\text { Space (85\%) }\end{array}$ & $\begin{array}{c}\text { Basement Wall } \\
(11 \%)\end{array}$ & Combined \\
\hline 1 & 0.094 & 0.083 & 0.080 & 0.083 \\
\hline 2 & 0.090 & 0.074 & 0.077 & 0.075 \\
\hline State Average & 0.093 & 0.082 & 0.080 & 0.082 \\
\hline MEC Average & 0.087 & 0.076 & 0.081 & 0.077 \\
\hline
\end{tabular}

Table WA.4. Average Overall Electric Code Envelope U-Values by Foundation Type for Washington

\begin{tabular}{|c|c|c|c|c||}
\hline Region & Slab (4\%) & $\begin{array}{c}\text { Floor over Unheated } \\
\text { Space (85\%) }\end{array}$ & $\begin{array}{c}\text { Basement Wall } \\
(11 \%)\end{array}$ & Combined \\
\hline 1 & 0.076 & 0.060 & 0.066 & 0.062 \\
\hline 2 & 0.073 & 0.057 & 0.063 & 0.058 \\
\hline State Average & 0.076 & 0.060 & 0.066 & 0.061 \\
\hline MEC Average & 0.087 & 0.076 & 0.081 & 0.077 \\
\hline
\end{tabular}


Table WA.5. Average Nonelectric Code Envelope Component U-Values or F-Values for Washington

\begin{tabular}{|c|c|c|c|c|c||}
\hline Region & $\begin{array}{c}\text { Wall } \\
\left(\mathrm{Btu} / \mathrm{h} \bullet \mathrm{ft}^{2} \bullet^{\circ} \mathrm{F}\right)\end{array}$ & $\begin{array}{c}\text { Ceiling } \\
\left(\mathrm{Btu} / \mathrm{h} \bullet \mathrm{ft}^{2} \bullet^{\circ} \mathrm{F}\right)\end{array}$ & $\begin{array}{c}\text { Floor } \\
\left(\mathrm{Btu} / \mathrm{h} \bullet \mathrm{ft}^{2} \bullet{ }^{\circ} \mathrm{F}\right)\end{array}$ & $\begin{array}{c}\text { Slab } \\
\left(\mathrm{Btu} / \mathrm{h} \bullet \mathrm{ft} \bullet^{\circ} \mathrm{F}\right)\end{array}$ & $\begin{array}{c}\text { Basement } \\
\left(\mathrm{Btu} / \mathrm{h} \bullet \mathrm{ft} \bullet^{\circ} \mathrm{F}\right)\end{array}$ \\
\hline 1 & 0.150 & 0.035 & 0.047 & 0.767 & 1.008 \\
\hline 2 & 0.143 & 0.030 & 0.033 & 0.767 & 1.008 \\
\hline State Average & 0.149 & 0.035 & 0.046 & 0.767 & 1.008 \\
\hline MEC Average & 0.136 & 0.030 & 0.050 & 0.769 & 1.234 \\
\hline (a) Includes windows and doors.
\end{tabular}

Table WA.6. Average Electric Code Envelope Component U-Values or F-Values for Washington

\begin{tabular}{|c|c|c|c|c|c||}
\hline Region & $\begin{array}{c}\text { Wall (a) } \\
\left(\mathrm{Btu} / \mathrm{h} \bullet \mathrm{ft}^{2} \bullet{ }^{\circ} \mathrm{F}\right)\end{array}$ & $\begin{array}{c}\text { Ceiling } \\
\left(\mathrm{Btu} / \mathrm{h} \bullet \mathrm{ft}^{2} \bullet{ }^{\circ} \mathrm{F}\right)\end{array}$ & $\begin{array}{c}\text { Floor } \\
\left(\mathrm{Btu} / \mathrm{h} \bullet \mathrm{ft}^{2} \bullet{ }^{\circ} \mathrm{F}\right)\end{array}$ & $\begin{array}{c}\text { Slab } \\
\left(\mathrm{Btu} / \mathrm{h} \bullet \mathrm{ft} \bullet^{\circ} \mathrm{F}\right)\end{array}$ & $\begin{array}{c}\text { Basement } \\
\left(\mathrm{Btu} / \mathrm{h} \bullet \mathrm{ft} \bullet^{\circ} \mathrm{F}\right)\end{array}$ \\
\hline 1 & 0.108 & 0.03 & 0.033 & 0.767 & 1.008 \\
\hline 2 & 0.099 & 0.03 & 0.033 & 0.767 & 0.996 \\
\hline $\begin{array}{c}\text { State } \\
\text { Average }\end{array}$ & 0.107 & 0.03 & 0.033 & 0.767 & 1.007 \\
\hline $\begin{array}{c}\text { MEC } \\
\text { Average }\end{array}$ & 0.136 & 0.03 & 0.050 & 0.769 & 1.234 \\
\hline (a) Includes windows and doors.
\end{tabular}

The results of the duct analysis showed duct losses associated with the Washington code requirements to be $2.7 \%$ compared to duct losses of $3 \%$ associated with the $1992 \mathrm{MEC}$ requirements.

Tables WA.7, WA.8, and WA.9 show the state nonelectric and electric code and the 1992 MEC envelope requirements.

Table WA.7. Washington State Nonelectric Code Envelope Requirements

\begin{tabular}{||c|c|c|c|c|c|c|c|c|c||}
\hline Region & $\begin{array}{c}\text { Ceiling } \\
\text { R-Value }\end{array}$ & $\begin{array}{c}\text { Wall } \\
\text { R-Value }\end{array}$ & $\begin{array}{c}\text { Window } \\
\text { U-Value }\end{array}$ & $\begin{array}{c}\text { Door } \\
\text { U-Value }\end{array}$ & $\begin{array}{c}\text { Floor } \\
\text { R-Value }\end{array}$ & $\begin{array}{c}\text { Basement } \\
\text { Wall } \\
\text { R-Value }\end{array}$ & $\begin{array}{c}\text { Basement } \\
\text { Depth }\end{array}$ & $\begin{array}{c}\text { Slab } \\
\text { R-Value }\end{array}$ & $\begin{array}{c}\text { Slab } \\
\text { Depth }\end{array}$ \\
\hline 1 & 30 & 19 & 0.65 & 0.4 & 19 & 19 & 8 & 10 & 2 \\
\hline 2 & 38 & 19 & 0.60 & 0.4 & 30 & 19 & 8 & 10 & 2 \\
\hline
\end{tabular}


Table WA.8. Washington State Electric Code Envelope Requirements

\begin{tabular}{||c|c|c|c|c|c|c|c|c|c||}
\hline \hline Region & $\begin{array}{c}\text { Ceiling } \\
\text { R-Value }\end{array}$ & $\begin{array}{c}\text { Wall } \\
\text { R-Value }\end{array}$ & $\begin{array}{c}\text { Window } \\
\text { U-Value }\end{array}$ & $\begin{array}{c}\text { Door } \\
\text { U-Value }\end{array}$ & $\begin{array}{c}\text { Floor } \\
\text { R-Value }\end{array}$ & $\begin{array}{c}\text { Basement } \\
\text { Wall } \\
\text { R-Value }\end{array}$ & $\begin{array}{c}\text { Basement } \\
\text { Depth }\end{array}$ & $\begin{array}{c}\text { Slab } \\
\text { R-Value }\end{array}$ & $\begin{array}{c}\text { Slab } \\
\text { Depth }\end{array}$ \\
\hline 1 & 38 & 19 & 0.40 & 0.20 & 30 & 19 & 8 & 10 & 2 \\
\hline 2 & 38 & 19 & 0.40 & 0.20 & 30 & 21 & 8 & 10 & 2 \\
\hline
\end{tabular}

Table WA.9. 1992 MEC Envelope Requirements for Washington

\begin{tabular}{|l|c|c|c|c|c|c||}
\hline & $\begin{array}{c}\text { Ceiling } \\
\text { U-Value }\end{array}$ & $\begin{array}{c}\text { Wall } \\
\text { U-Value }\end{array}$ & $\begin{array}{c}\text { Floor } \\
\text { U-Value }\end{array}$ & $\begin{array}{c}\text { Basement } \\
\text { U-Value }\end{array}$ & $\begin{array}{c}\text { Slab } \\
\text { R-Value }\end{array}$ & $\begin{array}{c}\text { Slab } \\
\text { Depth }\end{array}$ \\
\hline Aberdeen & 0.0293 & 0.136 & 0.05 & 0.098 & 4.5 & 2 \\
\hline Bellingham & 0.0277 & 0.131 & 0.05 & 0.097 & 4.8 & 2 \\
\hline Bremerton & 0.0299 & 0.138 & 0.05 & 0.098 & 4.5 & 2 \\
\hline Centralia & 0.0304 & 0.140 & 0.05 & 0.099 & 4.4 & 2 \\
\hline Everett & 0.0291 & 0.136 & 0.05 & 0.098 & 4.6 & 2 \\
\hline Kennewick & 0.0315 & 0.143 & 0.05 & 0.099 & 4.2 & 2 \\
\hline Kent & 0.0304 & 0.140 & 0.05 & 0.099 & 4.4 & 2 \\
\hline Longview & 0.0305 & 0.140 & 0.05 & 0.099 & 4.4 & 2 \\
\hline Moses Lake & 0.0260 & 0.121 & 0.05 & 0.096 & 5.2 & 4 \\
\hline Olympia & 0.0274 & 0.130 & 0.05 & 0.097 & 4.8 & 2 \\
\hline Port Angeles & 0.0274 & 0.130 & 0.05 & 0.097 & 4.8 & 2 \\
\hline Pullman & 0.0260 & 0.114 & 0.05 & 0.094 & 5.5 & 4 \\
\hline Puyallup & 0.0301 & 0.139 & 0.05 & 0.098 & 4.4 & 2 \\
\hline Richland & 0.0322 & 0.146 & 0.05 & 0.100 & 4.1 & 2 \\
\hline Seattle & 0.0302 & 0.139 & 0.05 & 0.098 & 4.4 & 2 \\
\hline Spokane & 0.0260 & 0.112 & 0.05 & 0.094 & 5.6 & 4 \\
\hline Tacoma & 0.0318 & 0.144 & 0.05 & 0.099 & 4.2 & 2 \\
\hline Vancouver & 0.0307 & 0.141 & 0.05 & 0.099 & 4.4 & 2 \\
\hline Walla Walla & 0.0305 & 0.140 & 0.05 & 0.099 & 4.4 & 2 \\
\hline Wenatchee & 0.0274 & 0.130 & 0.05 & 0.097 & 4.8 & 2 \\
\hline Yakima & 0.0260 & 0.125 & 0.05 & 0.096 & 5.0 & 4 \\
\hline & & & & & & \\
\hline
\end{tabular}


Table WA.10 shows the design information and housing starts for each of the cities used in the analysis.

Table WA.10. Design Information and Housing Starts for Washington

\begin{tabular}{||l|c|c|c|c||}
\hline & HDD & $\begin{array}{c}\text { Design } \\
\text { Temperature }\end{array}$ & $\begin{array}{c}\text { Housing } \\
\text { Starts }\end{array}$ & Region \\
\hline Aberdeen & 5,321 & 28 & 0 & 1 \\
\hline Bellingham & 5,640 & 15 & 1,615 & 1 \\
\hline Bremerton & 5,194 & 25 & 2,398 & 1 \\
\hline Centralia & 5,083 & 14 & 270 & 1 \\
\hline Everett & 5,354 & 25 & 4,396 & 1 \\
\hline Kennewick & 4,854 & 11 & 774 & 1 \\
\hline Kent & 5,075 & 17 & 389 & 1 \\
\hline Longview & 5,063 & 24 & 391 & 1 \\
\hline Moses Lake & 6,296 & 7 & 153 & 2 \\
\hline Olympia & 5,710 & 22 & 2,336 & 1 \\
\hline Port Angeles & 5,714 & 27 & 759 & 1 \\
\hline Pullman & 6,757 & 3 & 0 & 2 \\
\hline Puyallup & 5,145 & 18 & 297 & 1 \\
\hline Richland & 4,710 & 10 & 215 & 1 \\
\hline Seattle & 5,122 & 26 & 10,165 & 1 \\
\hline Spokane & 6,885 & 2 & 3,486 & 2 \\
\hline Tacoma & 4,795 & 24 & 5,950 & 1 \\
\hline Vancouver & 5,031 & 13 & 4,584 & 1 \\
\hline Walla Walla & 5,057 & 7 & 251 & 1 \\
\hline Wenatchee & 5,698 & 11 & 482 & 2 \\
\hline Yakima & 6,035 & 5 & 996 & 1 \\
\hline \hline
\end{tabular}




\section{West Virginia}

The building code for West Virginia adopts by reference the 1990 BOCA National Building Code (BOCA 1990a). The West Virginia code applies only to municipalities that have adopted it. The 1990 BOCA National Building Code allows for compliance using ANSI/ASHRAE/IES Standard 90A-1980 (ASHRAE 1980) or the 1989 MEC (CABO 1989). ANSI/ASHRAE/IES Standard 90A-1980 is substantially less stringent than the 1992 MEC (CABO 1992) (see Section 2.3 of this report). Therefore, the West Virginia code does not meet the 1992 MEC requirements for one- and two-family dwellings. 


\section{Wisconsin}

The Wisconsin Administrative Code, Department of Industry, Labor and Human Relations Chs. ILHR 20-25 is the mandatory state building code for new residential construction for Wisconsin. The state code has separate electric and nonelectric requirements. The code gives a set of prescriptive U-value requirements that apply to the whole state.

An overall envelope U-value comparison was performed. Table WI.1 shows the average overall envelope U-values for the state code and the 1992 MEC (CABO 1992) for electric and nonelectric homes. The average overall U-value for the state nonelectric code is higher than the average overall MEC U-value. Therefore, the Wisconsin nonelectric code does not meet the 1992 MEC requirements for oneand two-family dwellings. The average overall $U$-value for the state electric code is lower than the average overall MEC U-value. Therefore, the Wisconsin electric code meets the $1992 \mathrm{MEC}$ requirements for one- and two-family dwellings.

Table WI.1. Average Overall Envelope U-Values for Wisconsin

\begin{tabular}{||l|c|}
\hline & $\mathrm{U}_{\mathrm{o}}$ \\
\hline State Average (nonelectric) & $\begin{array}{c}0.087 \\
(27 \% \text { above MEC avg.) }\end{array}$ \\
\hline State Average (electric) & 0.057 \\
& $(17 \%$ below MEC avg.) \\
\hline MEC Average & 0.069 \\
\hline
\end{tabular}

Tables WI. 2 and WI.3 show a more detailed comparison of the state code to the 1992 MEC by the type of foundation insulation used and by envelope component. Table WI.2 also shows combined Uvalues, which are the overall envelope U-values based on foundation type, averaged and weighted by the proportion of homes in the state with the given foundation type (percentages shown in parentheses). Table WI.3 shows the state average U-value for walls, ceilings, and floors over unheated spaces and the state average F-value for slab and basement walls. 
Table WI.2. Average Overall Envelope U-Values by Foundation Type for Wisconsin

\begin{tabular}{|l|c|c|c|c|}
\hline & Slab (2\%) & $\begin{array}{c}\text { Floor Over Unheated } \\
\text { Space (54\%) }\end{array}$ & $\begin{array}{c}\text { Basement } \\
\text { Wall (45\%) }\end{array}$ & Combined \\
\hline State Average (Nonelectric) & 0.078 & 0.082 & 0.092 & 0.087 \\
\hline State Average (Electric) & 0.060 & 0.054 & 0.060 & 0.057 \\
\hline MEC Average & 0.077 & 0.065 & 0.071 & 0.069 \\
\hline
\end{tabular}

Table WI.3. Average Envelope Component U-Values or F-Values for Wisconsin

\begin{tabular}{|l|c|c|c|c|c||}
\hline & $\begin{array}{c}\text { Ceiling } \\
\left(\mathrm{Btu} / \mathrm{h} \bullet \mathrm{ft}^{2} \bullet{ }^{\circ} \mathrm{F}\right)\end{array}$ & $\begin{array}{c}\text { Wall } \\
\left(\mathrm{Btu} / \mathrm{h} \bullet \mathrm{ft}^{2} \bullet{ }^{\circ} \mathrm{F}\right)\end{array}$ & $\begin{array}{c}\text { Slab } \\
\left(\mathrm{Btu} / \mathrm{h} \bullet \mathrm{ft} \bullet{ }^{\circ} \mathrm{F}\right)\end{array}$ & $\begin{array}{c}\text { Floor } \\
\left(\mathrm{Btu} / \mathrm{h} \bullet \mathrm{ft}^{2} \bullet{ }^{\circ} \mathrm{F}\right)\end{array}$ & $\begin{array}{c}\text { Basement } \\
\left(\mathrm{Btu} / \mathrm{h} \bullet \mathrm{ft} \bullet{ }^{\circ} \mathrm{F}\right)\end{array}$ \\
\hline $\begin{array}{l}\text { State Average } \\
\text { (Nonelectric) }\end{array}$ & 0.029 & 0.12 & 0.692 & 0.090 & 1.837 \\
\hline $\begin{array}{l}\text { State Average } \\
\text { (Electric) }\end{array}$ & 0.020 & 0.08 & 0.684 & 0.055 & 1.182 \\
\hline MEC Average & 0.026 & 0.11 & 0.798 & 0.050 & 1.202 \\
\hline (a) Includes windows and doors. & & & & \\
\hline
\end{tabular}

The results of the duct analysis showed duct losses associated with the Wisconsin code requirements to be $4.8 \%$ compared to duct losses of $3.0 \%$ associated with the $1992 \mathrm{MEC}$ requirements.

Tables WI.4, WI.5, and WI.6 show the state nonelectric and electric code and the 1992 MEC envelope requirements. 
Table WI.4. Wisconsin State Nonelectric Code Envelope Requirements

\begin{tabular}{||l|c||}
\hline Ceiling U-Value & 0.029 \\
\hline Gross Wall U-Value & 0.120 \\
\hline Floor U-Value & 0.090 \\
\hline Basement Wall R-Value & 5 \\
\hline Basement Depth & 3 \\
\hline Slab R-Value & 9 \\
\hline Slab Depth & 4 \\
\hline
\end{tabular}

Table WI.5. Wisconsin State Electric Code Envelope Requirements

\begin{tabular}{||l|c|}
\hline Ceiling U-Value & 0.020 \\
\hline Gross Wall U-Value & 0.080 \\
\hline Floor U-Value & 0.050 \\
\hline Basement Wall R-Value & 10 \\
\hline Basement Depth & 8 \\
\hline Slab R-Value & 10 \\
\hline Slab Depth & 4 \\
\hline
\end{tabular}

Table WI.6. 1992 MEC Envelope Requirements for Wisconsin

\begin{tabular}{||l|c|c|c|c|c|c||}
\hline & $\begin{array}{c}\text { Ceiling } \\
\text { U-Value }\end{array}$ & $\begin{array}{c}\text { Wall } \\
\text { U-Value }\end{array}$ & $\begin{array}{c}\text { Floor } \\
\text { U-Value }\end{array}$ & $\begin{array}{c}\text { Basement } \\
\text { U-Value }\end{array}$ & $\begin{array}{c}\text { Slab } \\
\text { R-Value }\end{array}$ & $\begin{array}{c}\text { Slab } \\
\text { Depth }\end{array}$ \\
\hline Appleton & 0.026 & 0.110 & 0.05 & 0.092 & 6.2 & 4 \\
\hline Beloit & 0.026 & 0.116 & 0.05 & 0.095 & 5.4 & 4 \\
\hline Eau Claire & 0.026 & 0.110 & 0.05 & 0.090 & 6.6 & 4 \\
\hline Fond du Lac & 0.026 & 0.110 & 0.05 & 0.092 & 6.0 & 4 \\
\hline Germantown & 0.026 & 0.110 & 0.05 & 0.092 & 6.0 & 4 \\
\hline Green Bay & 0.026 & 0.110 & 0.05 & 0.091 & 6.4 & 4 \\
\hline Janesville & 0.026 & 0.114 & 0.05 & 0.094 & 5.5 & 4 \\
\hline Kenosha & 0.026 & 0.110 & 0.05 & 0.094 & 5.7 & 4 \\
\hline
\end{tabular}


Table WI.6. (contd)

\begin{tabular}{||l|c|c|c|c|c|c||}
\hline & $\begin{array}{c}\text { Ceiling } \\
\text { U-Value }\end{array}$ & $\begin{array}{c}\text { Wall } \\
\text { U-Value }\end{array}$ & $\begin{array}{c}\text { Floor } \\
\text { U-Value }\end{array}$ & $\begin{array}{c}\text { Basement } \\
\text { U-Value }\end{array}$ & $\begin{array}{c}\text { Slab } \\
\text { R-Value }\end{array}$ & $\begin{array}{c}\text { Slab } \\
\text { Depth }\end{array}$ \\
\hline LaCrosse & 0.026 & 0.110 & 0.05 & 0.092 & 6.0 & 4 \\
\hline Madison & 0.026 & 0.110 & 0.05 & 0.092 & 6.1 & 4 \\
\hline Manitowoc & 0.026 & 0.110 & 0.05 & 0.093 & 6.0 & 4 \\
\hline Marinette & 0.026 & 0.110 & 0.05 & 0.093 & 6.0 & 4 \\
\hline Marshfield & 0.026 & 0.110 & 0.05 & 0.088 & 6.7 & 4 \\
\hline Milwaukee & 0.026 & 0.110 & 0.05 & 0.093 & 5.9 & 4 \\
\hline Oshkosh & 0.026 & 0.110 & 0.05 & 0.092 & 6.1 & 4 \\
\hline Racine & 0.026 & 0.111 & 0.05 & 0.094 & 5.6 & 4 \\
\hline Sheboygan & 0.026 & 0.110 & 0.05 & 0.093 & 5.8 & 4 \\
\hline Stevens Point & 0.026 & 0.110 & 0.05 & 0.091 & 6.4 & 4 \\
\hline Superior & 0.026 & 0.110 & 0.05 & 0.060 & 7.2 & 4 \\
\hline Two Rivers & 0.026 & 0.110 & 0.05 & 0.092 & 6.2 & 4 \\
\hline Watertown & 0.026 & 0.110 & 0.05 & 0.093 & 5.8 & 4 \\
\hline Waukesha & 0.026 & 0.110 & 0.05 & 0.093 & 5.8 & 4 \\
\hline Wausau & 0.026 & 0.110 & 0.05 & 0.086 & 6.7 & 4 \\
\hline West Allis & 0.026 & 0.112 & 0.05 & 0.094 & 5.6 & 4 \\
\hline Whitewater & 0.026 & 0.111 & 0.05 & 0.094 & 5.6 & 4 \\
\hline Wisconsin Rapids & 0.026 & 0.110 & 0.05 & 0.091 & 6.5 & 4 \\
\hline
\end{tabular}

Table WI.7 shows the design information and housing starts for each of the cities used in the analysis.

Table WI.7. Design Information and Housing Starts for Wisconsin

\begin{tabular}{|l|c|c|c||}
\hline \hline & HDD & $\begin{array}{c}\text { Design } \\
\text { Temperature }\end{array}$ & $\begin{array}{c}\text { Housing } \\
\text { Starts }\end{array}$ \\
\hline Appleton & 7,729 & -9 & 556 \\
\hline Beloit & 6,616 & -3 & 95 \\
\hline Eau Claire & 8,466 & -11 & 1,462 \\
\hline Fond du Lac & 7,570 & -8 & 472 \\
\hline
\end{tabular}

A. 127 
Table WI.7. (contd)

\begin{tabular}{||l|c|c|c||}
\hline & HDD & $\begin{array}{c}\text { Design } \\
\text { Temperature }\end{array}$ & $\begin{array}{c}\text { Housing } \\
\text { Starts }\end{array}$ \\
\hline Germantown & 7,528 & -8 & 1,071 \\
\hline Green Bay & 8,146 & -9 & 2,467 \\
\hline Janesville & 6,765 & 7 & 714 \\
\hline Kenosha & 7,089 & 4 & 1,091 \\
\hline LaCrosse & 7,544 & -9 & 601 \\
\hline Madison & 7,643 & -7 & 5,021 \\
\hline Manitowoc & 7,520 & -7 & 464 \\
\hline Marinette & 7,455 & -11 & 18 \\
\hline Marshfield & 8,536 & -8 & 140 \\
\hline Milwaukee & 7,327 & -4 & 2,771 \\
\hline Oshkosh & 7,692 & -7 & 1,986 \\
\hline Racine & 6,920 & -2 & 1,311 \\
\hline Sheboygan & 7,234 & -6 & 276 \\
\hline Stevens Point & 8,108 & -11 & 1,059 \\
\hline Superior & 9,381 & -18 & 1,545 \\
\hline Two Rivers & 7,802 & 1 & 866 \\
\hline Watertown & 7,168 & -8 & 495 \\
\hline Waukesha & 7,196 & -5 & 4,413 \\
\hline Wausau & 8,569 & -12 & 1,399 \\
\hline West Allis & 6,855 & 1 & 289 \\
\hline Whitewater & 6,925 & 5 & 779 \\
\hline Wisconsin Rapids & 8,286 & -12 & 293 \\
\hline \hline
\end{tabular}




\section{Wyoming}

The Wyoming State Status, chapter 9 section 35-9-106, gives the Council on Fire Prevention, Electrical Safety and Energy Efficiency in Buildings, the power to adopt rules and regulations recommending minimum standards for the conservation of energy in new residential buildings for Wyoming. The standards are required to result in energy savings equal to those achievable under ANSIIASHRAEIIES Standard 90-75 (ASHRAE 1975) or Chapter 53 of the International Conference of Building Officials (ICBO) Uniform Building Code. The council currently recommends Chapter 53, "Energy Conservation in New Building Construction," of the Uniform Building Code as the minimum standards for the conservation of energy in new residential buildings. Chapter 53 of the 1991 Uniform Building Code (ICBO 1991) references the 1989 MEC (CABO 1993). Therefore, the Wyoming code meets the 1992 MEC (CABO 1992) for one- and two-family dwellings but the standard is not mandatory. 


\section{A.1 References}

American Society of Heating, Refrigerating and Air-Conditioning Engineers, Inc. (ASHRAE). 1975. ANSI/ASHRAE/IES Standard 90-75, "Energy Conservation in New Building Design." ASHRAE, New York.

American Society of Heating, Refrigerating and Air-Conditioning Engineers, Inc. (ASHRAE). 1980. ANSI/ASHRAE/IES Standard 90A-1980, "Energy Conservation in New Building Design." ASHRAE, New York.

American Society of Heating, Refrigerating and Air-Conditioning Engineers, Inc. (ASHRAE). 1993. 1993 ASHRAE Handbook Fundamentals. Atlanta, Georgia.

Building Officials and Code Administrators International, Inc. (BOCA). 1990a. BOCA National Building Code. Country Club Hills, Illinois.

Building Officials and Code Administrators International, Inc. (BOCA). 1990b. BOCA National Mechanical Code. Country Club Hills, Illinois.

Building Officials and Code Administrators International, Inc. (BOCA). 1993. BOCA National Building Code. Country Club Hills, Illinois.

Council of American Building Officials (CABO). 1983. Model Energy Code; 1983 Edition. Falls Church, Virginia.

Council of American Building Officials (CABO). 1986. Model Energy Code; 1986 Edition. Falls Church, Virginia.

Council of American Building Officials (CABO). 1989. Model Energy Code; 1989 Edition. Falls Church, Virginia.

Council of American Building Officials (CABO). 1992. Model Energy Code; 1992 Edition. Falls Church, Virginia.

Council of American Building Officials (CABO). 1993. Model Energy Code; 1993 Edition. Falls Church, Virginia.

International Conference of Building Officials (ICBO). 1991. Uniform Building Code. Whittier, Califomia.

International Conference of Building Officials (ICBO). Updated annually. Uniform Building Code. Whittier, California. 
Lortz, V. B., and Z. T. Taylor. 1989. Recommendations for Energy Conservation Standards for New Residential Buildings. Volume 2: Automated Residential Energy Standard - User's Guide - Version 1.1. PNL-6878 Vol. 2, Pacific Northwest Laboratory, Richland, Washington.

Southern Building Code Congress International (SBCCI). Updated every three years. Standard Building Code. Birmingham, Alabama. 
Appendix B

Envelope Component U-Value Calculations 


\section{Appendix B}

\section{Envelope Component U-Value Calculations}

The 1992 Model Energy Code (MEC) generally presents envelope component requirements in overall U-values, which account for all details of envelope component construction (CABO 1992). Most state code prescriptive requirement packages show requirements in R-values of insulating materials because insulation $R$-values are readily available and no calculations are needed. To convert insulation $\mathrm{R}$-values to overall component $\mathrm{U}$-values, assumptions have to be made about the typical construction of the envelope components. Note that construction materials and techniques often vary from those described below.

The general equation for calculating heat flow through building envelope components is

$$
\mathrm{U}_{0}=\left[\mathrm{U}_{1} \times \text { Area }_{1}+\mathrm{U}_{2} \times \text { Area }_{2}+\ldots\right] /\left[\text { Area }_{1}+\text { Area }_{2}+\ldots\right]
$$

where the subscripts identify areas of uniform construction; e.g., Area 1 is the area between the framing and Area 2 is the area of the framing. The U-value is the inverse of the sum of all the material $\mathrm{R}$-values for each area and includes the insulating value of surface air films. Equation (B.1) is sufficiently accurate unless any of the construction material is-highly conductive, such as steel framing.

For envelope components with wood frame construction, Equation (B.2) becomes

$$
\mathrm{U}_{\mathrm{o}}=\text { Area studs } / \sum \mathrm{R} \text { (framing path) }+ \text { Area insulation } / \sum \mathrm{R} \text { (insulation path) }
$$

\section{B.1 Ceilings}

Two common types of ceilings are ceilings separated by an attic space and ceilings without attics (vaulted or cathedral). Because of construction differences, the overall U-values for these two ceiling types are slightly different for equal insulation R-values. For this analysis, the home was assumed to have a ceiling with an attic.

For ceilings with attics, our analysis assumed blown fiberglass insulation, although batt insulation in ceilings is also common. Blown insulation has less insulating value per inch than batt insulation (ASHRAE 1989). Insulation was assumed to cover the ceiling joists so that "voids" were negligible. 
Equivalent batt and blown insulation $R$-values achieve similar overall U-values, so the assumptions of insulation type have little effect. Ceiling joists or rafters were assumed to be at 24 -in. on center (O.C.), occupying $7 \%$ of the ceiling area (ASHRAE 1989).

The U-value calculation for ceilings with attics assumes using either a standard truss or raisedtruss construction. The American Society of Heating, Refrigerating and Air-Conditioning Engineers, Inc. (ASHRAE) recommends an attic ventilation rate of $0.5 \mathrm{~cm} / \mathrm{ft}^{2}$ of ceiling area to control moisture (ASHRAE 1989). For ceilings with attics, we assumed a fully vented attic with a still-air film resistance above the insulation and a 1-in. space between the insulation and the roof near the eaves for ventilation. A prefabricated truss system was assumed because these systems are most common in new residential construction (Anderson and McKeever 1991). For truss members, $2 \times 4$ framing (DeCristoforo 1987) and a roof slope of $4 / 12$ were assumed. Table B.1 shows the heat flow paths for ceilings with attics, and Equation (B.3) uses these results to compute the final U-value of the ceiling assembly.

Table B.1. Heat Flow Paths for Ceilings with Attics

\begin{tabular}{|c|c|c|}
\hline Description & R-Value at Joists & $\begin{array}{l}\mathrm{R} \text {-Value at } \\
\text { Insulation }\end{array}$ \\
\hline Percentage of Ceiling Area & $7 \%$ & $93 \%$ \\
\hline Attic Air Film & 0.61 & 0.61 \\
\hline Insulation & Rij & Ric \\
\hline Joists & 4.38 & -- \\
\hline 1/2-in. Drywall & 0.45 & 0.45 \\
\hline Inside Air Film & 0.61 & 0.61 \\
\hline Total Path R-Value & $6.05+\mathrm{Rij}$ & $1.67+\mathrm{Ric}$ \\
\hline
\end{tabular}

$$
\text { Ceiling U-Value }=\frac{0.07}{6.05+\text { Rij }}+\frac{0.93}{1.67+\text { Ric }}
$$

where $\quad \mathrm{Rij}=$ the effective overall $\mathrm{R}$-value of the insulation above the joists as computed by Equation (B.5)

$\mathrm{Ric}=$ the effective overall R-value of the cavity insulation as computed by Equation (B.4). 
Equations (B.4) and (B.5) account for the limited space for insulation at the eaves, which can be alleviated by raising the trusses 12 in. For a standard truss, the space available at the eaves was assumed to be 3.86 in. For a raised truss, the space available at the eaves was assumed to be $15.86 \mathrm{in}$. (3.86 in. +12.0 in.). Equation (B.4) shows how the effective overall R-value of the ceiling cavity insulation (Ric) is calculated. The effective insulation $R$-value is equal to the rated $R$-value if adequate space exists for the full insulation thickness at the eaves. Equation (B.5) shows how the effective overall R-value of insulation is calculated for the insulation above the ceiling joists (Rij). Equation (B.5) is the same as Equation (B.4), except 3.5 in. is subtracted from the full insulation depth to account for the insulation displaced by the $2 \times 4$ joist. If the truss is not raised, the height of the insulation at the eaves cannot be greater than 0.36 in. (3.86 in. - 3.5 in.). If the truss is raised, the height of the insulation above the eaves cannot be greater than $12.36 \mathrm{in}$. (15.86 in. -3.5 in.). Table B.2 shows some $U$-values for ceilings with attics as calculated by this methodology.

$$
\text { Ric }=\frac{\text { Ric }_{\text {nominal }}}{1+\left(\frac{\text { yic }_{\text {full }}}{\text { roof height }}\right) \ln \left(\frac{\text { yic }_{\text {full }}}{\text { yic }_{\text {eave }}}\right)-\left(\frac{\text { yic }_{\text {full }}-\text { yic }_{\text {eave }}}{\text { roof height }}\right)}
$$

$$
\begin{aligned}
& \text { where } \quad \mathrm{Ric}_{\text {nominal }}=\text { the rated } \mathrm{R} \text {-value of the cavity insulation }\left(\mathrm{R}_{\text {insulation }}\right) \\
& \text { yic }_{\text {full }}=\text { the full thickness in inches of the cavity insulation } \\
& =R_{\text {insulation }} / 2.5 \text { (for blown fiberglass) } \\
& \text { yic } \text { eave }_{\text {a }}=\text { the thickness in inches of the cavity insulation at the eaves. The space } \\
& \text { available at the eaves is assumed to be } 3.86 \text { in. for a standard truss. If } \\
& \text { yic }_{\text {full }} \text { is greater than } 3.86 \text { in., yic }_{\text {eave }} \text { is set to } 3.86 \text { in. For a raised truss, the } \\
& \text { space available is assumed to be } 15.86 \mathrm{in} \text {. (3.86 in. }+12.0 \mathrm{in} \text {.). If } \mathrm{yic}_{\text {full }} \text { is } \\
& \text { greater than } 15.86 \text { in., yic eave } \text { is set to } 15.86 \mathrm{in} \text {. }
\end{aligned}
$$




$$
R i j=\frac{R \mathrm{ij}_{\text {nominal }}}{1+\left(\frac{y \mathrm{yj}_{\text {full }}}{\text { roof height }}\right) \ln \left(\frac{\mathrm{yij}}{\mathrm{yij}_{\text {full }}}\right)-\left(\frac{\mathrm{yij} \mathrm{full}_{\text {full }}-\mathrm{yij}_{\text {eave }}}{\text { roof height }}\right)}
$$

where $R i j_{\text {nominal }}=$ the $R$-value of the insulation above the joist, which is the rated insulation $R$-value $\left(R_{\text {insulation }}\right)$ minus the joist height (assumed to be 3.5 in.) times the conductivity (assumed to be $2.5 \mathrm{Btu} / \mathrm{h} \cdot \mathrm{fft}^{2}$ ):

$=R_{\text {insulation }}-(3.5 \times 2.5)$

yij $_{\text {full }} \quad=$ the full thickness of the insulation above the joist (in inches)

$=(\mathrm{R}$-value $/ 2.5)-3.5$

yij $_{\text {eave }} \quad=$ the thickness (in inches) of the insulation above the joists at the eaves. The space available at the eaves is assumed to be 0.36 in. for a standard truss ( $3.86 \mathrm{in.}-3.5 \mathrm{in}$.). If $\mathrm{y}_{\text {full }}$ is greater than $0.36 \mathrm{in}$., yijeave is set to $0.36 \mathrm{in}$. For a raised truss, the space available is assumed to be 12.36 in. (15.86 in. - $3.5 \mathrm{in.}$.). If yij $\mathrm{full}_{\text {full }}$ is greater than $12.36 \mathrm{in}$., $\mathrm{y}_{\text {eave }}$ is set to $12.36 \mathrm{in}$.

roof height $=$ the maximum height in inches at the center line of the house. A 56-in. height was assumed, which corresponds to a $28-\mathrm{ft}$ roof with a $33.3 \%$ slope.

Table B.2. U-Values for Ceilings with Attics

\begin{tabular}{|c|c|c|c||}
\hline Nominal R-Value & $\begin{array}{c}\text { Average Insulation } \\
\text { R-Value (Ric) }\end{array}$ & $\begin{array}{c}\text { Insulation R-Value } \\
\text { Above Joists (Rij) }\end{array}$ & $\begin{array}{c}\text { U-Value of Ceiling } \\
\text { Including Framing }\end{array}$ \\
\hline \hline 11 & 11 & 2.2 & 0.082 \\
\hline 19 & 18.5 & 9.2 & 0.051 \\
\hline 30 & 27.3 & 15.9 & 0.035 \\
\hline 38 & 32.5 & 19.1 & 0.030 \\
\hline $38+$ Raised Truss & 38.0 & 29.2 & 0.025 \\
\hline 49 & 38.0 & 22.2 & 0.026 \\
\hline $49+$ Raised Truss & 48.6 & 39.9 & 0.020 \\
\hline
\end{tabular}




\section{B.2 Walls}

This section describes the calculation of wall U-values, excluding windows and doors. Wall materials were assumed to be plywood siding, plywood and/or foam insulation sheathing on the exterior, batt insulation, wood framing, and 1/2-in. gypboard on the interior. Walls with rigid foam insulation were assumed to have plywood sheathing for $20 \%$ of the wall area to account for structural support at corners. Walls with insulation R-values equal to or less than R-15 were modeled as having $2 \times 4$ studs at 16-in. O.C. Walls with insulation $R$-values greater than $R-15$ were modeled as having $2 \times 6$ studs at 16-in. O.C.

Based on ASHRAE assumptions, the 16-in. O.C. translates to a framing fraction of $15 \%$ of the opaque wall area (ASHRAE 1989). Wall construction heat flow paths are shown in Table B.3. Equation (B.6) shows how opaque wall U-values are calculated.

Table B.3. Heat Flow Paths for Wood-Framed Walls

\begin{tabular}{||l|c|c||}
\hline \multicolumn{1}{|c|}{ Description } & R-Value at Studs & R-Value at Insulation \\
\hline \hline Percentage of Wall Area & $15 \%$ & $85 \%$ \\
\hline \hline Outside Air Film & 0.17 & 0.17 \\
\hline Plywood Siding & 0.59 & 0.59 \\
\hline Sheathing & $\mathrm{Rs}$ & $\mathrm{Rs}$ \\
\hline Wood Studs & $\mathrm{RW}$ & -- \\
\hline Insulation & -- & $\mathrm{Ri}$ \\
\hline 1/2-in. Gypboard & 0.45 & 0.45 \\
\hline Inside Air Film & 0.68 & 0.68 \\
\hline Total Path R-Value & $1.89+\mathrm{Rs}+\mathrm{Rw}$ & $1.89+\mathrm{Rs}+\mathrm{Ri}$ \\
\hline
\end{tabular}

$$
\begin{aligned}
\text { Wall U-Value }= & {\left[\frac{0.15}{1.89+\mathrm{Rs}+\mathrm{Rw}}+\frac{0.85}{1.89+\mathrm{Rs}+\mathrm{Ri}}\right] 0.80+} \\
& {\left[\frac{0.15}{2.72+\mathrm{Rw}}+\frac{0.85}{2.72+\mathrm{Ri}}\right] 0.20 }
\end{aligned}
$$


where $\quad R s=$ the R-value of the insulating sheathing. If no insulating sheathing is used, the sheathing is assumed to be plywood with an R-value of 0.83 . Only $80 \%$ of the net wall is assumed to be covered with insulating sheathing. The other $20 \%$ is assumed to be covered with plywood $(\mathrm{R}$-value $=0.83$ ).

$\mathrm{Rw}=$ the $\mathrm{R}$-value of the wood framing members. The R-value of the wood framing members was assumed to be R-4.38 for $2 \times 4$ construction and R-6.88 for $2 \times 6$ construction.

$\mathrm{Ri}=$ the rated $\mathrm{R}$-value of the cavity insulation.

\section{B.3 Floors Over Unheated Spaces}

Floors over unheated spaces were assumed to be constructed of batt insulation, wood framing, a 3/4-in. wood subfloor, and carpet with a rubber pad. The floor joists were modeled as $2 \times 10$ studs at 16-in. O.C. (DeCristoforo 1987) occupying 10\% of the floor area. The effective thickness of the joists for the thermal calculation was set equal to the thickness of the insulation. This thickness was used because heat flows directly out of the sides of the joists beyond the depth of the insulation. Table B.4 shows the heat flow paths for floors over unheated spaces, and Equation (B.7) uses these results to compute the final floor assembly U-value. Table B.5 shows some U-values for floors over unheated spaces as calculated by this methodology.

Table B.4. Heat Flow Paths for Floors Over Unheated Spaces

\begin{tabular}{||l|c|c||}
\hline \multicolumn{1}{|c|}{ Description } & $\begin{array}{c}\text { R-Value at } \\
\text { Joists }\end{array}$ & $\begin{array}{c}\text { R-Value at } \\
\text { Insulation }\end{array}$ \\
\hline \hline Percentage of Floor Area & $10 \%$ & $90 \%$ \\
\hline \hline Floor Air Film & 0.92 & 0.92 \\
\hline Insulation & -- & $\mathrm{Ri}$ \\
\hline Joists & $\mathrm{Rj}$ & -- \\
\hline Carpet and Pad & 2.17 & 2.17 \\
\hline Inside Air Film & 0.92 & 0.92 \\
\hline \multicolumn{1}{|c|}{ Total Path R-Value } & $4.01+\mathrm{Rj}$ & $4.01+\mathrm{Ri}$ \\
\hline
\end{tabular}




$$
\text { Floor U-Value }=\frac{0.1}{4.01+R j}+\frac{0.9}{4.01+R \dot{i}}
$$

where $\quad R j=$ the R-value of the wood joists, which was assumed to be 1.25 times the thickness of the cavity insulation. The thickness of the batt cavity insulation was assumed to be equal to the $R$-value of the insulation $\left(R_{\text {insulation }}\right.$ ) divided by 3.0 .

$=1.25 \times\left(\mathrm{R}_{\text {insulation }} / 3.0\right)$

$\mathrm{Ri}=$ the rated $\mathrm{R}$-value of the cavity insulation.

Table B.5. U-Values for Floors Over Unheated Spaces

\begin{tabular}{|c|c|}
\hline Batt R-Value & $\begin{array}{c}\text { U-Value of Floor } \\
\text { Including Framing }\end{array}$ \\
\hline 0 & 0.2494 \\
\hline 11 & 0.0719 \\
\hline 13 & 0.0648 \\
\hline 19 & 0.0478 \\
\hline 30 & 0.0328 \\
\hline
\end{tabular}

\section{B.4 References}

American Society of Heating, Refrigerating and Air-Conditioning Engineers, Inc. (ASHRAE). 1989. 1989 ASHRAE Handbook Fundamentals. Atlanta, Georgia.

Anderson, R. G., and D. B. McKeever. 1991. Wood Used in New Residential Construction in the United States. American Plywood Association, American Wood Council, National Forest Products Association, Southern Forest Products Association, Western Wood Products Association, and the Forest Service, U.S. Department of Agriculture, Washington, D.C.

Council of American Building Officials (CABO). 1992. Model Energy Code; 1992 Edition. Falls Church, Virginia.

DeCristoforo, R. J. 1987. Housebuilding-A Do-It-Yourself Guide. Sterling Publishing Co., Inc., New York. 


\section{Distribution}

No. of

Copies

Offsite

12 DOE/Office of Scientific and Technical Information

J. Boulin

Office of Codes and Standards

CE-43

U.S. Department of Energy

1000 Independence Avenue SW

Washington, D.C. 20585

S. Turchen

Office of Codes and Standards

CE-43

U.S. Department of Energy

1000 Independence Avenue SW

Washington, D.C. 20585

S. Walder

Office of Codes and Standards

CE-43

U.S. Department of Energy

1000 Independence Avenue SW

Washington, D.C. 20585

W. Freeborne MS 8136

U.S. Department of Housing and Urban

Development

451 - 7th Street S.W.

Room 8238

Washington, D.C. 20410

S. Hodges

Farmers Home Administration

14th \& Independence Avenue SW

Washington, D.C. 20250
No. of

Copies

Offsite

R. Burton

National Association of Home

Builders

15th \& "M" Streets N.W.

Washington, D.C. 20005

S. Braun

North American Insulation

Manufacturers Association

44 Canal Center Plaza

Suite 310

Alexandria, VA 22314

R. Nixon

National Multi Housing Council

1850 "M" Street NW, Suite 540

Washington, D.C. 20036

Onsite

DOE Richland Operations Office

J. K. Schmitz K8-50

67 Pacific Northwest Laboratory

J. L. Carlson Program Files (55) K5-02

C. C. Conner

K5-16

D. R. Conover

WDC/9372

J. A. Johnson

K5-16

L. A. Klevgard

K5-20

R. G. Lucas

K5-16

Z. T. Taylor

K5-06

Publishing Coordination

K1-06

Technical Report Files (5)

Distr. 1 